Salinity of Surface Water in

The Lower Colorado River-

Salton Sea Area

GEOLOGICAL SURVEY PROFESSIONAL PAPER 486-E 



\section{Salinity of Surface Water in}

The Lower Colorado River-

\section{Salton Sea Area}

By BURDGE IRELAN

WATER RESOURCES OF LOWER COLORADO RIVER-SALTON SEA AREA

GEOLOGICAL SURVEY PROFESSIONAL PAPER 486-E

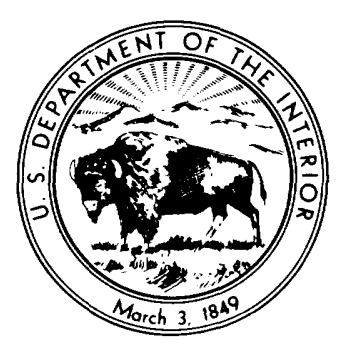

UNITED STATES GOVERNMENT PRINTING OFFICE, WASHINGTON : 1971 
UNITED STATES DEPARTMENT OF THE INTERIOR

ROGERS C. B. MORTON, Secretary

GEOLOGICAL SURVEY

William T. Pecora, Director

Library of Congress catalog-card No. 72-610761 


\section{CONTENTS}

\section{Abstract}

Introduction

General chemical characteristics of Colorado River water from Lees Ferry to Imperial Dam -...-....

Lees Ferry

Grand Canyon

Hoover Dam

Lake Havasu

Imperial Dam

Mineral burden of the lower Colorado River, 1926-65

Analysis of dissolved-solids loads

Analysis of ionic loads

Average annual ionic burden of the Colorado River

Ionic budget of the Colorado River from Lees Ferry to

Imperial Dam, 1961-65

Lees Ferry

Paria River

Little Colorado River

Blue Springs

Unmeasured inflow from Lees Ferry to Grand Canyon

Grand Canyon

Bright Angel Creek

$\begin{array}{rc}\text { Page } & \text { Ionic budget of the Colorado River from Lees Ferry to } \\ 2 & \text { Imperial Dam, 1961-65-Continued } \\ 2 & \text { Tapeats Creek } \\ 4 & \text { Havasu Creek } \\ 6 & \text { Unirgin River } \\ 8 & \text { Hoover Dam } \\ 11 & \text { Chemical changes in Lake Mead } \\ 12 & \text { Bill Williams River } \\ 12 & \text { Chemical changes in Lakes Mohave and Havasu } \\ 13 & \text { Diversion to Colorado River aqueduct } \\ 15 & \text { Parker Dam to Imperial Dam } \\ 20 & \text { Ionic accounting of principal irrigation areas above } \\ 22 & \text { Imperial Dam } \\ 23 & \text { General characteristics of Colorado River water below } \\ 23 & \text { Imperial Dam } \\ 24 & \text { Ionic budgets for the Colorado River below Imperial } \\ 25 & \text { Dam and Gila River } \\ 25 & \text { Quality of surface water in the Salton Sea basin in } \\ 25 & \text { California }\end{array}$

Page

E26

26

26

26

26

27

27

27

28

28

29

34

36

39

40

\section{ILLUSTRATIONS}

FIGURE 1. Map showing principal features of the lower Colorado River-Salton Sea area

2. Graph showing annual streamflow and annual weighted-average concentration of dissolved-solids, Colorado River at Grand Canyon, 1926-65

3. Graph showing annual weighted-average concentration of dissolved solids, sulfate, bicarbonate, and chloride, Colorado River at Grand Canyon, 1926-65

4. Histograms of weighted-average concentration of dissolved solids, Colorado River near Grand Canyon and below Hoover Dam, 1935-62

5. Graph showing approximate relations of dissolved-solids load and concentration to flow of Colorado River near Grand Canyon, 1926-62

6. Mass diagram of cumulative dissolved-solids load for Colorado River at.Grand Canyon, 1926-65

7. Double-mass diagram of cumulative dissolved-solids load to cumulative streamflow, Colorado River at Grand Canyon, 1926-65

8. Comparative differential mass diagram for streamflow and dissolved-solids load, Colorado River at Grand Canyon, 1926-62

9. Graphs showing approximate relations of annual ionic load of principal constituents to annual flow of Colorado River near Grand Canyon, 1926-62

10. Graphs showing progressive 5-year average ionic and dissolved-solids load, Colorado River near Grand Canyon and below Hoover Dam, 1935-65

11. Map showing principal features of the Wellton-Mohawk and Yuma areas

12. Map showing principal features of the Salton Sea area and vicinity 


\section{TABLES}

TABLE 1. Annual weighted-average concentration of Colorado River at Lees Ferry, Ariz.

2. Annual weighted-average concentration of Colorado River at Grand Canyon, Ariz.

3. Summary of weighted-average concentrations of dissolved solids, Colorado River at Grand Canyon, 1926-62

4. Annual weighted-average concentration of Colorado River below Hoover Dam, Ariz.-Nev.

5. Annual weighted-average concentration of Colorado River at Lake Havasu, Ariz.-Calif.

6. Annual weighted-average concentration of Colorado River at Imperial Dam, Ariz.-Calif.

7. Five-year summary of streamflow and ionic burden of lower Colorado River from Lees Ferry to Imperial

$$
\text { Dam-1941-65 }
$$

8. Forty-year summary of ionic burden of Colorado River at Grand Canyon by 5-year intervals, 1926-65 .

9. Averages of streamflow and ionic burden of Colorado River at Grand Canyon for different periods

10. Comparative computations of average annual streamflow and ionic burden of Colorado River at Lees Ferry

11. Representative analyses of tributary inflow to lower Colorado River between Lees Ferry and Imperial Dam

12. Average annual streamflow and ionic burden of the Colorado River, Lees Ferry to Imperial Dam, 1961-65

13. Average annual water use and ionic burden in irrigated areas, Parker Dam to Jnperial Dam, 1961-65

14. Representative analyses of surface water in Colorado River basin at and below Imperial Dam, 1966 water year

15. Streamflow and ionic burden of the Colorado River, Imperial Dam to south international boundary, 1966

16. Streamflow and ionic burden of the lower Gila River, Wellton-Mohawk area to mouth, 1966

17. Streamflow and ionic burden of inflow and outflow for combined Wellton-Mohawk and Yuma areas, 1966

18. Distribution of surface-water and dissolved-mineral gains and losses for combined Wellton-Mohawk and Yuma areas, 1966

19. Selected chemical analyses of surface water in Salton Sea basin 


\title{
SALINITY OF SURFACE WATER IN THE LOWER COLORADO RIVER-SALTON SEA AREA
}

\author{
By BURdge IrELAN
}

\begin{abstract}
This report summarizes records of salinity and computations of the mineral burden of the Colorado River and tributary surface inflow from Lees Ferry to the Mexican border and of streams in the adjacent Salton Sea basin.

The virgin salinity regimen of the Colorado River (that prior to upstream irrigation) is unknown, but was probably similar to the regimen observed during earlier years of sampling. Before closure of Hoover Dam, the salinity at points of record on the river varied rather substantially daily, seasonally, and annually and also varied moderately (generally increasing) with distance downstream. Observed dissolved-solids concentrations, which ranged between 200 and $1,800 \mathrm{mg} / 1$ (milligrams per liter) consisted mainly of calcium bicarbonate at lower concentration levels and mixed sulfate and chloride salts at higher concentration levels.

The chemical-quality record for the Colorado River at Grand Canyon indicates that the 40 -year weighted-average concentration is about $600 \mathrm{mg} / \mathrm{l}$. The long-time average at Lees Ferry has been moderately less. Recent storage and diversion projects above Lees Ferry have apparently caused small increases in annual weighted-average mineral concentrations, but these increases have been less than the differences between 10 -year weighted averages.

Since Lake Mead was formed, dissolved-solids concentrations in Colorado River water between Hoover and Imperial Dams have generally ranged between 600 and $900 \mathrm{mg} / \mathrm{l}$, with calcium sulfate always the dominant dissolved salt. Concentrations below Hoover Dam have been higher, on the average, than those at Grand Canyon mainly as a result of evaporation from the surface of Lake Mead and solution from its bed. The higher concentrations, however, have been partially offset by precipitation of calcium carbonate in the lake. Solution of minerals from the bed of the lake, although still considerable, appears to be substantially less than during the first years after its formation.

The annual mineral burden of the river varies markedly, but average burdens for periods of 5 or more years are fairly stable. Although most of this burden originates above Lees Ferry, rather large increments originate in the discharge of Blue Springs, which are on the Little Colorado River a short distance above its mouth, and in the Virgin River. Other

Lower Basin tributaries add much smaller increments to the river's mineral burden.

Low releases from Lake Powell during the first 2 years of impoundment caused a temporary rise in average salinity at Grand Canyon and contributed to later increases in the salinity of water in Lake Mead and in the Colorado River downstream from Hoover Dam.

Diversions to the California aqueduct increased substantially during 1961-65. This reduced the amount of river water available downstream from the diversion for dilution of slightly to moderately saline irrigation return flows from the Parker and Palo Verde Valleys and thereby caused higher average concentrations at Imperial Dam. Somewhat saline drain water from expanded irrigation in the Parker and Palo Verde Valleys also has contributed to the increased concentration at Imperial Dam.

Computations of gains and losses indicate that during recent years more mineral salts were removed from the Parker and Palo Verde Valleys in return flows than were brought into them in the irrigation water.

Dissolved-solids concentrations are now relatively constant at Imperial Dam because of upstream storage, but both the flow and the mineral burden of the Colorado River below the dam are greatly reduced by diversions to the All-American and Gila Gravity Carals. Thereafter, the salinity and mineral burden progressively increase as surface irrigation return flows and pumped ground water are discharged into the river.

During the last 30 years, flow of the Gila River above the Wellton-Mohawk area has usually been too small to affect materially the salinity and mineral burden of the Colorado River, although during the exceptional year 1966 it added some water of excellent quality to the irrigation supply. Ground water pumped to control water levels in the WelltonMohawk area and South Gila Valley has been much more saline than the applied irrigation water and has added substantially to the mineral burden of the lower Gila and Colorado Rivers, particularly since 1960 . A salinity problem in Mexico caused by expanded pumping of saline ground water in 1961 has been brought under control by drilling new wells, constructing a concrete-lined conveyance channel with controlled outlets, and management of the pumping according to the salinity of the individual well waters and irrigation requirements.
\end{abstract}


Colorado River water flows through the All-American Canal from Imperial Dam to Imperial and Coachella Valleys in the Salton Sea basin without material change in salinity. Both valleys contained areas with saline soils before they were irrigated, and early salinity problems developed, mainly because of inadequate drainage. Present drainage systems have been developed to the point where more dissolved minerals are removed from irrigated areas than are brought in by irrigation water.

The Alamo, New, and Whitewater Rivers, which drain to the Salton Sea, have differing water-quality characteristics. Some water suitable for irrigation appears to enter each stream as a result of present irrigation practices, and part of their flows possibly could be salvaged.

\section{INTRODUCTION}

The Colorado River is a major continental stream draining one-twelfth of the conterminous United States. The equitable division of its water among the seven basin states and Mexico has long been and remains difficult. The Colorado's flow is subject to provisions of an international treaty, interstate compacts, congressional acts, and court decrees. Today the river is a source of water for small cities within its basin, for great cities outside its basin, and for irrigation of large areas in and near its basin. The natural salinity (concentration of dissolved solids) of its water ranks among the highest of the great rivers of North America. Increasing salinity in the lower reaches has long been recognized as an almost inevitable result of increasing use of water from rivers flowing through arid lands. Yet, strangely, none of the legal documents dividing the flow of the Colorado River is concerned with its salinity.

The Colorado River is a mammoth transport system in which both water and dissolved-mineral salts continuously move downstream. The river flow is derived from many sources, each with individual chemical characteristics which blend in the river. The resulting changeable pattern of interrelated variations in concentration, composition, and mineral load ${ }^{1}$ constitutes the chemical regimen of the river, which has been investigated for this report.

Records of streamflow had been obtained at numerous points in the Colorado River basin for many years before the Geological Survey began an extended systematic sampling of the variations in mineral concentrations in the river water at Grand Canyon in August, 1925. Since then the Geological Survey has systematically sampled the lower river at one or more points every year. Some of the earlier quality-

\footnotetext{
1 Mineral load, as used in this report, refers to the total quantity of dissolved-mineral salts and silica transported by the river past a particular point in a specified time. The term is synonymous with "salt load" as used in many reports, but is preferred because "salt load" sometimes refers only to a single salt-sodium chloride.
}

of-water records, however, have never been summarized in the published reports of the Geological Survey. Other organizations also have sampled the river, some occasionally and some for extended periods.

Foreseeing the time when water in the Colorado River and the local ground water, which is largely derived from the river, together will not be sufficient to meet projected needs without careful management, the Geological Survey in 1960 began a comprehensive investigation of factors affecting the development and use of water in and adjacent to the lower Colorado River including the Salton Sea basin, which depends primarily on the Colorado River for water. This report, describing the quality of the surface water, is one of a series that constitutes an appraisal of the water resources of the lower Colorado River-Salton Sea area. It examines all available chemical-quality records of surface water in the study area to determine the chemical regimen of the river as related both to variations in ionic concentrations in the water and to mineral loads transported by the river.

A companion report by Hely (1969) describes the area considered in this report and the availability of its surface water, explains the division of the Colorado River drainage at compact point into Upper and Lower Basins, and also explains the reasons for making a hydrological appraisal of the area primarily served by the Colorado River water rather than appraising a limited part of the Colorado River basin by itself. Ground-water quality in the area is to be separately covered in several reports describing the occurrence and availability of ground water.

An earlier investigation by the Geological Survey (Iorns and others, 1965) describes the water resources of the Upper Colorado River Basin in detail and serves as a background for the Lower Basin study.

Figure 1 shows the location of the area considered by this study, indicates its principal subdivision, and shows the sites of the major dams and principal sampling points discussed in the report.

\section{GENERAL CHEMICAL CHARACTERISTICS OF COLORADO RIVER WATER FROM LEES FERRY TO IMPERIAL DAM}

The salinity of Colorado River water commonly has been described in terms of its dissolved-solids concentrations, or the concentrations of dominant ionic constituents, stated either separately or combined as salts. A single dominant combination of ions, however, has rarely been adequate to define the river-water composition. The natural (virgin) 


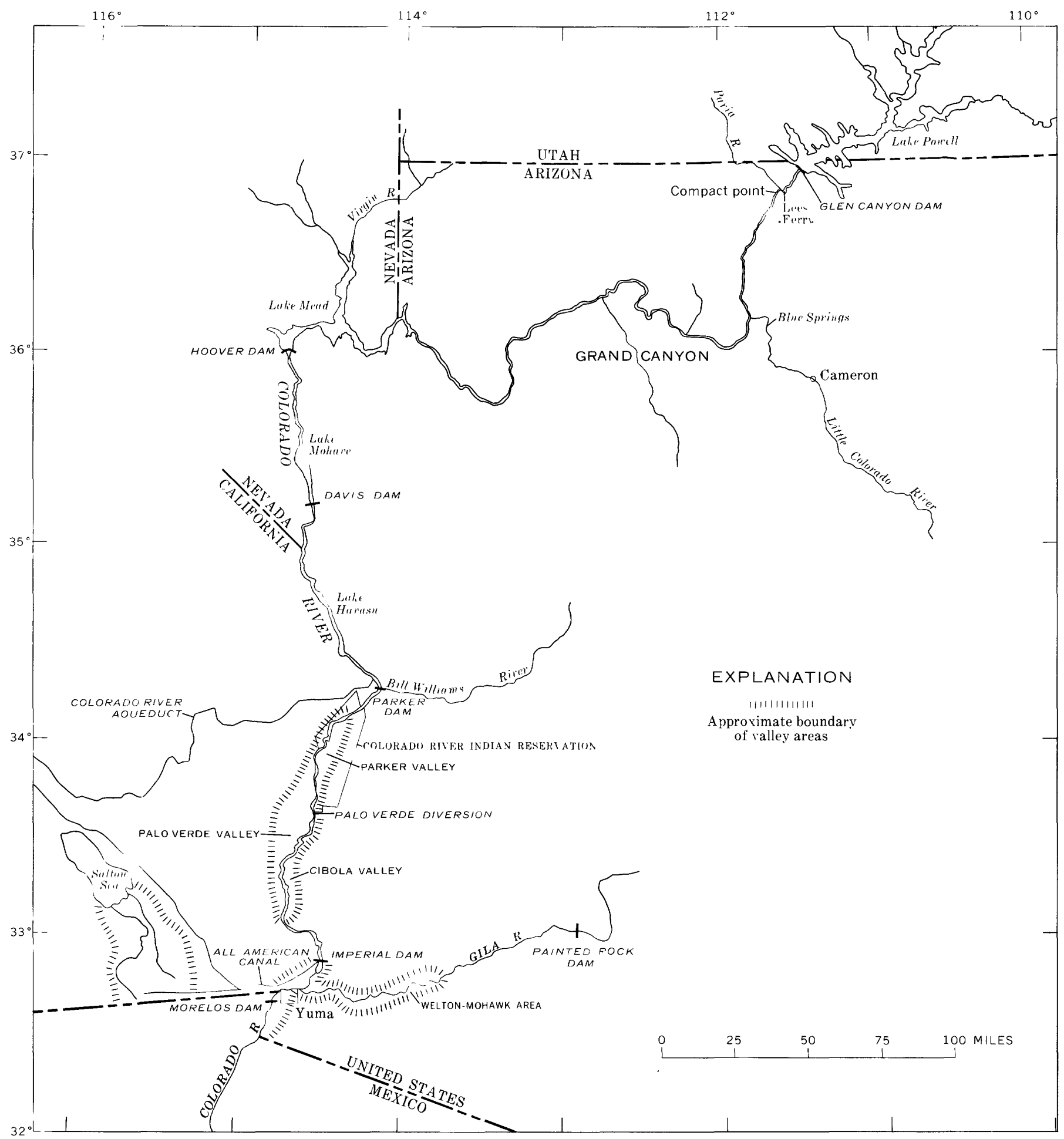

Figure 1.-Principal features of the lower Colorado River-Salton Sea area.

chemical regimen of the river, although not represented by chemical-quality records and therefore unknown, was undoubtedly one of large daily and seasonal variation in both salinity and composition.

Systematic records obtained for various points on the river since 1925 show that the chemical characteristics of the water in the lower river have varied both from point to point and from year to year. Long-term records obtained upstream from Lake Mead, encompassing a period that began after most 
of the Upper Basin irrigation had been developed and before the construction of the Glen Canyon Dam, represent a comparatively stable condition and a regimen that probably differs only slightly from the natural regimen. Data resulting from sampling below Hoover Dam and below Glen Canyon Dam show how the average concentrations have been increased and variations decreased as a result of man's control of the river.

The long-term records show that during larger spring floods above Lake Mead, the river water generally contains 200-350 $\mathrm{mg} / \mathrm{l}$ (milligrams per liter) ${ }^{2}$ of dissolved solids, consisting mainly of calcium bicarbonate. The sulfate concentration always exceeds the chloride concentration. During smaller spring floods the floodwater usually contains 350 $500 \mathrm{mg} / \mathrm{l}$ of dissolved solids with sulfate concentrations about the same as bicarbonate concentrations. During low-flow periods, in fall and winter, the dissolved-solids concentrations have reached $1,500 \mathrm{mg} / \mathrm{l}$ nearly every year and occasionally have reached $1,800 \mathrm{mg} / \mathrm{l}$. During these periods sodium nearly always has been the principal cation, but the mixture of anions has been such that no single salt predominates in the dissolved solids. Short records obtained prior to formation of Lake Mead indicate that the same chemical characteristics then prevailed at Yuma, Ariz.

Because concentrations of dissolved solids generally vary with stream discharge, comparison of water quality at different sites is best made by use of weighted-average concentrations for a particular period, usually a water year in this report. These weighted averages approximate the concentration that would be obtained by analysis of a sample from the streamflow for the entire year if it were well mixed. Weighted-average concentrations are computed from the available chemical analyses and the streamflow records by assigning the volumes of flow occurring during designated time intervals to the chemical analyses of water samples taken during those flow periods and by assigning estimates of analyses for any unsampled periods. The weighted averages are the quantities obtained by adding the products of the concentrations and the corresponding flow volumes and dividing by the total flow for the period averaged.

Weighted-average concentrations have been published previously for some, but not all, of the Colo-

\footnotetext{
2 The original analytical data summarized in this report generally state concentrations in parts per million. Recently, however, the Geological Survey has adopted the policy of reporting concentrations as milligrams per liter and this report follows that system. Except for concentrations above about $7,000 \mathrm{ppm}$, the two systems are numerically equal.
}

rado River sampling records. The reliability of weighted-average analyses representing the individual yearly flows at the specified sampling points depends on the number and distribution of samples analyzed, the accuracy of the individual analytical determinations, and the accuracy of the streamflow record. For the years of published weighted averages there have been numerous sampling schedules, variable completeness of the individual chemical analyses, and many different analytical procedures. Therefore, the published weighted averages have not been equally representative of water quality. Consequently, evaluating the long-term variations in Colorado River salinity and the changes caused by man's activities has necessarily involved reviewing the records of chemical analyses for completeness of sampling and representativeness of reported analytical values. It has also involved estimating values when none were available, recomputation of some previously computed weighted-average concentrations, and estimating weighted averages for unsampled years by using sampling records at other river points as guides. As a result of this reappraisal, the tables of weighted-average concentrations in this report differ in some respect from previously published weighted averages. The tables also include weighted averages of individual constituents not previously published.

Annual weighted-average concentrations for the five long-term sampling points most useful in evaluating water-quality variation in the lower Colorado River are given in tables 1-5. The tables include only years of actual sampling for the years prior to 1941 , but to provide a 25 -year record to use in tracing mineral movement down the river they include estimates for all unsampled years from 1941 on.

Comparison of the ionic and dissolved-solids concentrations at different points for the same year shows generally increasing concentrations downstream and more variation in the annual weighted averages of most constituents above Lake Mead than below it. To understand the variation of salinity in the river it is therefore necessary to consider each sampling record in turn.

\section{LEES FERRY}

The Colorado River at Lees Ferry, which is above the confluence of the Paria River, contributes considerably more than 99 percent of the average surface flow at compact point, the division between the upper and lower Colorado River. Hence, records for Lees Ferry (table 1) provide accurate indices of streamflow and water-quality variation at compact 
TABLE 1.-Annual weighted-average concentration for Colorado River at Lees Ferry, Ariz.

[Results in milligrams per liter unless otherwise indicated. * (estimated) signifies concentrations determined indirectly instead of by weighting individual analyses]

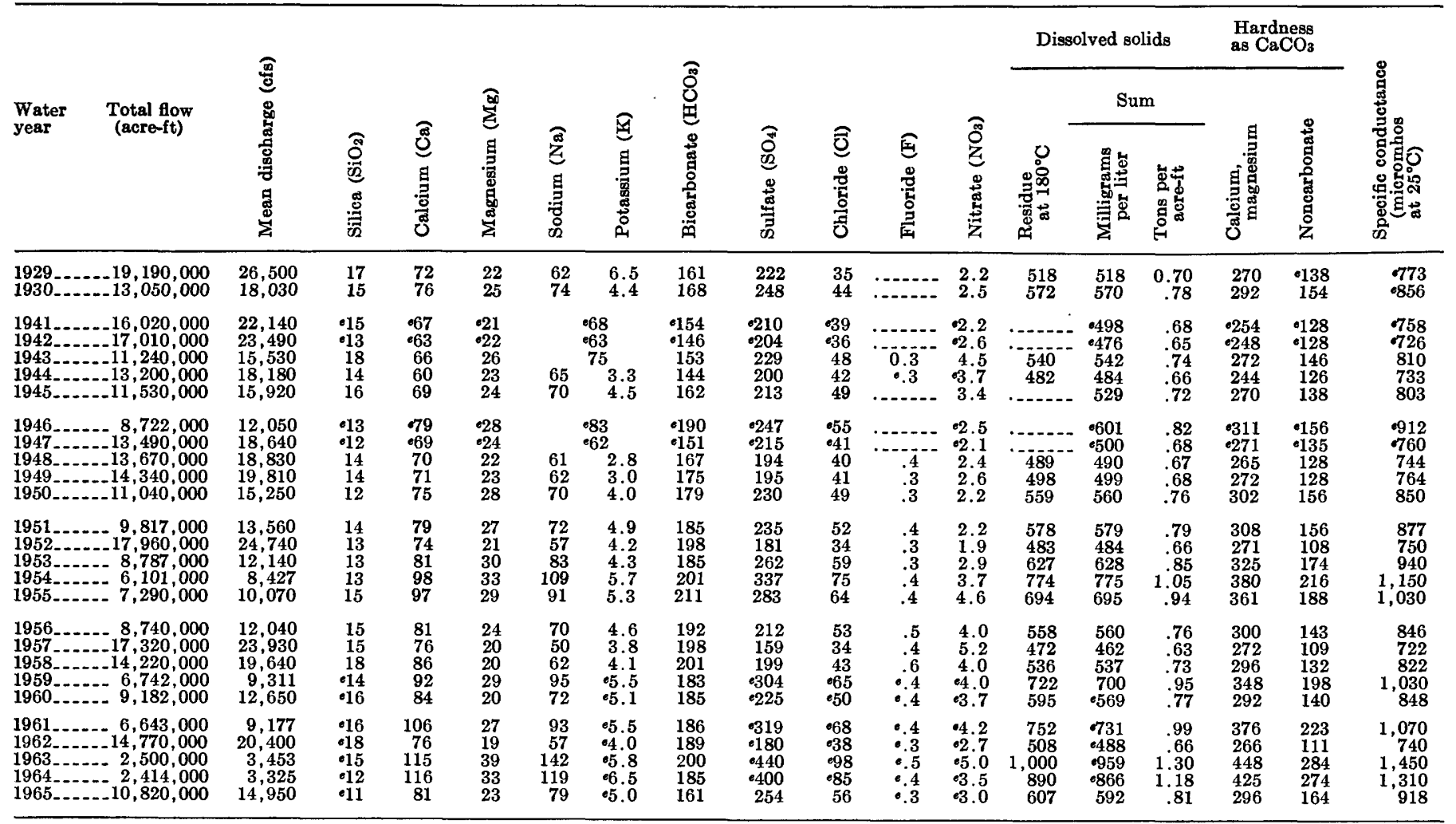

point, about a mile downstream. The concentrations of dissolved solids in table 1 generally tend to decrease with increase in streamflow. Most of the major ionic constituents correlate with streamflow in much the same way as dissolved solids, but the minor constituents do not show the same consistency between concentration and flow.

Prior to construction of Glen Canyon Dam (16 miles upstream) the averages of the daily concentrations of dissolved solids at Lees Ferry were substantially larger than the computed annual weightedaverage concentrations. This is no longer true. Iorns, Hembree, and Oakland (1965) prepared a dissolvedsolids duration table for the period 1914-57 which included the values listed below.

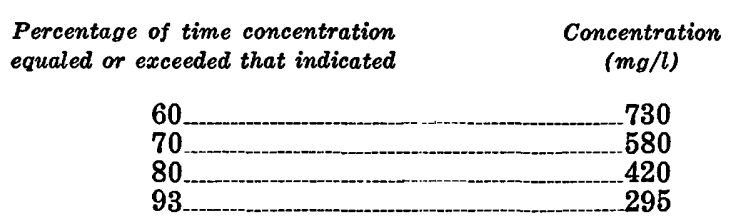

They estimated the weighted average for 1914-57 to be $499 \mathrm{mg} / \mathrm{l}$, corresponding to an average annual discharge of $12,710,000$ acre-feet. They also estimated that the weighted-average concentrations of dissolved solids at Lees Ferry increase about 3.4 $\mathrm{mg} / \mathrm{l}$ for each 100,000 acre-feet diverted out of the basin in headwater areas and about $13.3 \mathrm{mg} / \mathrm{l}$ for each 100,000 acres of newly irrigated land above compact point. An increase of not more than 400,000 acre-feet for out-of-basin diversion and about 50,000 acres of newly irrigated land is a reasonable estimate of the maximum extent of these factors since 1957. Thus, the 1965 weighted average of dissolved solids at Lees Ferry has been increased by no more than $20 \mathrm{mg} / \mathrm{l}$ since Iorn's study period.

Storage of water in Lake Powell began in March 1963, and Colorado River flows immediately downstream were extremely low in 1963 and 1964 because of retention of water in the reservoir. During the 2 years, the weighted-average concentrations of dissolved solids, sulfate, and chloride at Lees Ferry were higher than those for any previous year of record. Then in 1965, when releases, from Lake Powell were increased to near median annual river flows, the concentrations were only slightly above the previous range for similar volumes of flow. The 1965 concentration $(592 \mathrm{mg} / \mathrm{l}$ for an annual flow of $10,820,000$ acre-ft) was only slightly larger than the 5 -year average concentration for $1958-62(575 \mathrm{mg} / \mathrm{l}$ for an average annual flow of 10,311,000 acre-ft). 
The small apparent increase in concentration for 1965 over that for 1958-62 may be partly due to the combined effects of solution from the bed of Lake Powell and evaporation of pure water from its surface, but it is probably mainly due to errors in the sampling and changes in streamflow.

\section{GRAND CANYON}

A program of systematic (mostly daily) water sampling for chemical analysis has been in operation longer and with fewer unsampled periods at Grand Canyon than at any other point on the Colorado River. The Grand Canyon record (table 2) is based on sampling during every year except 1943, for which year the concentration was estimated from records at Lees Ferry. Because of its greater length, more comprehensive character, and closer proximity to the major areas of water use, this record provides a better index of natural variability of lower Colorado River salinity than the shorter and less complete Lees Ferry record, which has been considered as the reference record in some other studies.

Comparisons between the annual concentrations given for Grand Canyon in table 2 with those given for Lees Ferry in table 1 indicate that the water at the lower station regularly has moderately higher concentrations of several constituents.

Although table 2 gives both the annual streamflows and corresponding annual weighted-average analyses for Colorado River water at Grand Canyon, the relation between streamflows and concentrations is not readily apparent. To make the relation clearer, the annual streamflows and annual weighted average of dissolved-solids concentrations are plotted as paired bars in figure 2. No significant change in the relation between annual discharge and average con-

TABLE 2.-Annual weighted-average concentration for Colorado River at Grand Canyon, Ariz.

[Results in milligrams per liter unless otherwise indicated. - (estimated) signifies concentrations determined indirectly instead of by weighting individua] analyses ]

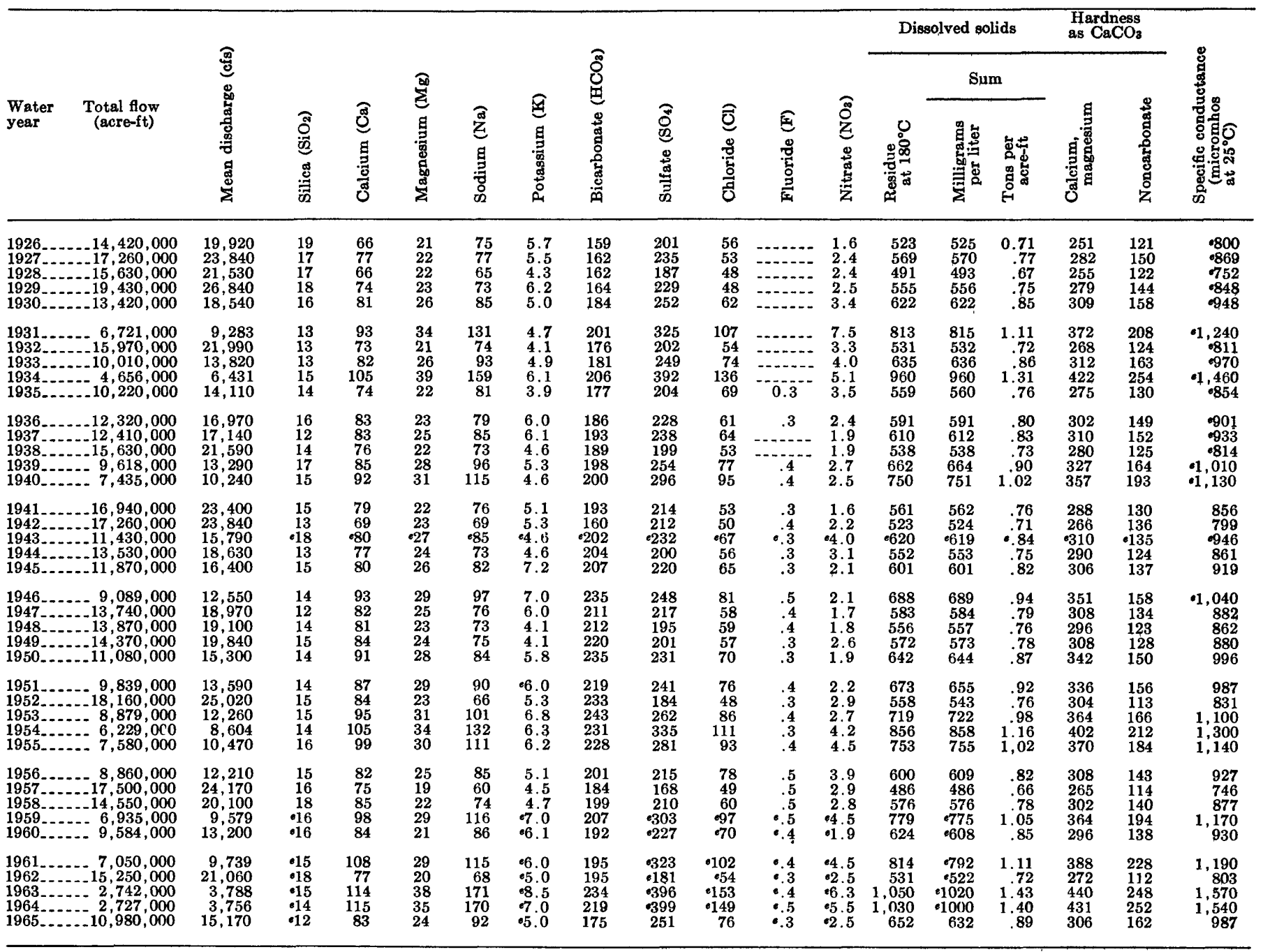




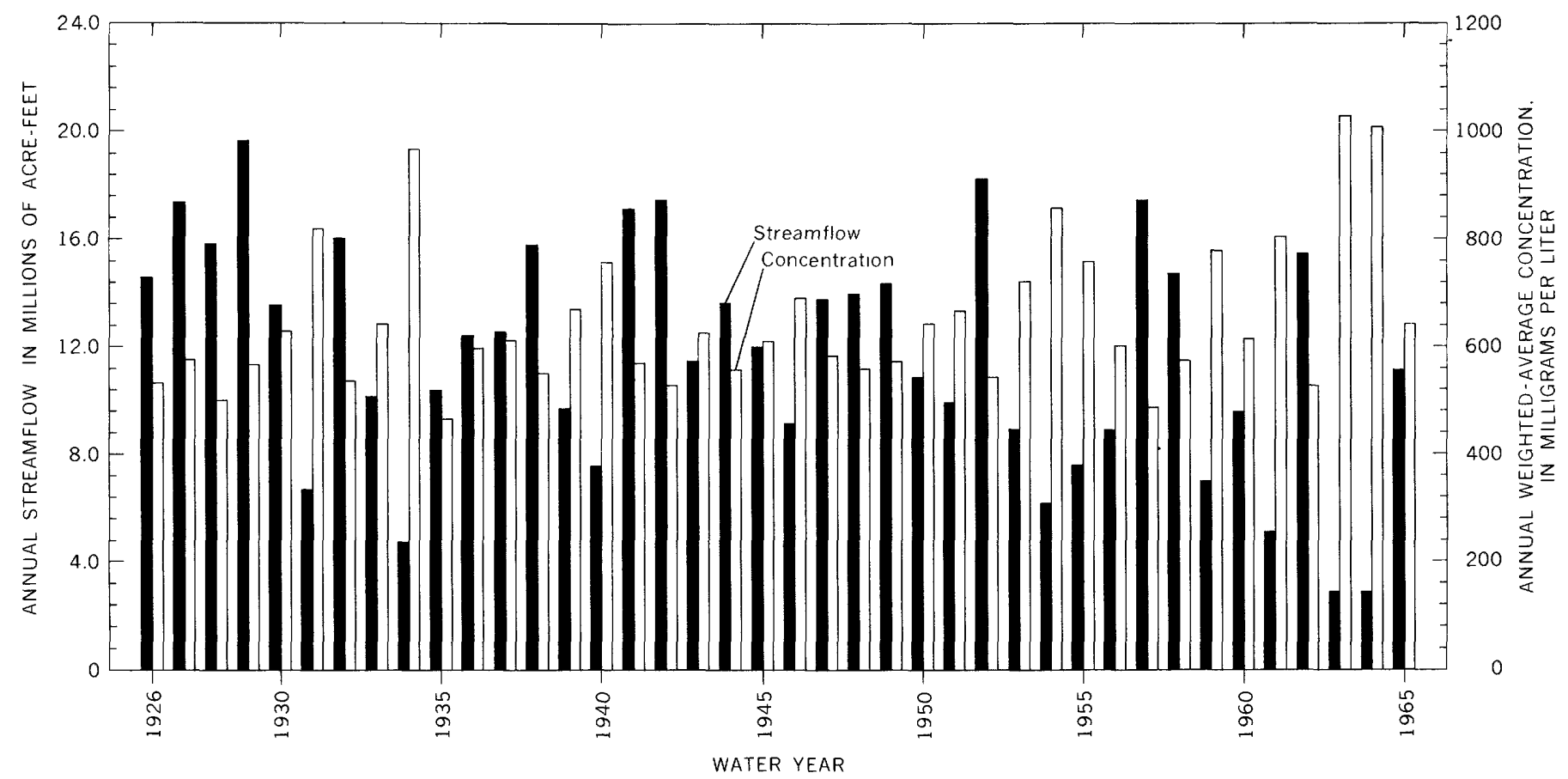

Figure 2.-Annual streamflow and annual weighted-average concentration of dissolved solids, Colorado River at Grand Canyon, $1926-65$.

centration is suggested by the figure, except the temporary one caused by closure of Glen Canyon Dam in 1963. The figure clearly shows that the years with the greatest streamflow have had among the lowest dissolved-solids concentrations and that years of approximately equal streamflow have had only moderate variations in average concentrations. Thus, so far as can be determined from the parallel plotting, the Colorado River had a nearly stable chemical regimen during the years 1926-62. The great change in regimen caused by closure of Glen Canyon Dam in 1963 seems to have been limited to 2 years, as the relation between salinity and streamflow for 1965 is within the range that might have been expected for the volume of flow.

Comparison of the annual analyses in table 2 shows that all the major ions contribute to the variation in dissolved solids at Grand Canyon. Most of the salinity changes, however, result from changes in the concentrations of the anions, so the general nature of the chemical regimen of the river can be determined by considering only the major anions. Thus, the line connecting yearly dissolved-solids concentrations in figure 3 is roughly parallel to lines formed from yearly weighted-average concentrations of sulfate, bicarbonate, and chloride; this indicates fairly consistent inter-ionic relationships. Figure 3 shows that the annual chloride concentration at Grand Canyon has always been much less than the annual bicarbonate and sulfate concentrations, that in most years the sulfate concentration has exceeded the bicarbonate concentration, but that for those years with low dissolved-solids concentrations the sulfate was nearly equal to or less than the bicarbonate.

Most of the annual bicarbonate concentrations at Grand Canyon prior to 1943 were lower and changed less from year to year than the later ones. A possible explanation for this apparent change in regimen is that during the first years of sampling long delays occurred between sample collection and analysis. Consequently, there may have been considerable calcium carbonate precipitation in the more concentrated samples prior to chemical analysis that would have resulted in low values for the yearly bicarbonate concentrations. If during the early years the individually determined bicarbonate concentrations averaged $20-30 \mathrm{mg} / \mathrm{l}$ lower than the true values-a reduction which appears possible from a study of figure 3 and of the original data-the long-time dissolved-solids concentration reported as $598 \mathrm{mg} / \mathrm{l}$ in table 6 may be $10-15 \mathrm{mg} / \mathrm{l}$ less than the true value.

Records of water quality obtained at Grand Canyon after the formation of Lake Powell in 1963 are of too short duration to determine the probable future effect of this lake on downstream river-water quality. Chemical analyses of samples obtained through 1965 , however, suggest that some solution of calcium 


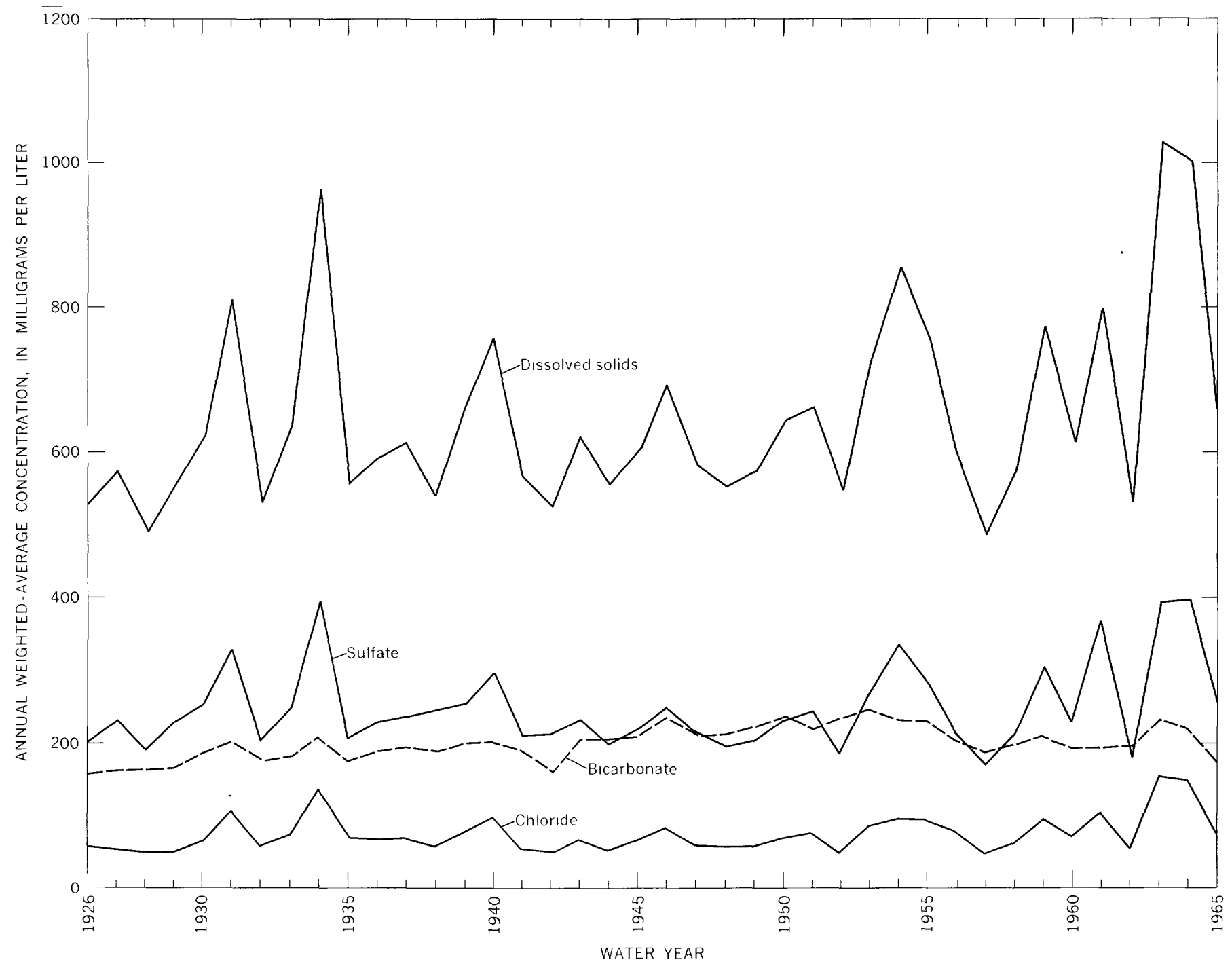

Figure 3.-Annual weighted-average concentration of dissolved solids, sulfate, bicarbonate, and chloride, Colorado River at Grand Canyon, $1926-65$.

sulfate and sodium chloride from the lakebed has occurred and that there may have been some precipitation of calcium carbonate in the lake.

As annual river flows are known to have a small degree of dependence on immediately preceding annual flows with either high or low flow years tending to come together, it is possible that there is a similar sequential dependence of annual weighted-average concentrations. Study of the record for Colorado River at Grand Canyon, however, suggests that any such dependence is small and that annual concentrations are mostly related to annual discharge. Treating the annual concentrations as entirely random is helpful in a statistical summary of their variation (table 3). As most of the flow at Grand Canyon is now regulated by Lake Powell, future fluctuations in annual dissolved-solids concentrations will no doubt be less than those during 1926-62. Nevertheless, ta- ble 3 is of interest because it provides a summary of actual variations during a period of nearly stable irrigation development in the tributary area. The table shows that annual concentrations differ markedly but that averages for periods of 10 or more years usually differ only slightly.

In table 3, concentrations are given in tons per acre foot as well as milligrams per liter because irrigators in the lower Colorado River service area generally are familiar with dissolved-solids concentrations so expressed. Load data, described later, are also given either in tons or tons-equivalent because such expressions have been customary in reports about the Colorado River.

\section{HOOVER DAM}

The record of annual weighted-average concentrations for Colorado River below Hoover Dam (table 
TABLE 3.-Summary of weighted-average concentrations of dissolved solids, Colorado River at Grand Canyon, during selected periods prior to closure of Glen Canyon Dam

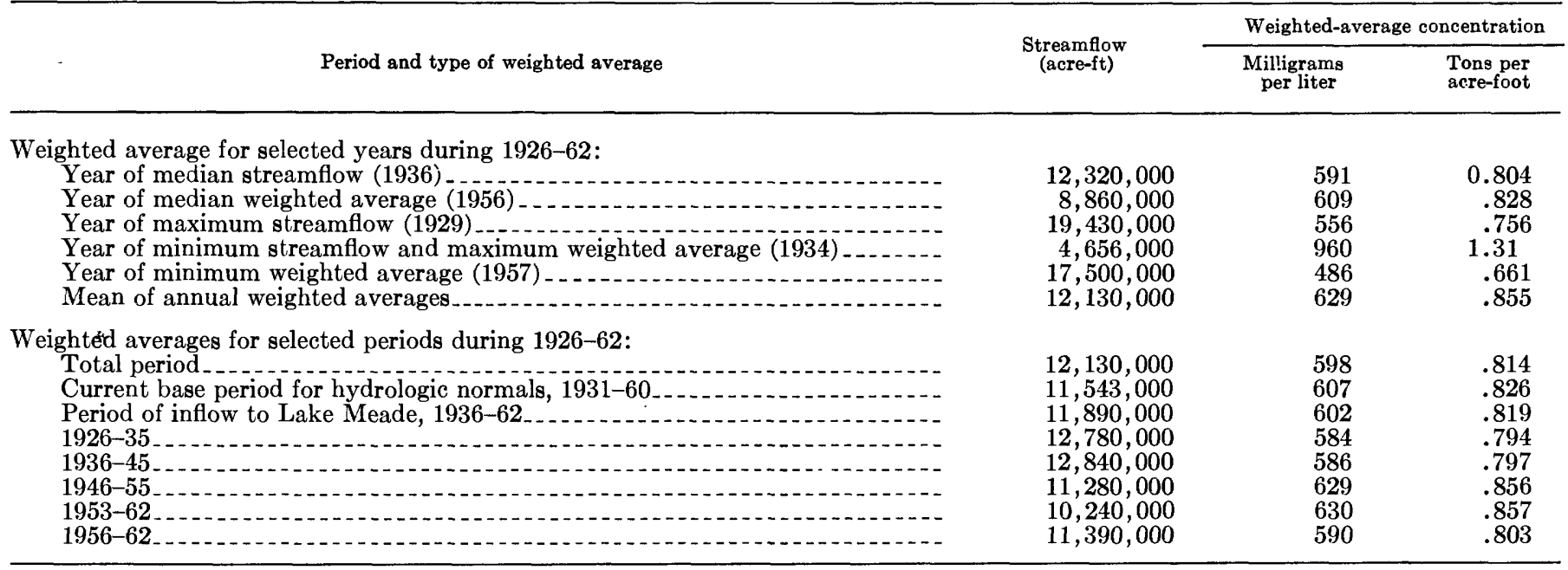

4) includes years when samples were collected at Willow Beach, 10 miles downstream, immediately prior to and during the early part of the filling of Lake Mead. It also includes several years when analyses of samples obtained at various depths between the intake towers of Lake Mead were used as measures of the quality of the water in the river.

Lake Mead is comparable to a huge mixing bowl into which pour the widely variable flows of the Colorado River, the much smaller Virgin River flows, several small spring-fed streams, and the infrequent flows from several generally dry channels. The lake alters the chemical regimen of the river below the lake as well as the streamflow regimen. Thus, it has virtually eliminated the natural daily and seasonal variations of concentration and has much reduced the annual variation. It has brought about changes in the water resulting from precipitation of calcium carbonate and silica and by solution of gypsum and possibly common salt from its bed. Also, evaporation of pure water from the lake has constantly increased the salinity of released water.

Histograms of the annual weighted-average concentration of dissolved solids for 1935-62 (fig. 4) illustrate the increased concentrations and reduced annual variation of Colorado River water below Hoover Dam as compared with that near Grand Canyon.

The records show that the concentrations of Colorado River water below Hoover Dam are still responsive to changes in flow, although the response has been muted by Lake Mead. During wetter periods of a few years, more water has flowed into Lake Mead than could be stored, so more has been released than actually needed by users downstream. During such

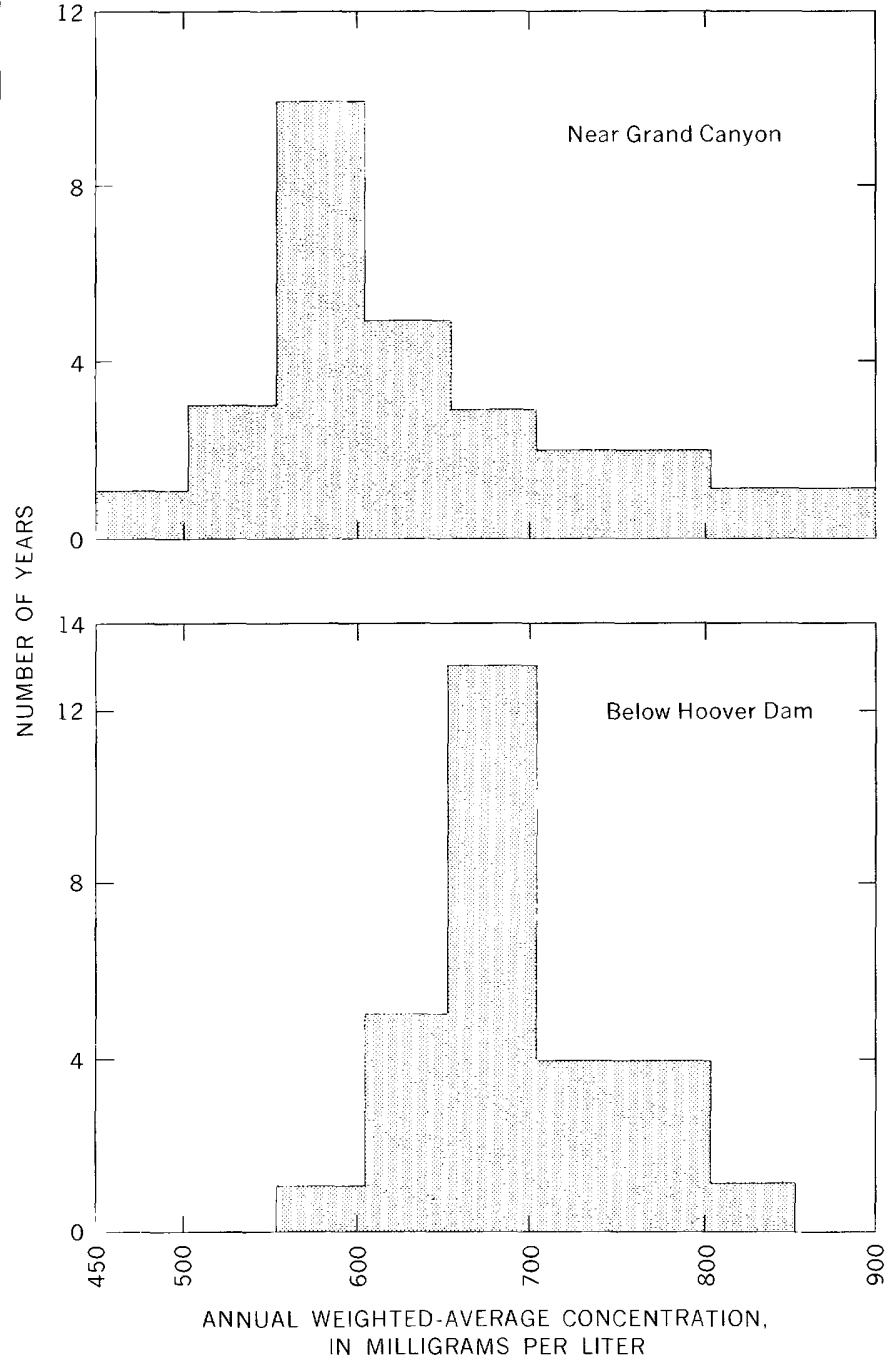

Figure 4.- Histograms of dissolved-solids concentration near Grand Canyon and below Hoover Dam, 1935-62. 
TABLE 4.-Annual weighted-average concentration for Colorado River below Hoover Dam, Ariz.-Nev.

[Results in milligrams per liter unless otherwise indicated. - (estimated) signifies concentrations determined indirectly instead of by weighting individual analyses]

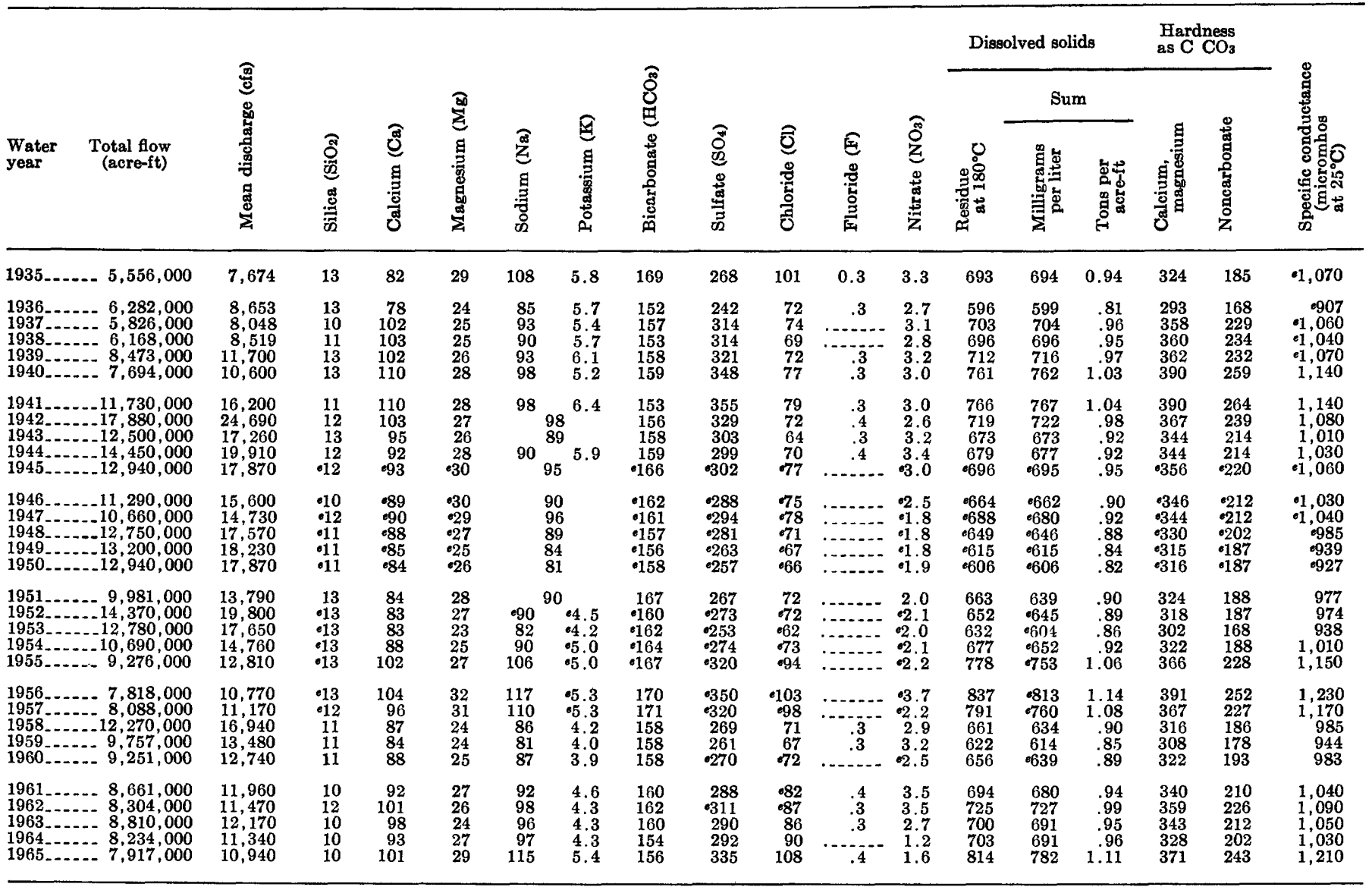

periods the concentrations have generally decreased from year to year. During some dry periods inflow concentrations have been relatively high, and the outflow has been more nearly restricted to downstream water needs; so outflow has exceeded inflow for 2 or 3 consecutive years. The salinity of released water has always risen during such periods.

Because the changes in chemical characteristics of water released from Lake Mead have been of public concern, a brief statement of explanation is in order. Lake Mead began to form in 1935; during the years 1936-41 its contents increased every year except 1940 , the maximum levels vet attained were reached in 1941. In 1936, the chemical character of water released from Lake Mead was similar to the weighted-average flow of the Colorado River at Grand Canvon, but was rarelv like it thereafter. Solution from the newly flooded bottom of Lake Mead was probably greater during the years of the rising lake level than at any time since. As a result of bed solution and the more concentrated inflows of $193^{\circ}$. and 1940, the weighted-average concentrations of dissolved solids and sulfate below Hoover Dam trended upward from 1936 to a maximum in 1940.

During the years 1942-52 the flow at Grand Canvon averaged $13,430,000$ acre-feet, and only 1946 and 1951 had flows of less than 10 million acre-feet. As a result of this long period of comparatively high streamflow, the concentration of dissolved solids, sulfate, and chloride generally declined, reached the lowest on record in 1950, rose slightly in 1951, and again declined to almost the previous lows in 1953 .

The years 1953 to 56 , inclusive, had the four lowest consecutive annual flows ever recorded at Grand Canyon and correspondingly high concentrations. Consequently during this 4-year period the concentrations of dissolved solids, sulfate, and chloride below Hoover Dam rose each year, with the highest annual averages yet experienced occurring in 1956 . Rather high inflow to Lake Mead occurred in 1957-58, and in 1959 the concentrations of the water released from Lake Mead were nearly as low as the minimums of 1953. Three successive years of below- 
average inflow during 1959-61 then resulted in increased concentrations below Hoover Dam each following year. High inflow to Lake Mead in 1963 was followed by reduced salinity below Hoover Dam in both 1963 and 1964.

The regulated low flows at Grand Canyon in 1963 and 1964, each of which was less than two-thirds the unregulated minimum of 1934, were followed in 1965 by markedly higher concentrations below Hoover Dam, with the chloride concentrations reaching an all-time maximum.

This pattern of low inflow at Grand Canyon being followed by rising concentration levels below Hoover Dam, together with the demonstrated effects of Lake Mead on water quality below Hoover Dam, suggest what will happen as Lake Powell rises to higher operating levels. Lake Powell will decrease the variability of concentrations downstream and may cause a slight increase in average concentrations. The resulting more uniform concentrations in the inflow to Lake Mead will further reduce the variability of the concentrations below Hoover Dam, possibly by half.

\section{LAKE HAVASU}

Lakes Mohave and Havasu have only minor effects on the quality of Colorado River water because of their relatively small storage capacity is equal to only a few months of river flow. The inflow between Hoover and Parker Dams is generally so small that its effect on the quality of river water is also negligible.

The first major diversion of water from the lower Colorado River is the water pumped into the Colorado River aqueduct of the Metropolitan Water District of Southern California from Lake Havasu. Hill (1965) published a table of the 20-year (1941-60) ionic burden, in tons, of the Colorado River at Lake Havasu based on analytical records of the Metropolitan Water District. For this report Hill's data were recomputed to give weighted averages representative of inflow to Lake Havasu (table 5), and the period of record was extended through 1965 by using analyses of the Geological Survey and the U.S. Public Health Service. The yearly weighted-average concentrations for Lake Havasu computed from Hill's table agree very well with those for the same years at Hoover Dam, except that Lake Havasu water generally has somewhat less calcium and bicarbonate than the Hoover Dam releases. This difference suggests continued precipitation of calcium carbonate in Lakes Mohave and Havasu.

TABLE 5.-Annual weighted-average concentration for Colorado River at Lake Havasu, Ariz.-Calif. [Results in milligrams per liter unless otherwise indicated. All silica concentrations are estimated]

\begin{tabular}{|c|c|c|c|c|c|c|c|c|c|c|c|c|c|c|}
\hline \multirow{3}{*}{ Water year } & \multirow{3}{*}{$\begin{array}{l}\text { Total flow } \\
\text { (acre-ft) }\end{array}$} & \multirow[b]{3}{*}{ 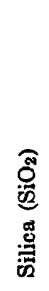 } & \multirow[b]{3}{*}{ 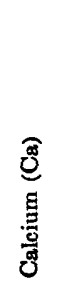 } & \multirow{3}{*}{ 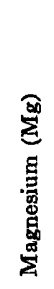 } & \multirow[b]{3}{*}{ 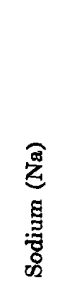 } & \multirow{3}{*}{\multicolumn{2}{|c|}{ 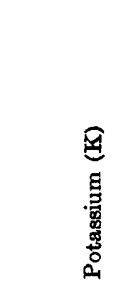 }} & \multirow{3}{*}{ 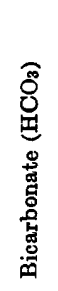 } & \multirow[b]{3}{*}{ 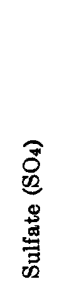 } & \multirow[b]{3}{*}{ 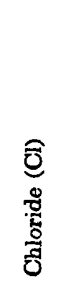 } & \multirow{2}{*}{\multicolumn{2}{|c|}{$\frac{\text { Dissolved solids }}{\text { Sum }}$}} & \multicolumn{2}{|c|}{$\begin{array}{l}\text { Hardness } \\
\text { as } \mathrm{CaCO}_{3}\end{array}$} \\
\hline & & & & & & & & & & & & & \multirow{2}{*}{ 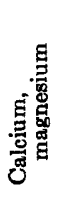 } & \multirow{2}{*}{ 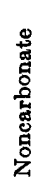 } \\
\hline & & & & & & & & & & & 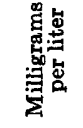 & 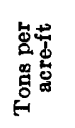 & & \\
\hline $\begin{array}{l}1941 \\
1942 \\
1944 \\
1945\end{array}$ & $\begin{array}{l}11,825,000 \\
17,468,000 \\
11,691,000 \\
13,898,000 \\
12,447,000\end{array}$ & $\begin{array}{l}11 \\
12 \\
13 \\
11 \\
11\end{array}$ & $\begin{array}{r}108 \\
102 \\
94 \\
90 \\
86\end{array}$ & $\begin{array}{l}29 \\
28 \\
28 \\
27 \\
28\end{array}$ & & $\begin{array}{r}101 \\
98 \\
95 \\
94 \\
95\end{array}$ & & $\begin{array}{l}159 \\
159 \\
158 \\
158 \\
158\end{array}$ & $\begin{array}{l}352 \\
329 \\
305 \\
294 \\
\mathbf{2 8 8}\end{array}$ & $\begin{array}{l}79 \\
78 \\
75 \\
75 \\
76\end{array}$ & $\begin{array}{l}758 \\
726 \\
688 \\
669 \\
662\end{array}$ & $\begin{array}{r}1.03 \\
.99 \\
.94 \\
.91 \\
.90\end{array}$ & $\begin{array}{l}388 \\
370 \\
350 \\
336 \\
330\end{array}$ & $\begin{array}{l}258 \\
239 \\
220 \\
206 \\
200\end{array}$ \\
\hline $\begin{array}{l}1946 \\
1947 \\
1948 \\
1950\end{array}$ & $\begin{array}{l}10,962,000 \\
10 ; 416,000 \\
12,581,000 \\
12,917,000 \\
12,224,000\end{array}$ & $\begin{array}{l}11 \\
12 \\
12 \\
12 \\
12\end{array}$ & $\begin{array}{l}86 \\
86 \\
85 \\
82 \\
77\end{array}$ & $\begin{array}{l}28 \\
28 \\
27 \\
25 \\
25\end{array}$ & & $\begin{array}{l}97 \\
96 \\
93 \\
88 \\
85\end{array}$ & & $\begin{array}{l}159 \\
158 \\
155 \\
152 \\
151\end{array}$ & $\begin{array}{l}288 \\
287 \\
279 \\
264 \\
252\end{array}$ & $\begin{array}{l}78 \\
78 \\
76 \\
72 \\
66\end{array}$ & $\begin{array}{l}666 \\
664 \\
648 \\
618 \\
591\end{array}$ & $\begin{array}{l}.91 \\
.90 \\
.88 \\
.84 \\
.80\end{array}$ & $\begin{array}{l}330 \\
330 \\
323 \\
308 \\
295\end{array}$ & $\begin{array}{l}199 \\
200 \\
196 \\
183 \\
171\end{array}$ \\
\hline $\begin{array}{l}1951 \\
1952 \\
1953 \\
1954\end{array}$ & $\begin{array}{r}8,656,000 \\
13,872,000 \\
12,786,000 \\
9,815,000 \\
9,333,000\end{array}$ & $\begin{array}{l}13 \\
13 \\
13 \\
14 \\
14\end{array}$ & $\begin{array}{l}81 \\
79 \\
75 \\
82 \\
88\end{array}$ & $\begin{array}{l}26 \\
26 \\
24 \\
29 \\
31\end{array}$ & & $\begin{array}{r}93 \\
92 \\
83 \\
93 \\
108\end{array}$ & & $\begin{array}{l}153 \\
150 \\
145 \\
153 \\
152\end{array}$ & $\begin{array}{l}270 \\
270 \\
247 \\
278 \\
316\end{array}$ & $\begin{array}{l}75 \\
73 \\
64 \\
76 \\
92\end{array}$ & $\begin{array}{l}633 \\
627 \\
577 \\
648 \\
724\end{array}$ & $\begin{array}{l}.86 \\
.85 \\
.78 \\
.88 \\
.98\end{array}$ & $\begin{array}{l}309 \\
304 \\
286 \\
324 \\
\mathbf{3 4 7}\end{array}$ & $\begin{array}{l}184 \\
181 \\
167 \\
198 \\
222\end{array}$ \\
\hline $\begin{array}{l}1956 \\
1957 \\
1958 \\
1950\end{array}$ & $\begin{array}{r}7,375,000 \\
7,412,000 \\
11,738,000 \\
9,458,000 \\
8,808,000\end{array}$ & $\begin{array}{l}14 \\
12 \\
13 \\
13 \\
13\end{array}$ & $\begin{array}{l}96 \\
96 \\
88 \\
80 \\
80\end{array}$ & $\begin{array}{l}34 \\
33 \\
28 \\
26 \\
26\end{array}$ & & $\begin{array}{r}121 \\
117 \\
93 \\
83 \\
89\end{array}$ & & $\begin{array}{l}152 \\
152 \\
150 \\
140 \\
140\end{array}$ & $\begin{array}{l}352 \\
343 \\
286 \\
265 \\
269\end{array}$ & $\begin{array}{r}106 \\
103 \\
82 \\
69 \\
75\end{array}$ & $\begin{array}{l}798 \\
779 \\
664 \\
605 \\
621\end{array}$ & $\begin{array}{r}1.09 \\
1.06 \\
.90 \\
.82 \\
.84\end{array}$ & $\begin{array}{l}379 \\
375 \\
334 \\
306 \\
306\end{array}$ & $\begin{array}{l}254 \\
250 \\
212 \\
192 \\
192\end{array}$ \\
\hline 1961 & $\begin{array}{l}8,320,000 \\
7,939,000 \\
8,450,000 \\
7,903,000 \\
7,625,000\end{array}$ & $\begin{array}{l}12 \\
12 \\
11 \\
12 \\
11\end{array}$ & $\begin{array}{r}96 \\
104 \\
99 \\
89 \\
104\end{array}$ & $\begin{array}{l}27 \\
27 \\
25 \\
27 \\
30\end{array}$ & $\begin{array}{r}96 \\
102 \\
100 \\
98 \\
120\end{array}$ & & $\begin{array}{l}4.6 \\
4.3 \\
4.3 \\
4.3 \\
5.9\end{array}$ & $\begin{array}{l}157 \\
159 \\
157 \\
150 \\
155\end{array}$ & $\begin{array}{l}299 \\
325 \\
302 \\
290 \\
348\end{array}$ & $\begin{array}{r}85 \\
91 \\
90 \\
90 \\
113\end{array}$ & $\begin{array}{l}702 \\
748 \\
712 \\
685 \\
811\end{array}$ & $\begin{array}{r}.95 \\
1.02 \\
.97 \\
.93 \\
1.10\end{array}$ & $\begin{array}{l}350 \\
373 \\
349 \\
334 \\
383\end{array}$ & $\begin{array}{l}222 \\
244 \\
220 \\
210 \\
256\end{array}$ \\
\hline
\end{tabular}


The table of weighted averages for Colorado River at Lake Havasu also represents very nearly the concentrations of water diverted for irrigation in the Colorado River Indian Reservation (Parker Valley, Ariz.) and in the Palo Verde Valley, Calif.

\section{IMPERIAL DAM}

At Imperial Dam the Colorado River water is divided into three parts: the major part is diverted to the All-American Canal, a lesser amount to the Gila Gravity Main Canal, and the remainder is released down the river channel. Samples are collected at regular intervals from the Yuma Main Canal, which receives water from the All-American Canal. The analyses of these samples, published in annual water-supply papers of the U. S. Geological Survey "Quality of Surface Waters of the United States" as Yuma Main Canal, thus represent the quality of the water at Imperial Dam. This water is used for irrigation and municipal supply in most areas below the dam and in much of the Salton Sea basin. The record in table 6 for Colorado River at Imperial Dam also includes some years during which the sampling was directly from the Colorado River at Yuma and some estimated averages.
Comparison of the data in table 5 with those in table 6 shows that concentrations of dissolved solids and most of the major ionic constituents at Imperial Dam are greater than those at Lake Havasu and that the differences have been increasing. The increases are caused mainly by irrigation drainage returned to the river in the Colorado River Indian Reservation (Parker Valley) and the Palo Verde Valley, where there have been rather large increases of irrigated acreage in the past 25 years. Diversion through the Colorado River aqueduct to southern California, however, has increased during the same period from nearly insignificant amounts to about one-seventh of the water released at Hoover Dam. This increase has resulted in less water being available to dilute the saline irrigation return flows from Parker and Palo Verde Valleys and thereby has raised the salinity of water at Imperial Dam.

\section{MINERAL BURDEN OF THE LOWER COLORADO RIVER, 1926-65}

The mineral burden, or dissolved load, of the Colorado River at any point is the total quantity (weight) of dissolved minerals in the water flowing

TABLE 6.-Annual weighted-average concentration for Colorado River at Imperial Dam, Ariz.-Calif.

[Results in milligrams per liter unless otherwise indicated. - (estimated) signifies concentrations determined indirectly instead of by weighting individual analyses]

\begin{tabular}{|c|c|c|c|c|c|c|c|c|c|c|c|c|c|c|c|c|c|c|}
\hline \multirow[b]{3}{*}{$\begin{array}{c}\text { Water } \\
\text { year }\end{array}$} & \multirow[b]{3}{*}{$\begin{array}{l}\text { Total flow } \\
\text { (acre-ft) }\end{array}$} & \multirow{3}{*}{ 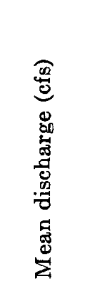 } & \multirow[b]{3}{*}{ 突 } & \multirow[b]{3}{*}{ 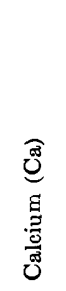 } & \multirow{3}{*}{ 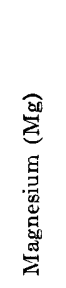 } & \multirow[b]{3}{*}{ 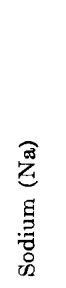 } & \multirow[b]{3}{*}{ 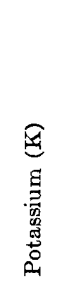 } & \multirow{3}{*}{ 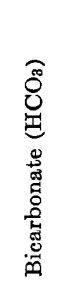 } & \multirow[b]{3}{*}{ 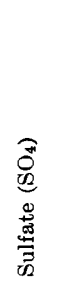 } & \multirow[b]{3}{*}{ 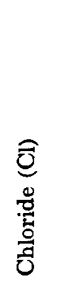 } & \multirow[b]{3}{*}{ 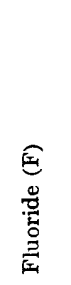 } & \multirow[b]{3}{*}{ 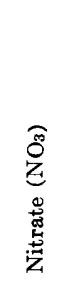 } & \multirow{2}{*}{\multicolumn{3}{|c|}{$\frac{\text { Dissolved solids }}{\text { Sum }}$}} & \multicolumn{2}{|c|}{$\underset{\text { as } \mathrm{CaCO}_{3}}{\text { Hardness }}$} & \multirow{3}{*}{ 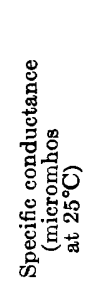 } \\
\hline & & & & & & & & & & & & & & & & \multirow[b]{2}{*}{ 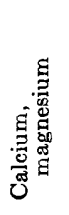 } & \multirow[b]{2}{*}{ 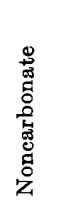 } & \\
\hline & & & & & & & & & & & & & 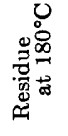 & 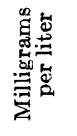 & 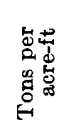 & & & \\
\hline $\begin{array}{l}1946- \\
1947- \\
1948- \\
1949- \\
1950-.\end{array}$ & $\begin{array}{r}10,160,000 \\
-19 ; 714,000 \\
-11,730,000 \\
-12,270,000 \\
-11,500,000\end{array}$ & $\begin{array}{l}14,040 \\
13,420 \\
16,160 \\
16,940 \\
15,890\end{array}$ & $\begin{array}{l}13 \\
12 \\
13 \\
13 \\
13\end{array}$ & $\begin{array}{l}87 \\
92 \\
89 \\
88 \\
84\end{array}$ & $\begin{array}{l}30 \\
31 \\
28 \\
28 \\
27\end{array}$ & $\begin{array}{r}98 \\
104 \\
100 \\
89 \\
88\end{array}$ & $\begin{array}{l}5.9 \\
4.1 \\
3.3 \\
6.4 \\
2.9\end{array}$ & $\begin{array}{l}160 \\
165 \\
165 \\
165 \\
163\end{array}$ & $\begin{array}{l}295 \\
310 \\
292 \\
281 \\
265\end{array}$ & $\begin{array}{l}83 \\
89 \\
82 \\
74 \\
75\end{array}$ & $\begin{array}{l}.2 \\
.2 \\
.2 \\
.3 \\
.3\end{array}$ & $\begin{array}{l}1.0 \\
1.3 \\
1.5 \\
1.8 \\
1.4\end{array}$ & $\begin{array}{l}692 \\
726 \\
690 \\
663 \\
637\end{array}$ & $\begin{array}{l}692 \\
725 \\
690 \\
663 \\
637\end{array}$ & $\begin{array}{l}.94 \\
.99 \\
.94 \\
.90 \\
.87\end{array}$ & $\begin{array}{l}340 \\
357 \\
337 \\
334 \\
320\end{array}$ & $\begin{array}{l}210 \\
222 \\
202 \\
200 \\
187\end{array}$ & $\begin{array}{r}1,050 \\
1,100 \\
1,060 \\
1,010 \\
985\end{array}$ \\
\hline $\begin{array}{l}1956 .- \\
1957- \\
1958- \\
1959-- \\
1960 . .\end{array}$ & $\begin{array}{r}6,323,000 \\
-6,279,000 \\
-10,707,000 \\
-8,246,000 \\
-7,338,000\end{array}$ & $\begin{array}{r}8,710 \\
8,673 \\
14,790 \\
11,390 \\
10,110\end{array}$ & $\begin{array}{r}15 \\
13 \\
20 \\
\text { e17 } \\
\mathbf{1 1 8}\end{array}$ & $\begin{array}{r}106 \\
110 \\
93 \\
91 \\
93\end{array}$ & $\begin{array}{l}34 \\
34 \\
27 \\
25 \\
26\end{array}$ & $\begin{array}{l}137 \\
130 \\
117 \\
107 \\
112\end{array}$ & $\begin{array}{l}5.6 \\
5.4 \\
4.9 \\
e .9 \\
e 4.5\end{array}$ & $\begin{array}{l}173 \\
175 \\
171 \\
164 \\
163\end{array}$ & $\begin{array}{r}375 \\
364 \\
304 \\
e 288 \\
e 299\end{array}$ & $\begin{array}{r}126 \\
126 \\
97 \\
e 96 \\
e 104\end{array}$ & $\begin{array}{l}.4 \\
.44 \\
.6 \\
.44 \\
. .4\end{array}$ & $\begin{array}{r}1.7 \\
1.1 \\
1.9 \\
e 1.7 \\
e 1.6\end{array}$ & $\begin{array}{l}917 \\
884 \\
763 \\
746 \\
764\end{array}$ & $\begin{array}{l}886 \\
870 \\
750 \\
710 \\
739\end{array}$ & $\begin{array}{l}1.20 \\
1.18 \\
1.02 \\
.97 \\
1.01\end{array}$ & $\begin{array}{l}404 \\
414 \\
343 \\
330 \\
339\end{array}$ & $\begin{array}{l}262 \\
270 \\
203 \\
196 \\
205\end{array}$ & $\begin{array}{l}1,340 \\
1,340 \\
1,140 \\
1,080 \\
1,130\end{array}$ \\
\hline $\begin{array}{l}1961 \ldots \\
1962 .- \\
1963- \\
1964- \\
1965 \ldots\end{array}$ & $\begin{array}{r}6,527,000 \\
-\quad 6,220,000 \\
-6,612,000 \\
-6,076,000 \\
-5,766,000\end{array}$ & $\begin{array}{l}9,016 \\
8,591 \\
9,133 \\
8,370 \\
7,964\end{array}$ & $\begin{array}{l}\cdot 16 \\
16 \\
15 \\
16 \\
16\end{array}$ & $\begin{array}{r}98 \\
99 \\
100 \\
95 \\
104\end{array}$ & $\begin{array}{l}27 \\
29 \\
27 \\
28 \\
31\end{array}$ & $\begin{array}{l}126 \\
133 \\
129 \\
131 \\
150\end{array}$ & $\begin{array}{l}.4 .9 \\
e 5.5 \\
e 5.2 \\
e 5.1 \\
e 5.7\end{array}$ & $\begin{array}{l}167 \\
164 \\
167 \\
165 \\
168\end{array}$ & 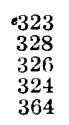 & $\begin{array}{l}e 117 \\
126 \\
118 \\
122 \\
142\end{array}$ & $\begin{array}{l}e .4 \\
.6 \\
.6 \\
e .5 \\
.4\end{array}$ & $\begin{array}{l}.2 .0 \\
1.8 \\
1.2 \\
1.4 \\
1.1\end{array}$ & $\begin{array}{l}821 \\
814 \\
799 \\
835 \\
912\end{array}$ & $\begin{array}{l}797 \\
820 \\
804 \\
806 \\
894\end{array}$ & $\begin{array}{l}1.08 \\
1.12 \\
1,09 \\
1.10 \\
1.22\end{array}$ & $\begin{array}{l}356 \\
366 \\
360 \\
352 \\
387\end{array}$ & $\begin{array}{l}218 \\
232 \\
224 \\
216 \\
249\end{array}$ & $\begin{array}{l}1,220 \\
1,260 \\
1,240 \\
1,240 \\
1,380\end{array}$ \\
\hline
\end{tabular}


in the river past that point in a definite time interval. Loads of specific periods are computed from the weighted-average concentrations found by chemical analyses and the volumes of streamflow in the same periods and are usually stated in tons per day or tons per year. In the unregulated part of the river, high concentrations and smaller loads generally occur during periods of low streamflow and low concentrations and larger loads occur during periods of high streamflow. Thus, prior to construction of Glen Canyon Dam, the seasonal loads above Lees Ferry changed less than the flows or concentrations. Below Hoover Dam, where streamflow is almost completely regulated, concentrations now change rather slowly and almost independently of river volume, whereas loads change very nearly in proportion to streamflow.

Although load computations have no immediate importance to water users, they are important in salinity appraisals because they show downstream movement of dissolved minerals and indicate chemical changes in the river and in the storage reservoirs.

Load analysis is a technique of investigating the chemical regimen of a river by comparing mineral loads carried at different points or during different times. In the remainder of this report, load analysis of the Colorado River is the principal investigative technique. Load analysis is used to investigate the chemical regimen first by considering the loads of all the dissolved solids and then by considering the dissolved-solids load as made up of individual ionic loads undergoing chemically related changes.

\section{ANALYSIS OF DISSOLVED-SOLIDS LOADS}

Plotting annual dissolved-solids loads near Grand Canyon against annual river discharges for the period 1926-62 (fig. 5) results in a scatter diagram unlike that produced by plotting the annual concentrations against annual discharges (fig. 5). The relation between the annual loads and the annual discharges can be represented approximately by a straight line for the range defined by data. As the load for a year of no flow would be zero, however, the relation logically includes a curving segment for very low annual flows. In contrast to the load-flow curve, which rises with increasing annual flow, the concentration-flow curve declines with increasing annual flows. The latter curve changes in slope at a decreasing rate as flow increases, and this change indicates that at very high discharges the mineral concentrations are mostly related to the solubility of products of rock weathering and are less controlled by the fairly constant quantities of soluble salts entering the river in ground-water flow.
The scatter of the points in figure 5 shows that the relation between the annual dissolved-solids loads at Grand Canyon and the annual discharges is somewhat variable. A question arises as to whether there have been any real changes in the chemical regimen during the period of record. Although the question cannot be positively answered, several different methods of plotting dissolved-solids loads against time or stream discharges give indications of a small change in, regimen with the dissolvedsolids load in proportion to discharge somewhat greater after the middle 1950's.

A mass diagram of cumulative dissolved-solids loads for Colorado River at Grand Canyon for 1926-62 shows six time-trends indicated by letter arrows in figure 6 ; the trends are predominantly related to wet or dry periods lasting for several years but may also be influenced by upstream developments. The trends shown for the 1960's resulted from the filling of Lake Powell and other upstream reservoirs. Although the diagram indicates trends lasting a few years have characterized the chemical

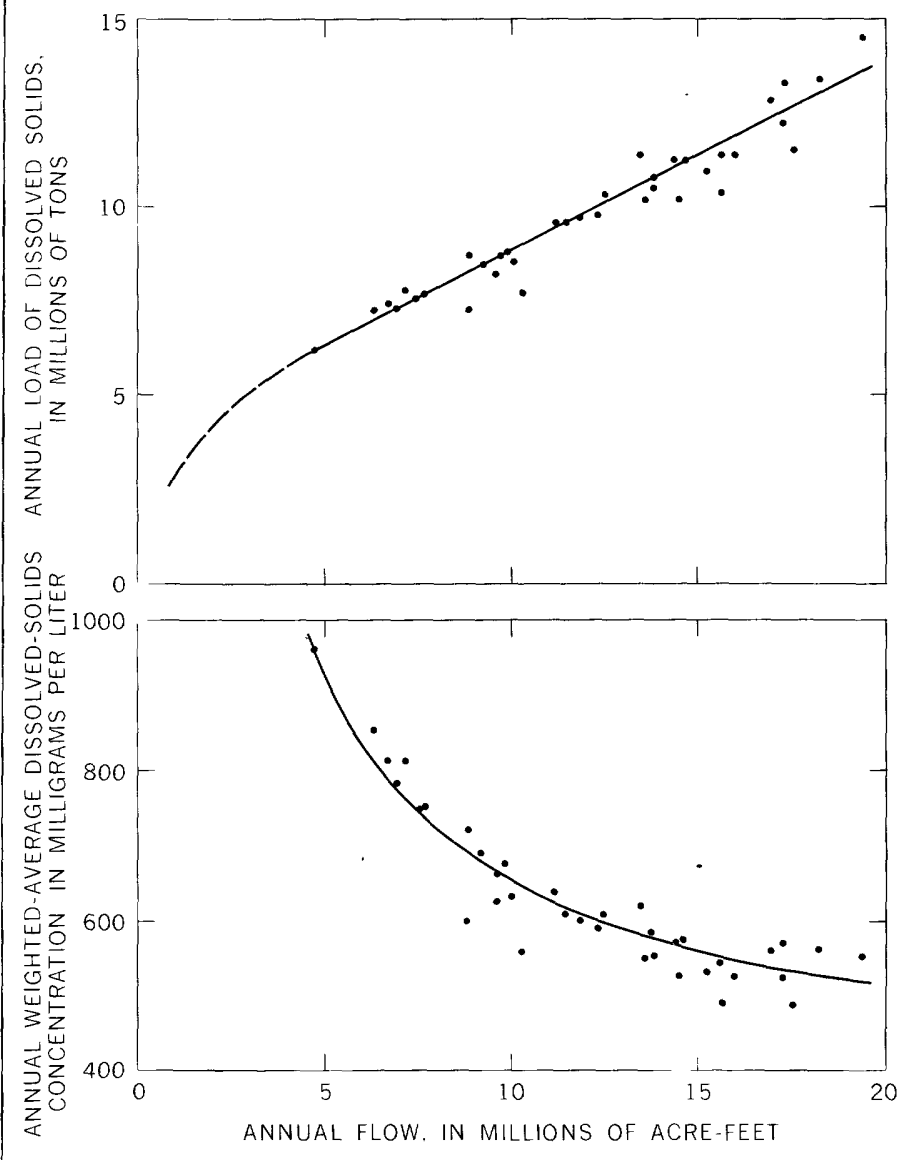

Figure 5.-Approximate relations of dissolved-solids load and concentration to flow of Colorado River near Grand Canyon, Ariz., 1926-62. 


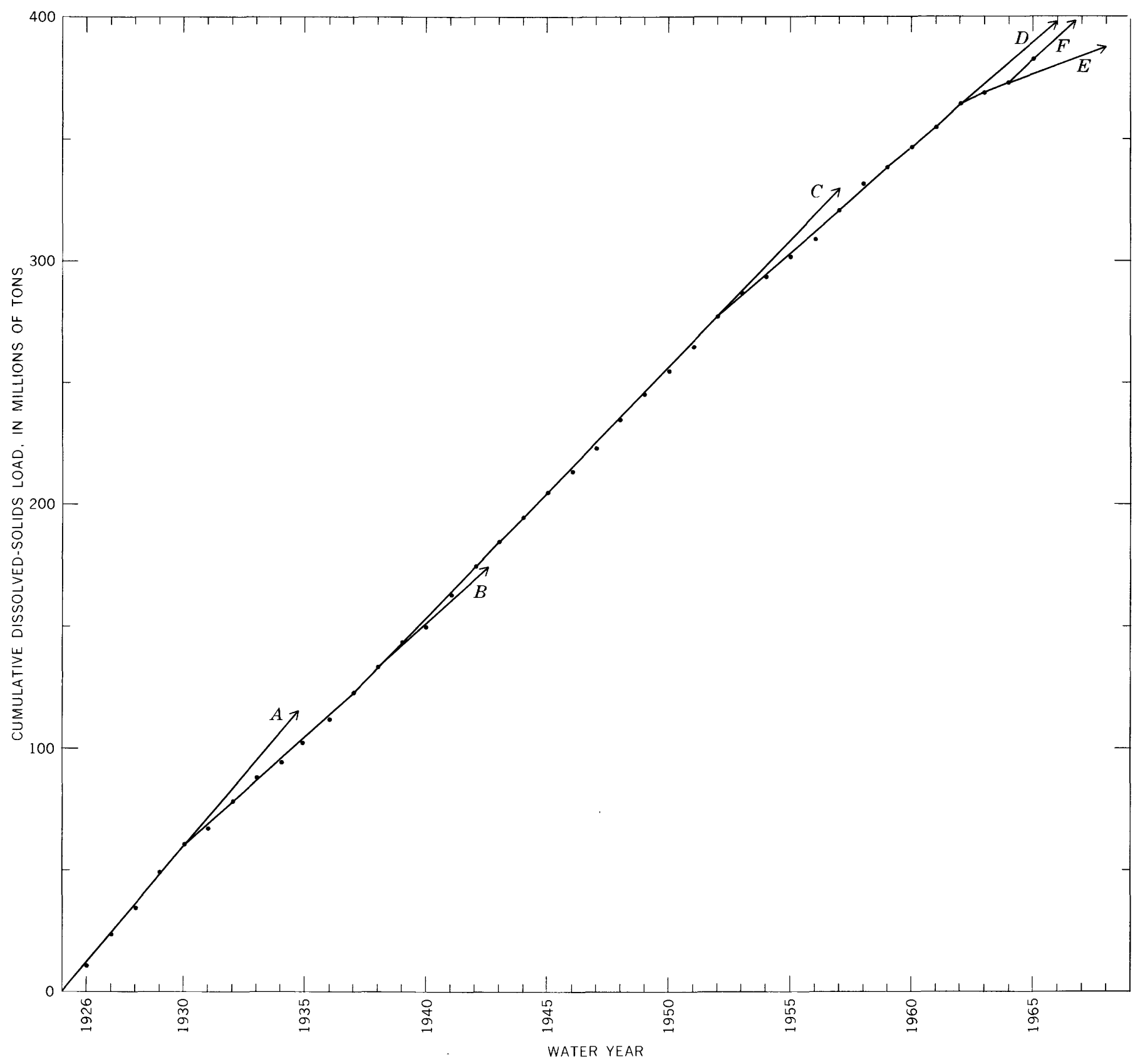

Figure 6.-Mass diagram of cumulative dissolved-solids load, Colorado River at Grand Canyon, $1926-65$.

regimen of the Colorado River, the amount of changes indicated are quite small and do not suggest any major change during the period of record.

A double-mass diagram, produced by plotting cumulative dissolved-solids loads against cumulative annual river discharges at Grand Canyon (fig. 7), shows a nearly linear slope of about 0.8 prior to 1952, indicating a very stable load-flow regimen. After 1952, the plotted points increasingly diverge from the line with 0.8 slope. Such a change in slope suggests a change in the relation between the two variables cumulatively plotted. The departures after 1952 from the previous line of relation, however, are small and in the same direction and are attributed to the expansion of storage of the headwater areas of the river in Colorado and transmountain diversion of water from them. These regimen changes began about 1950 and increased irregularly thereafter.

To ascertain whether the changing relation indi- 


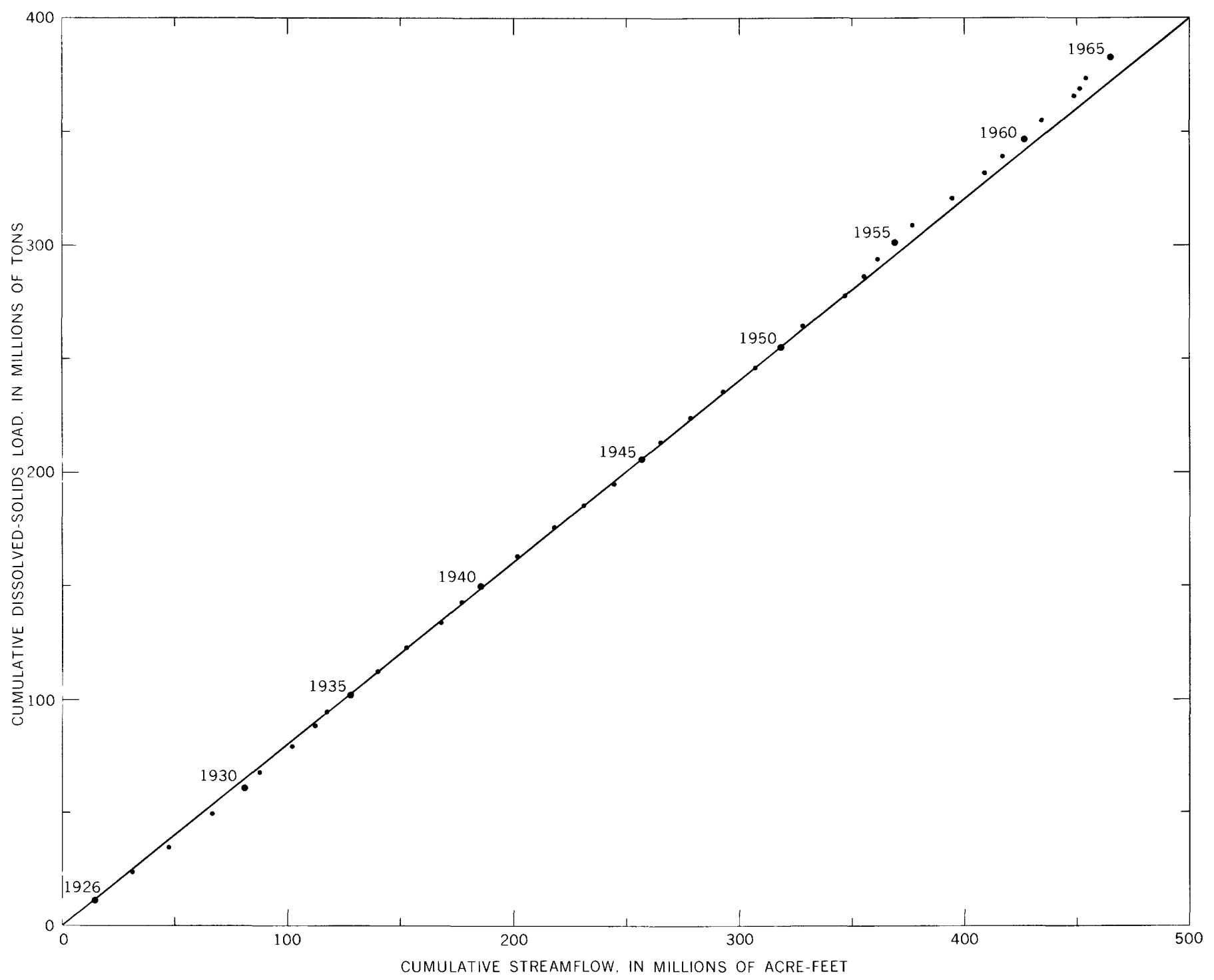

Figure 7.-Double-mass diagram of cumulative dissolved solids load to streamflow, Colorado River at Grand Canyon, $1926-65$.

cated by figure 7 is mainly related to factors causing variation in annual streamflow, parallel differential mass diagrams for the Colorado River at Grand Canyon relating the cumulative departures of annual discharge and annual dissolved-solids loads to their means for the period were plotted together (fig. 8). The joint plotting suggests that any climatic variation affecting streamflow also affects dissolved-solids loads but to somewhat lesser degree.

\section{ANALYSIS OF IONIC LOADS}

One of the most informative methods of appraising the chemical regimen of the Colorado River is analysis of ionic-load variations. The annual loads of the several ions constituting the bulk of the mineral burden of the river vary individually, so the portion of the dissolved-solids burden represented by each ion changes from year to year. Approximate relations of annual constituent loads to discharge near Grand Canyon are indicated by lines on scatter diagrams in figure 9 . The scatter of the points on the three cation and the chloride diagrams are rather well defined. The much greater scatter for sulfate and bicarbonate results from the variability of sources of inflow because some Upper Basin tributaries contribute large sulfate loads compared 


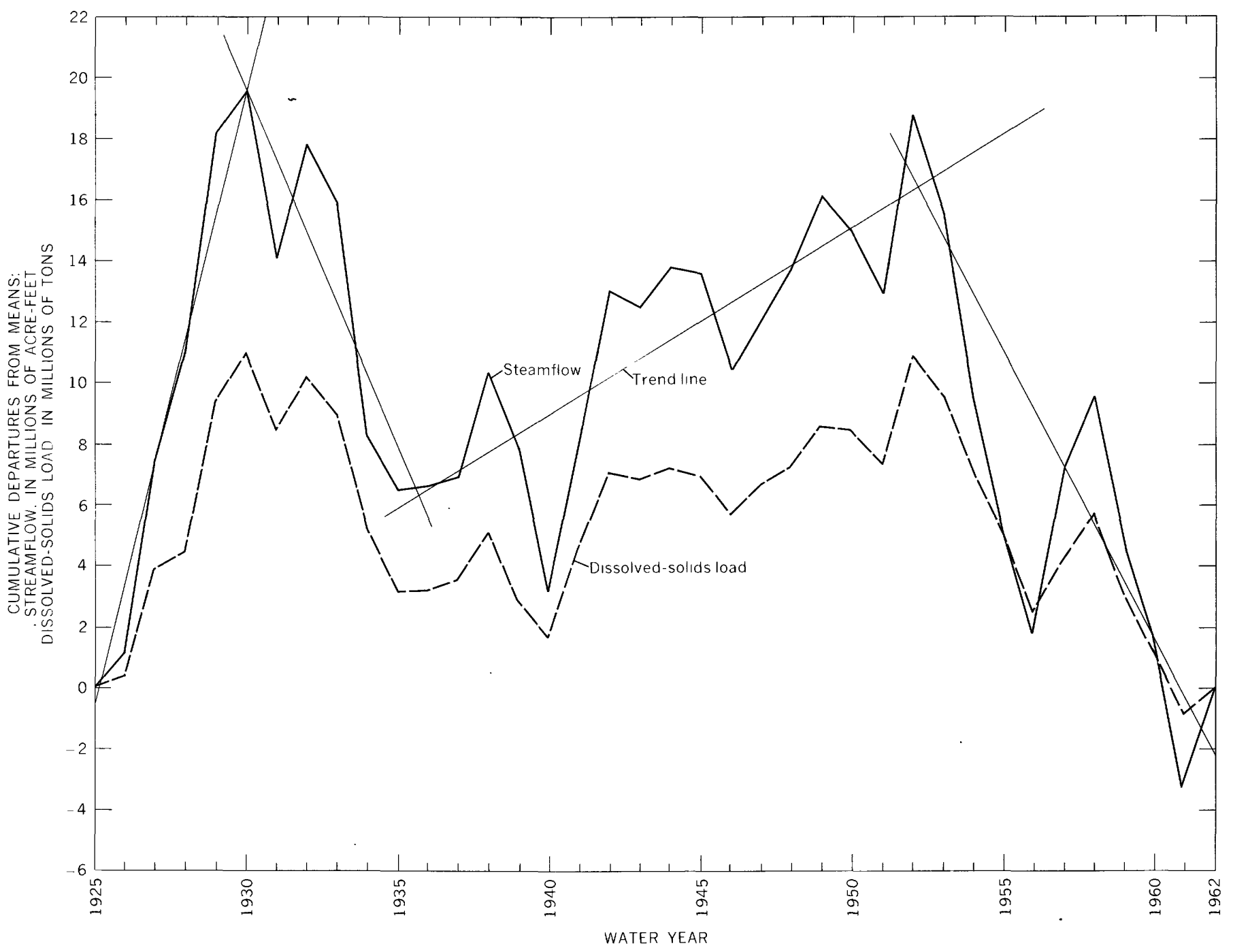

Frgure 8.-Comparative differential mass diagrams for streamflow and dissolved-solids load, Colorado River at Grand Canyon, $1926-62$.

with their bicarbonate loads and others yield much less sulfate in relation to bicarbonate.

Five-year progressive averages of ionic loads near Grand Canyon, compared with those below Hoover Dam in figure 10, emphasize the time-associated changes in the chemical character of water in the river resulting from storage in Lake Mead. The decreasing differences between the 5-year averages at the two points indicate that solution of gypsum (calcium sulfate) and common salt (sodium chloride) was much greater during the early years of reservoir storage than it has been recently. The new holdover storage of water in Lake Powell (which began in 1963) substantially reduced both the flow and the ionic loads downstream, so the last three 5 -year progressive averages are lower than those for 5 -year loads before storage in Lake Powell began.
Accumulated ionic loads have also been used by several authors to show chemical changes in water moving down the river. Howard (1960) compared tonnages of major ionic constituents at Grand Canyon with those below Hoover Dam to estimate chemical precipitation in Lake Mead and solution from its bed. More recently Hill (1965) and Bliss (1965) compared ionic loads expressed in tons-equivalent at Lees Ferry and at Lake Havasu for intervals of 20 years or more and used the comparisons to estimate the future average salinity of Colorado River water at Lake Havasu. Loads in tons-equivalent are computed by dividing the individual ionic loads in tons by their respective chemical-equivalent weights. This method of stating loads has the advantage that equivalency simplifies computations and makes chemical change readily detectable. 

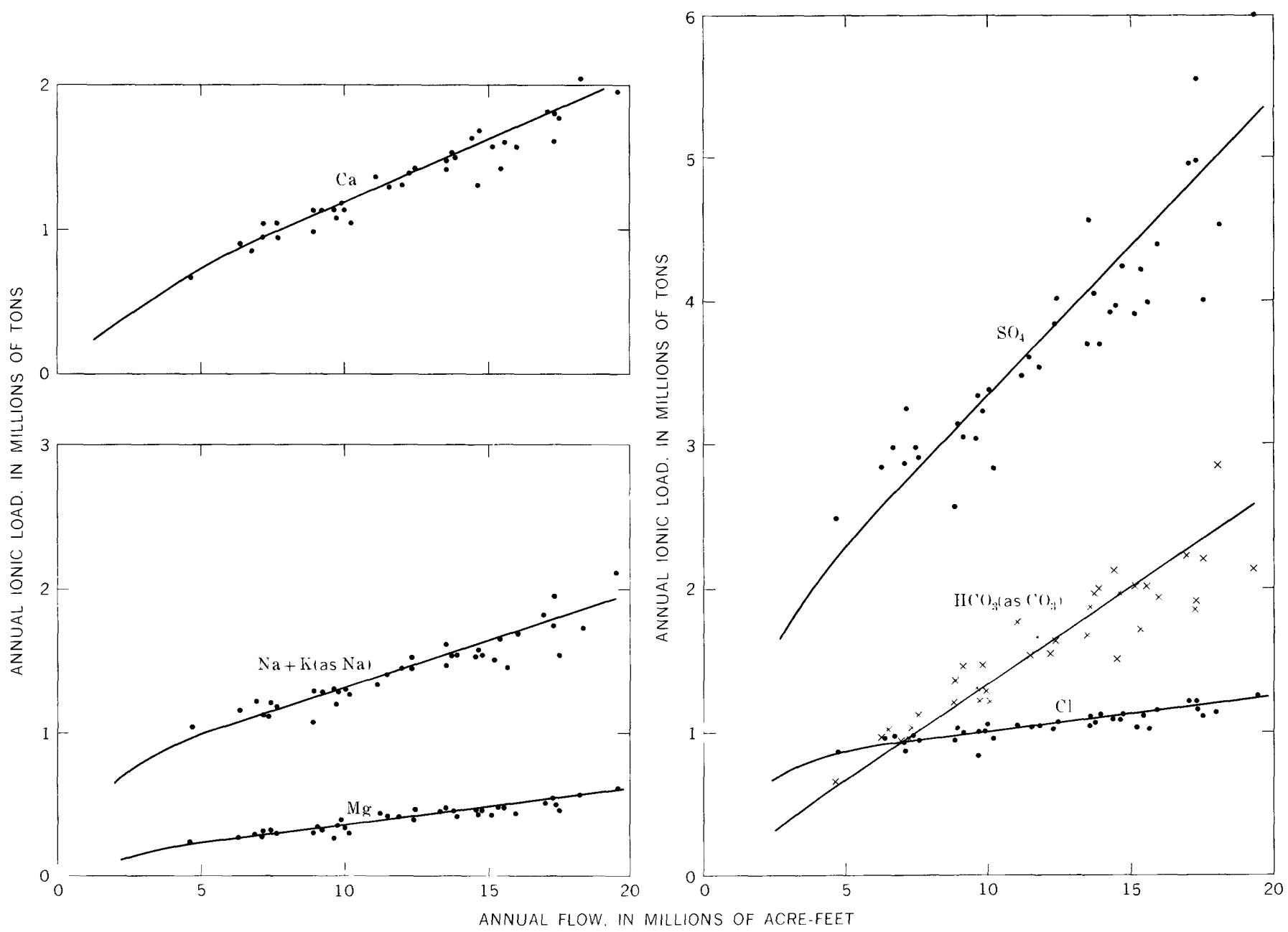

Figure 9.-Approximate relations of annual ionic load of principal constituents to annual flow of Colorado River near Grand Canyon, Ariz., 1926-62.

Comparison of individual ionic loads at widely separated sampling points for single years is not very informative because the time required for water to flow down the river and the modifying effect of the large holdover reservoirs obscure some chemical effects. Better understanding of the pattern of salt accretion and movement in the lower Colorado River is obtained by comparisons of flow and load totals for successive periods of a few years each. To facilitate such comparisons, cumulative totals of streamflow and ionic loads for successive 5-year periods are given on table 7 for the five lower Colorado River sites with long-time chemical-quality records. Also shown are computed gains or losses of ionic loads during the specified periods caused by increments to streamflow, changes in reservoir storage, or diversions out of the Colorado River basin.

Several changes in river-basin development need to be considered in making comparisons between the 5-year periods. For example, during the 25-year period of 1941-65, diversion to the Colorado River aqueduct increased from nearly zero to approximately full capacity of the aqueduct. Lake Mohave filled in the middle of the period. Storage in Lake Powell began early in 1963 and increased nearly every month thereafter. Also, combined irrigated acreage in the Parker, Palo Verde, and Cibola Valleys approximately tripled, so consumptive use of water by irrigation may have tripled. Differences between gains or losses for identical items in table 7 are related to all those developments.

When the 5-year tables are compared, certain loads are found to be more or less proportional to flows, whereas other loads show little relation to flows. Chloride loads above Lake Mead, in particular, appear to be mostly unrelated to flow. For example, the maximum chloride load at Lees Ferry for any of the four periods prior to closure of Glen Canyon Dam was only about 10 percent more than the minimum chloride load even though the maxi- 

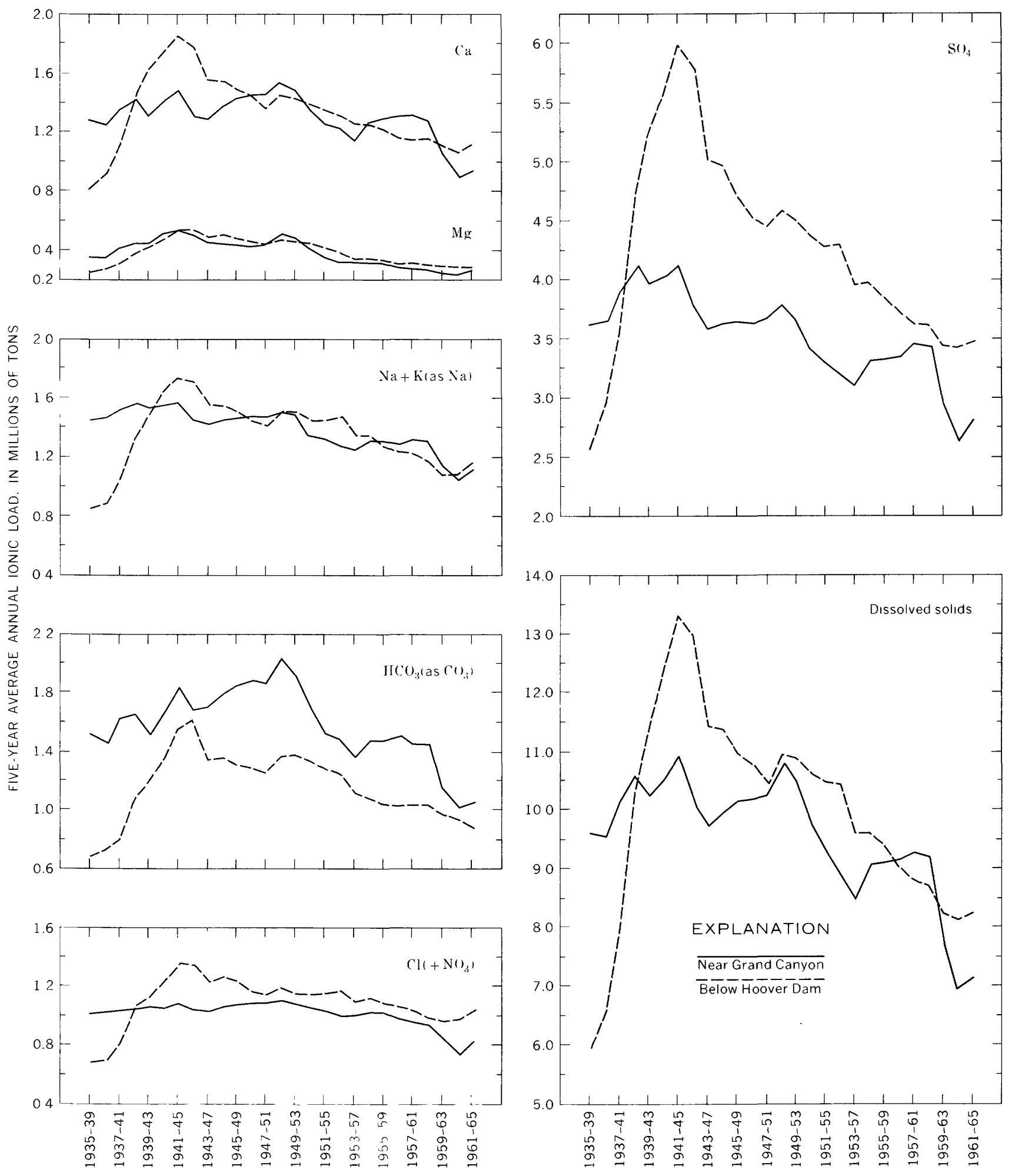

WATER YEARS

FIGURE 10.-Progressive 5-year average ionic and dissolved-solids load, Colorado River near Grand Canyon and below Hoover Dam, 1935-65. 
TABLE 7.-Five-year summary of streamflow and ionic burden of lower Colorado River from Lees Ferry to Imperial Dam [Ionic gains $(+)$ and losses $(-)$ in thousands of tons-equivalent; streamflow and storage change in thousands of acre-feet]

\begin{tabular}{|c|c|c|c|c|c|c|c|c|}
\hline \multirow{2}{*}{ Measuring point or increment } & \multirow{2}{*}{$\begin{array}{l}\text { Total } \\
\text { stream- } \\
\text { flow or } \\
\text { storage } \\
\text { change }\end{array}$} & \multicolumn{3}{|c|}{ Cations } & \multirow{2}{*}{$\begin{array}{l}\text { Total } \\
\text { cations } \\
\text { or } \\
\text { anions }\end{array}$} & \multicolumn{3}{|c|}{ Anions } \\
\hline & & $\mathrm{Ca}$ & $\mathrm{Mg}$ & $\mathrm{Na}+\mathrm{K}$ & & $\mathrm{HCO}_{3}$ & $\mathrm{SO}_{4}$ & $\mathrm{Cl}+\mathrm{NO}_{3}$ \\
\hline \multicolumn{9}{|c|}{$1941-45$} \\
\hline $\begin{array}{l}\text { 1. Lees Ferry } \\
\text { 2. Lees Ferry to Grand Canyon } \\
\text { 4. Grand Canyon } \\
\text { 5. Stand Canyon to Hoover Dame change in Lake Mead } \\
\text { 6. Hoover Dam release } \\
\text { 7. Storage change in Lake Havasu } \\
\text { 8. Hoover Dam to Colorado River } \\
\text { 9. Flow ac Colorado River aqueduct intake } \\
\text { 10. Diversion to Colorado River aqueduct } \\
\text { 11. Parker Dam release } \\
\text { 12. Parker Dam to Imperial Dam } \\
\text { 13. Inflow to Imperial Dam }\end{array}$ & $\begin{array}{r}69,000 \\
+2,030 \\
71,030 \\
-1,054 \\
-476 \\
69,500 \\
-165\end{array}$ & $\begin{array}{r}303.5 \\
+65.1 \\
368.6 \\
+67.7 \\
+28.4 \\
464.7 \\
-. .5\end{array}$ & $\begin{array}{r}177.1 \\
+14.2 \\
191.3 \\
+28.8 \\
-4.5 \\
215.6 \\
-. .6\end{array}$ & $\begin{array}{r}278.8 \\
+54.8 \\
333.6 \\
+35.8 \\
+21.5 \\
390.9 \\
-.4\end{array}$ & $\begin{array}{r}759.4 \\
+134.1 \\
893.5 \\
+132.3 \\
+45.4 \\
1,071.2 \\
-1.5\end{array}$ & $\begin{array}{r}232.9 \\
+69.3 \\
302.2 \\
-49.3 \\
-3.6 \\
249.3 \\
-. .7\end{array}$ & $\begin{array}{r}410.3 \\
+21.2 \\
431.5 \\
+149.3 \\
+43.5 \\
624.5 \\
-.5\end{array}$ & $\begin{array}{r}116.2 \\
+43.6 \\
159.8 \\
+32.1 \\
+5.5 \\
197.4 \\
-.3 \\
+.9 \\
198.0 \\
-.6 \\
197.4 \\
197.4\end{array}$ \\
\hline \multicolumn{9}{|c|}{$1946-50$} \\
\hline $\begin{array}{l}\text { 1. Lees Ferry } \\
\text { 2. Lees Ferry to Grand Canyon } \\
\text { 3. Grand Canyon } \\
\text { 4. Grand Canyon to Hoover Dam } \\
\text { 5. Storage change in Lake Mead } \\
\text { 6. Hoover Dam release } \\
\text { 7. Storage change in Lake Havasu } \\
\text { 8. Hoover Dam to Colorado River } \\
\text { 9queduct intake } \\
\text { 10. Flow at Colorado River aqueduct intake } \\
\text { 11. Piversion to Colorado River aqueduct } \\
\text { 12. Parker Dam release } \\
\text { 13. Inflow to Imperial Dam }\end{array}$ & $\begin{array}{r}61,262 \\
+887 \\
62,149 \\
-2,474 \\
+1,165 \\
60,840 \\
-375\end{array}$ & $\begin{array}{r}299.7 \\
+60.3 \\
360.0 \\
-18.6 \\
+18.2 \\
359.6 \\
-1.8 \\
-23.9 \\
333.9 \\
-4.2 \\
329.7 \\
-. .2 \\
329.5\end{array}$ & $\begin{array}{l}168.1 \\
+8.1 \\
176.5 \\
+3.0 \\
+6.3 \\
185.8 \\
-1.1\end{array}$ & $\begin{array}{r}243.6 \\
+59.9 \\
303.5 \\
+.3 \\
+11.3 \\
315.1 \\
-1.7 \\
+6.9 \\
320.3 \\
-3.8 \\
316.5 \\
+3.6 \\
320.1\end{array}$ & $\begin{array}{r}711.4 \\
+128.6 \\
840.0 \\
-15.3 \\
+35.8 \\
860.5 \\
-4.6 \\
+26.7 \\
829.2 \\
-10.1 \\
819.1 \\
+7.7 \\
826.8\end{array}$ & $\begin{array}{r}233.5 \\
+73.2 \\
306.7 \\
-91.2 \\
+2.8 \\
218.3 \\
-1.4\end{array}$ & $\begin{array}{r}369.9 \\
+9.1 \\
379.0 \\
+67.5 \\
+27.5 \\
+74.0 \\
-2.2\end{array}$ & $\begin{array}{r}108.0 \\
+46.3 \\
154.3 \\
+8.4 \\
+5.5 \\
168.2 \\
-1.0 \\
+.3 \\
167.5 \\
-2.0 \\
165.5 \\
+7.0 \\
172.5\end{array}$ \\
\hline \multicolumn{9}{|c|}{$1951-55$} \\
\hline $\begin{array}{l}\text { 1. Lees Ferry } \\
\text { 2. Lees Ferry to Grand Canyon } \\
\text { 4. Grand Canyon } \\
\text { 4. Grand Canyon to Hoover Dam } \\
\text { 6. Horage change in Lake Mead. Hoover Dam release } \\
\text { 7. Storage changes in Lakes Mohave } \\
\text { and Havasu } \\
\text { 8. Hoover Dam to Colorado River } \\
\text { aqueduct intake } \\
\text { 10. Flow at Colorado River aqueduct intake. } \\
\text { 11. Parker Dam to Colorado River aqueduct. } \\
\text { 12. Parker Dam to Imperial Dam. } \\
\text { 13. Inflow to Imperial Dam }\end{array}$ & $\begin{array}{r}49,955 \\
+732 \\
50,687 \\
-1,238 \\
+7,648 \\
57,097 \\
-832 \\
-1,803 \\
54,462 \\
-1,320 \\
53,142 \\
-3,018 \\
50,124\end{array}$ & $\begin{array}{r}279.2 \\
+34.7 \\
313.9 \\
+5.4 \\
+19.0 \\
338.3 \\
-8.0 \\
-33.2 \\
297.1 \\
-7.3 \\
289.8 \\
+3.9 \\
293.7\end{array}$ & $\begin{array}{r}147.3 \\
+10.9 \\
158.2 \\
-15.6 \\
+22.9 \\
165.5 \\
-2.7 \\
+2.7 \\
165.5 \\
-4.2 \\
161.3 \\
+2.5 \\
163.8\end{array}$ & $\begin{array}{r}232.1 \\
+52.7 \\
284.8 \\
+22.6 \\
+8.1 \\
315.5 \\
-7.8 \\
-8.4 \\
299.3 \\
-7.5 \\
291.8 \\
+22.3 \\
314.1\end{array}$ & $\begin{array}{r}-18.5 \\
-38.9 \\
761.9 \\
-19.0 \\
7+2.9 \\
+28.7 \\
771.6\end{array}$ & $\begin{array}{r}217.8 \\
+43.7 \\
261.5 \\
-75.0 \\
+24.8 \\
211.3 \\
-3.4 \\
-25.1 \\
182.8 \\
-4.5 \\
178.3 \\
+12.3 \\
190.6\end{array}$ & $\begin{array}{r}339.0 \\
+7.8 \\
346.8 \\
+75.4 \\
+22.3 \\
444.5 \\
-10.6 \\
-11.1 \\
422.8 \\
-10.5 \\
412.3 \\
-11.2 \\
411.1\end{array}$ & $\begin{array}{r}101.8 \\
+46.8 \\
148.6 \\
+12.0 \\
+2.9 \\
163.5 \\
-4.5 \\
-2.7 \\
156.3 \\
-4.0 \\
152.3 \\
+17.6 \\
169.9\end{array}$ \\
\hline \multicolumn{9}{|c|}{$1956-60$} \\
\hline $\begin{array}{l}\text { 1. Lees Ferry } \\
\text { 3. Lees Ferry to Grand Canyon } \\
\text { 4. Grand Canyon } \\
\text { 5. Stond Canyon to Hoover Damange in Lake Mead change } \\
\text { 6. Hoover Dam release } \\
\text { 7. Storage changes in Lakes Mohave } \\
\text { and Havasu to Colorado River } \\
\text { 8. Hoover Dam to } \\
\text { 9queduct intake } \\
\text { 10. Dlow at Colorado River aqueduct intake. } \\
\text { 11. Parker Dam release } \\
\text { 12. Parker Dam to Imperial Dam } \\
\text { 13. Inflow to Imperial Dam }\end{array}$ & $\begin{array}{r}-178 \\
-2,215 \\
44,791 \\
-3,107 \\
41,684 \\
-2,791 \\
38,893\end{array}$ & $\begin{array}{r}314.6 \\
+8.1 \\
322.7 \\
-. .1 \\
-30.6 \\
292.0 \\
+1.3 \\
-27.7 \\
265.6 \\
-18.3 \\
247.3 \\
+9.6 \\
256.9\end{array}$ & $\begin{array}{r}136.0 \\
+6.5 \\
142.5 \\
+13.0 \\
-14.0 \\
141.5\end{array}$ & $\begin{array}{r}223.7 \\
+53.9 \\
277.6 \\
+18.4 \\
-24.7 \\
271.3 \\
+1.4 \\
-11.2 \\
261.5 \\
-18.1 \\
243.9 \\
+37.0 \\
280.4\end{array}$ & $\begin{array}{r}674.3 \\
+68.5 \\
742.3 \\
+31.3 \\
-69.3 \\
704.8 \\
+3.2 \\
-36.0 \\
672.0 \\
-46.4 \\
625.6 \\
+36.2 \\
661.8\end{array}$ & $\begin{array}{r}-.2 \\
-26.2 \\
146.4 \\
-10.1 \\
136.3 \\
+10.1 \\
146.4\end{array}$ & $\begin{array}{r}327.2 \\
+17.7 \\
344.9 \\
+73.2 \\
-32.6 \\
385.5 \\
+2.4 \\
-8.7 \\
379.2 \\
-26.2 \\
353.0 \\
+.4 \\
353.4\end{array}$ & $\begin{array}{r}104.1 \\
+44.5 \\
148.6 \\
+10.2 \\
-12.3 \\
146.5 \\
+1.0 \\
-1.1 \\
146.4 \\
-10.1 \\
136.3 \\
+25.7 \\
162.0\end{array}$ \\
\hline
\end{tabular}


TABLE 7.-Five-year summary of streamflow and ionic burden of lower Colorado River from Lees Ferry to Imperial DamContinued

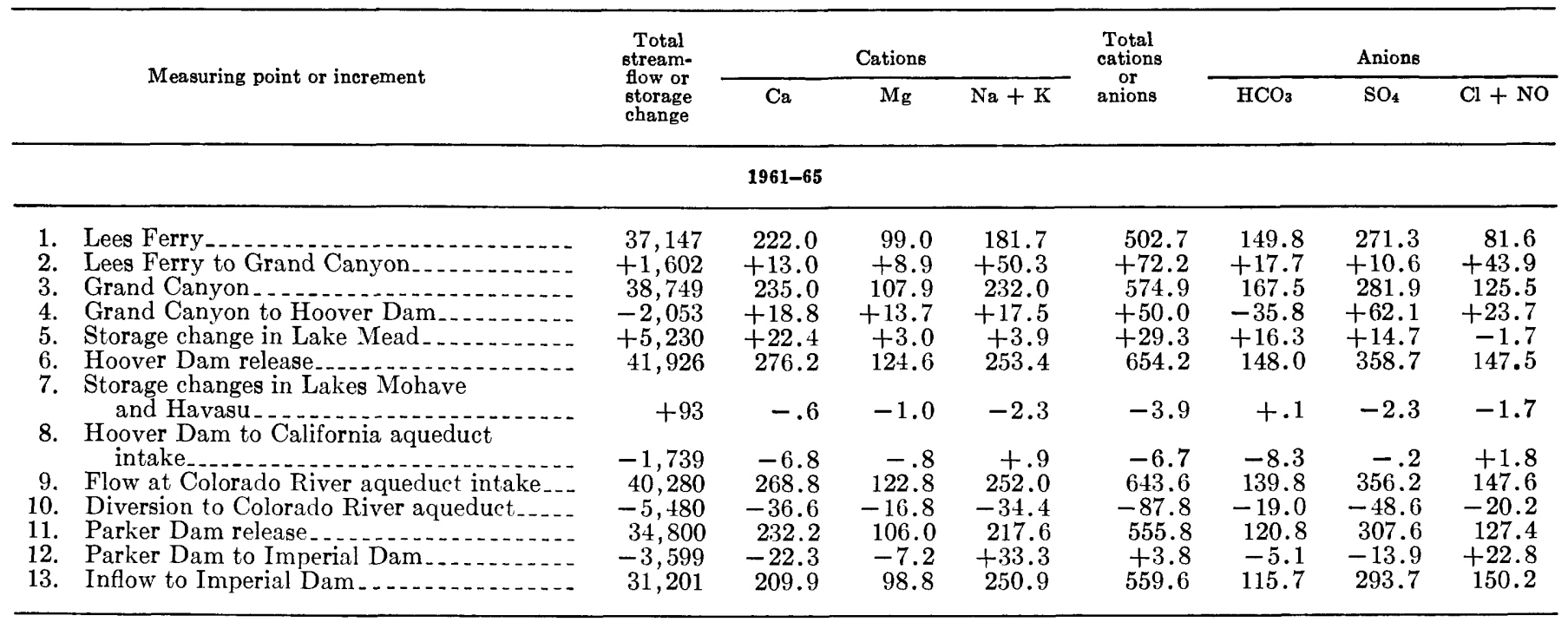

mum flow was 40 percent greater than the minimum. The computed chloride increases between Lees Ferry and Grand Canyon never differed as much as 5 percent from the average for the entire period.

The load summaries not only indicate where fairly constant saline increments enter the river but also help distinguish temporary from continuing chemical effects. For example, all the summaries show decreases in bicarbonate and increases in sulfate in the reach between Grand Canyon and Hoover Dam, which includes Lake Mead. As some bicarbonate must be brought into the lake in Virgin River and other inflow, the consistent decreases in bicarbonate can be explained only as the result of continuing precipitation of calcium carbonate in the lake. The continuing gains in sulfate in the same reach indicate solution of calcium sulfate from the bed of Lake Mead; and because sulfate is also brought into the lake in Virgin River and other inflows, the solution of calcium sulfate is more definitely indicated by the 5-year progressive average loads (fig. 10) than by the increases downriver. Precipitation of calcium carbonate in Lakes Mohave and Havasu is strongly suggested by the continuing decreases in both calcium and bicarbonate between Hoover Dam and Parker Dam.

Comparison of the ionic loads, both by 5-year periods and downriver from Lake Mead, illustrates the changes in the chemical regimen of the lower Colorado River resulting from increasing diversion and use of water. Thus, the steadily increasing diversion of water to the Colorado River aqueduct has contributed to the increase in ionic concentra- tions at Imperial Dam because the quantity of water available for diluting the more concentrated inflows is reduced by the amount of the diversion. In addition, increases in concentrations at Imperial Dam have resulted from the leaching and irrigation of previously uncultivated lands in the Parker and Palo Verde Valleys. Return flows from irrigation in the two valleys contain relatively high concentrations of sodium and chloride leached from the fields, as reflected in the considerable increases in both the loads and concentration of these constituents at Imperial Dam.

\section{AVERAGE ANNUAL IONIC BURDEN OF THE COLORADO RIVER}

Almost inevitably, questions arise as to what is the average mineral burden of the Colorado River and how this burden varies during periods of high or low flow. Generally, it is agreed that the longer the period of record, the better the future values of hydrologic variables can be estimated. Thus a $40-$ year (1926-65) summary of the ionic burden of the Colorado River at Grand Canyon (table 8) by 5-year periods is a better indicator than the previously discussed 25-year summary of the Colorado River mineral burden. In this 40 -year summary the values for the 5-year period 1961-65 are partly estimated, being corrected for the change in storage in Lake Powell and the other upper Colorado River storage reservoirs. Adjustments were made for both the water and the salts retained in the reservoirs.

The 5-year summaries of ionic loads in table 8 were used to compute 5-year, 10-year, 20-year, and 
TABLE 8.-Forty-year summary of ionic burden for Colorado River at Grand Canyon by 5-year periods, 1926-65 [Ionic loads in thousands of tons-equivalent; streamflow in acre-feet]

\begin{tabular}{|c|c|c|c|c|c|c|c|c|c|}
\hline \multirow[t]{2}{*}{ Period } & \multirow[t]{2}{*}{ Total streamflow } & \multicolumn{3}{|c|}{ Cations } & \multirow{2}{*}{$\begin{array}{l}\text { Total } \\
\text { cations } \\
\text { or } \\
\text { anions }\end{array}$} & \multicolumn{3}{|c|}{ Anions } & \multirow{2}{*}{$\frac{\text { Acre ft. }}{\text { Tons-equivalent }}$} \\
\hline & & $\mathrm{Ca}$ & $\mathrm{Mg}$ & $\mathrm{Na}+\mathrm{K}$ & & $\mathrm{HCO}_{3}$ & $\mathrm{SO}_{4}$ & $\mathrm{Cl}+\mathrm{NO}_{3}$ & \\
\hline $\begin{array}{l}\text { 40-year total } \\
\text { Average of }\end{array}$ & $479,849,000$ & $2,657.5$ & $1,314.5$ & $2,450.2$ & $6,422.2$ & $2,079.2$ & $3,110.3$ & $1,232.7$ & 74.7 \\
\hline 5-year periods_ & $59,981,000$ & 332.2 & 164.3 & 306.3 & 802.8 & 259.9 & 388.8 & 154.1 & 74.7 \\
\hline
\end{tabular}

1 Estimated; adjusted for storage in Lake Powell and other upper Colorado River project reservoirs.

40-year average annual ionic loads at Grand Canyon (table 9). The values in table 9 indicate the variability which has occurred for equivalent time intervals in the past, and, therefore, with appropriate considerations of the changes resulting from the works of man, the values can be taken as indicators of what might occur in future. The loads show considerable variation by 5 -year periods, but they trend towards uniformity when averaged for longer periods. They also indicate that with increased storage now available the ionic loads will continue to vary but within a narrow range.
The 5-year average streamflow during 1931-35 was the lowest since the beginning of records in 1896. Therefore, the loads at Grand Canyon during 1931-35 must have been close to the minimum which can be expected during any future 5-year period, if adjustments are made for the effects of Upper Basin reservoirs.

Ionic burden at Lees Ferry as determined by other investigators

Although both the length and completeness of sampling make the Grand Canyon record the best

TABLE 9.-Averages of streamflow and ionic burden of Colorado River at Grand Canyon for different periods [Averages assume no storage in upper Colorado River Storage project reservoirs. Ionic loads in thousands of tons-equivalent; streamflow in acre-feet]

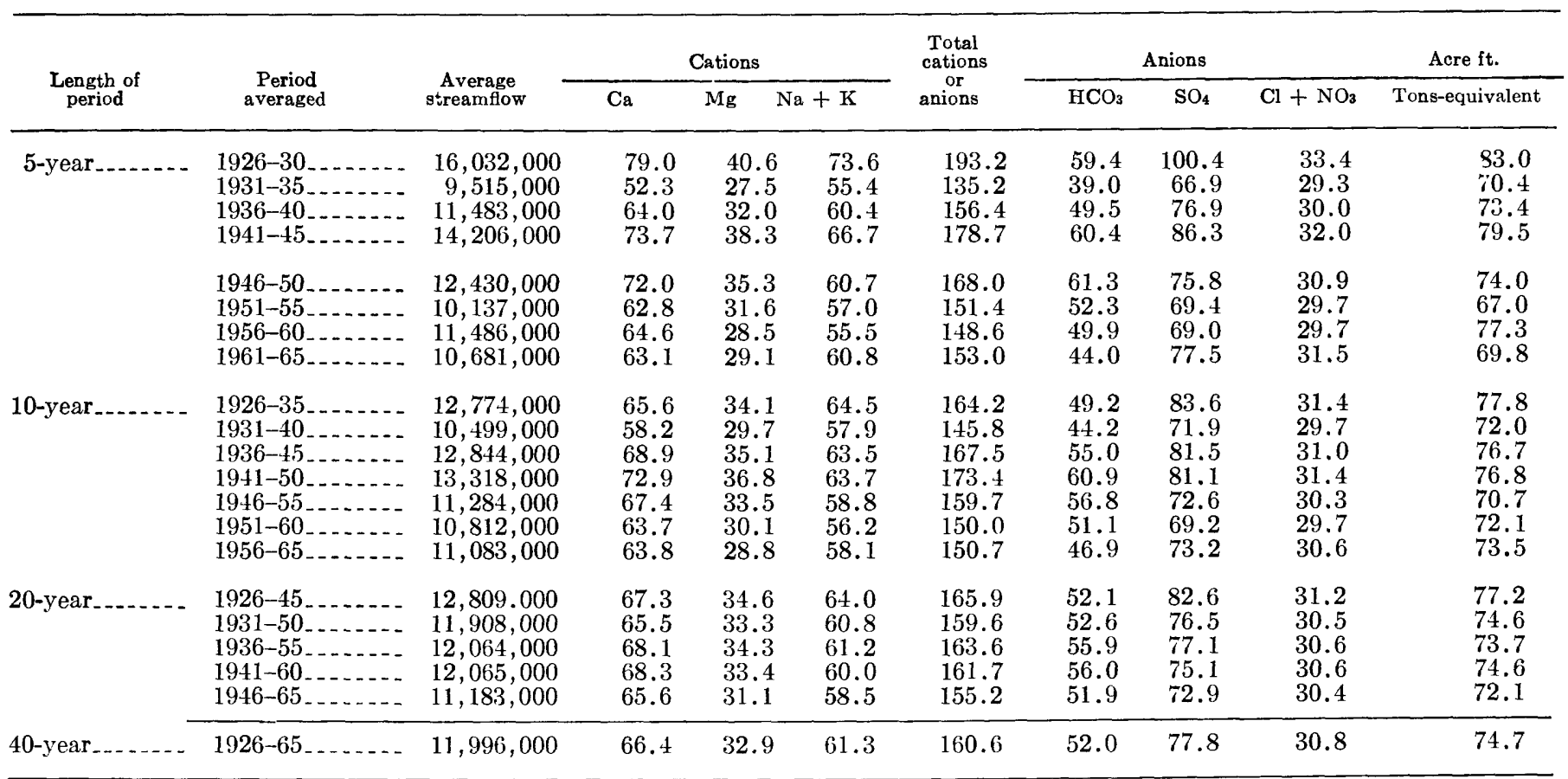

Nore.-Range in total cations and anions: 5-year averages, 135.2; 10-year averages, 145.8-173.4; 20-year averages, 155.2-165.9. 
basis for describing the ionic burden of the lower Colorado River, previously published computations of this burden have been based on the Lees Ferry record. Hill (1965) computed the ionic burden at Lees Ferry for 1941-60 from the weighted-average concentrations as published in water-supply papers of the U.S. Geological Survey ("Quality of Surface Waters in the United States") without correcting yearly averages for years with incomplete records but instead by estimating for missing years. Bliss (1965) estimated data for years of no record by correlation and computed an average ionic burden for 1930-60. Iorns, Hembree and Oakland (1965) computed a weighted average for the period 1914-57 from a table of average concentrations for selected flow ranges and a flow-duration curve. Table 10 gives the average loads at Lees Ferry published by the above individuals and the weighted averages computed for the present study. The weighted averages include periods during which sampling was done only at Grand Canyon. The Grand Canyon record for these periods was adjusted to a probable record at Lees Ferry on the basis of the average gain of minerals between the two stations during periods when both records were complete. Unfortunately, this procedure cannot be used to compute concentration for the period Iorns uses because no sampling occurred before 1926; however, the estimate for 1926-65 was found to be comparable with Iorns' estimate for 1914-57.

\section{IONIC BUDGET OF THE COLORADO RIVER FROM LEES FERRY TO IMPERIAL DAM, 1961-65}

A detailed ionic budget is one of the most useful aids to understanding the chemical regimen of the lower Colorado River. Such a budget is a summary of determined or estimated ionic loads carried past key river points in downstream order. The budget includes estimates of gains from principal tributaries and of losses to major diversions, as well as computations of gains and losses in the storage reservoirs. An ionic budget serves both as an identification of principal sources of increments to the ionic loads carried by the river and as a base for predicting what might happen to water quality if present diversions are either expanded or reduced or if new diversions are made from the river.

Comparison of the weighted averages in table 10 indicates that considerably more variation of period loads at Lees Ferry results from the choice of base period than from the manner in which missing records are estimated. It also appears from the table that Hill, Bliss, and Iorns, Hembree and Oakland may have understated the sulfate burden at Lees Ferry by a small percentage.

An ionic budget computed for a single year has questionable value because the flow pattern of any individual year may not be representative of the usual amounts of water in the various river reaches considered, because passage of water through storage reservoirs produces slow chemical changes not easily determinable on an annual basis, and because flows of individual tributaries may be highly abnormal in any selected year. Also, the ionic contributions of the various tributaries cannot generally be defined in terms of specific years because sampling studies on different tributaries are generally not concurrent and are of unequal length and intensity. On the other hand, an ionic budget prepared for a long period has questionable value because of the many changes in river regimen resulting from Upper Basin developments, construction of Upper and Lower Basin storage reservoirs, and continuing changes in amounts of diversion and return flow in the Lower Basin. As a result of such changes, long-time averages of ionic loads are likely to be quite different from future average annual loads. Thus, ionic budgets prepared for a long period of a few recent years appear to be most meaningful. Accordingly, a detailed ionic budget for the Colorado River reach extending from Lees Ferry to Imperial Dam is presented only for the 5-year period 1961-65.

TABLE 10.-Comparative computations of average annual streamflow and ionic burden for Colorado River at Lees Ferry [Ionic loads in thousands of tons-equivalent. Streamflow in acre-feet]

\begin{tabular}{|c|c|c|c|c|c|c|c|c|c|}
\hline \multirow{2}{*}{$\begin{array}{l}\text { Period } \\
\text { summarized }\end{array}$} & \multirow[t]{2}{*}{ Authority } & \multirow{2}{*}{$\begin{array}{c}\text { Average } \\
\text { streamflow }\end{array}$} & \multicolumn{3}{|c|}{ Cations } & \multirow{2}{*}{$\begin{array}{c}\text { Total } \\
\text { cations } \\
\text { or } \\
\text { anions }\end{array}$} & \multicolumn{3}{|c|}{ Anions } \\
\hline & & & $\mathrm{Ca}$ & $\mathrm{Mg}$ & $\mathrm{Na}+\mathrm{K}$ & & $\mathrm{HCO}_{3}$ & $\mathrm{SO}_{4}$ & $\mathrm{Cl}+\mathrm{NO}_{3}$ \\
\hline $1941-60 \ldots \ldots$ & Irelan (this report) $\ldots$ & $11,821,000$ & 59.9 & 31.4 & 48.9 & 140.2 & 46.4 & 72.3 & 21.5 \\
\hline $1930-60 \ldots \ldots$ & Bliss $(1965)$ & $11,314,000$ & 56.3 & 30.1 & 47.5 & 133.9 & 43.9 & 68.6 & 21.4 \\
\hline $1930-60 \ldots \ldots$ & Irelan (this report) $\ldots$ & $11,314,000$ & 56.8 & 30.4 & 48.5 & 135.7 & 42.6 & 71.9 & 21.2 \\
\hline $1926-65 \ldots \ldots$ & Irelan (this report) $\ldots$ & $11,689,000$ & 58.0 & 30.9 & 50.2 & 139.1 & 42.4 & 75.0 & 21.7 \\
\hline
\end{tabular}


The items in the ionic budget were computed from a variety of source analyses. Ionic loads at the five principal sampling sites on the river were computed from the previously described weighted averages. Ionic loads at other sites were obtained by allowing for gains from tributaries, losses by diversions, and gains or losses caused by changes in reservoir levels. Ionic loads contributed by tributaries were computed mostly from chemical analyses published in various issues of the annual water-supply series of the U.S. Geological Survey "Quality of Surface Waters of the United States." Some of these were computed from weighted averages, and others from unweighted analyses selected as the most representative for the period 1961-65. Some ionic loads, however, were computed from incomplete analyses corrected in a variety of ways. Ionic loads in drain waters were computed from unpublished analyses obtained during this investigation. The analyses used to represent the tributaries and drains in the ionic budget are given in table 11 . The following paragraphs give explanations of the sources of analyses, the computations made from them, the significance of the sampled flows, and the changes computed between sampling sites or tributaries.

\section{LEES FERRY}

The use of Lees Ferry as a reference point in other Colorado River studies makes this a desirable point at which to begin an ionic budget. The average flow and ionic loads at Lees Ferry during 1961-65, however, are not comparable with those of earlier 5-year periods because storage of water in Lake Powell and other upper Colorado River reservoirs began during the period. On September 30, 1965, a total of 11,724,000 acre-feet of water was held in the new upper Colorado River storage project reservoirs, and most of it accumulated after March 13, 1963, when storage began in Lake Powell. In addition, approximately one-fourth of the inflow to Lake Powell is estimated to have been retained in bank storage. Thus, in about $21 / 2$ years about 15 million acre-feet of water and its dissolved ionic loads, which previously would have flowed past Lees Ferry, were retained upstream. Yet, the water being released from Lake Powell on September 30, 1965, had a substantially lower concentration than the average at Lees Ferry during the 1961-65 period. This may have been the result of uneven mixing of the water in the lake, or it may have resulted from precipitation of calcium carbonate in the stored water.

To allow for the storage effects, the 5-year flows and ionic loads determined from records at Lees Ferry for 1961-65 were adjusted for the new upriver storage, by assuming that all the stored water had the concentration of Lake Powell releases in September 1965. The ionic budget (table 12) begins with these adjusted quantities. The estimated average flow and loads retained in storage, including bank storage, are given next. Following that, the table gives the flow and loads at Lees Ferry as they actually were measured.

\section{PARIA RIVER}

In the Colorado River Compact the Paria River basin is considered part of the Upper Basin. The flow and ionic loads of the Colorado River at the compact point, however, include contributions from the Paria River. Therefore, it is necessary to add these contributions to those of the Colorado River at Lees Ferry to obtain the quantities passing from the Upper Basin to the Lower Basin. Chemical analyses of water samples collected periodically from the Paria River near its mouth are reported in some of

TABLE 11.-Representative analyses of tributary inflow to lower Colorado River between Lees Ferry and Imperial Dam [Results in milligrams per liter unless otherwise indicated]

\begin{tabular}{|c|c|c|c|c|c|c|c|c|c|c|c|c|}
\hline No. & Source & $\begin{array}{c}\text { Date } \\
\text { (* weighted } \\
\text { average) }\end{array}$ & 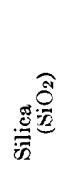 & : & 苞 & 䒿芯 & 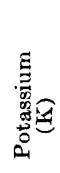 & 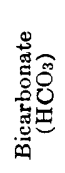 & 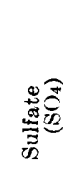 & 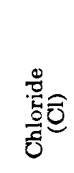 & 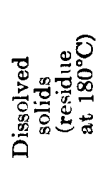 & 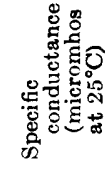 \\
\hline 1. & Paria River at Lees Ferry & $1914-57 *$ & & 121 & 57 & 134 & & 203 & 608 & 23 & 1,090 & 1,480 \\
\hline 2. & Little Colorado River at Cameron, Ariz. & $1952 *$ & $1 \overline{6}$ & 29 & 5 & 98 & & 162 & 57 & 80 & 368 & 624 \\
\hline 3. & Blue Springs & June $21,1965 \ldots$ & 17 & 91 & 64 & 793 & & 396 & 163 & 1,220 & 2,500 & 4,520 \\
\hline 4. & Bright Angel Creek at mouth & Aug. $4,1952 \ldots$ & 8 & 42 & 21 & 4.9 & & 223 & 14 & 3 & 203 & 347 \\
\hline 5. & Tapeats Creek at mouth & June $25,1965$. & & 36 & 11 & 4.1 & & I 68 & 3.8 & 1.3 & 147 & 267 \\
\hline 6. & Havasu Springs & ()ct. $20,1950 \ldots$ & 18 & 133 & 48 & 27 & & 58 & 36 & 48 & 602 & 1,030 \\
\hline 7. & Virgin River at Littlefield, Ariz. & $1961 *$ & 20 & 364 & 88 & 263 & & 314 & 1,060 & 330 & 2,160 & 3,040 \\
\hline$\ddot{8}$. & Bill Williams River at Planet, Ariz. & Aug. $8,1931 \ldots$ & 36 & 45 & 11 & 65 & & 228 & 41 & 46 & 362 & \\
\hline 9. & Colorado Indian Reservation, Upper Main Drain-- & May $26,1905 \ldots$ & 19 & 138 & 43 & 183 & & 256 & 450 & 170 & 1,130 & 1,780 \\
\hline 10. & Colorado Indian Reservation, Palo Verde Drain..- & ()ct. $24,1962 \ldots$ & 20 & 92 & 30 & 10 & & 17 & 292 & 95 & 722 & 1,180 \\
\hline 11. & Colorado Indian Reservation, Lower Main Drain.- & Oct. $15,1964 \ldots$ & 22 & 178 & $6 \tilde{5}$ & 391 & & 28 & 675 & 442 & 1,920 & 2,970 \\
\hline 12. & Palo Verde District, Olive Lake Drain & Dec. $13,1963 \ldots$ & 14 & 130 & 40 & 145 & & 256 & 375 & 144 & 930 & 1,550 \\
\hline 13. & Palo Verde District, outfall drain & Jan. $10,1964 \ldots$ & 14 & 132 & 45 & 371 & & 292 & 525 & 380 & 1,570 & 2,610 \\
\hline
\end{tabular}


TABLE 12.-Average annual streamflow and ionic burden of the Colorado River, Lees Ferry to Imperial Dam, 1961-65 [Streamflow in acre-feet; ionic gains $(+)$ and losses $(-)$ in thousands of tons-equivalent]

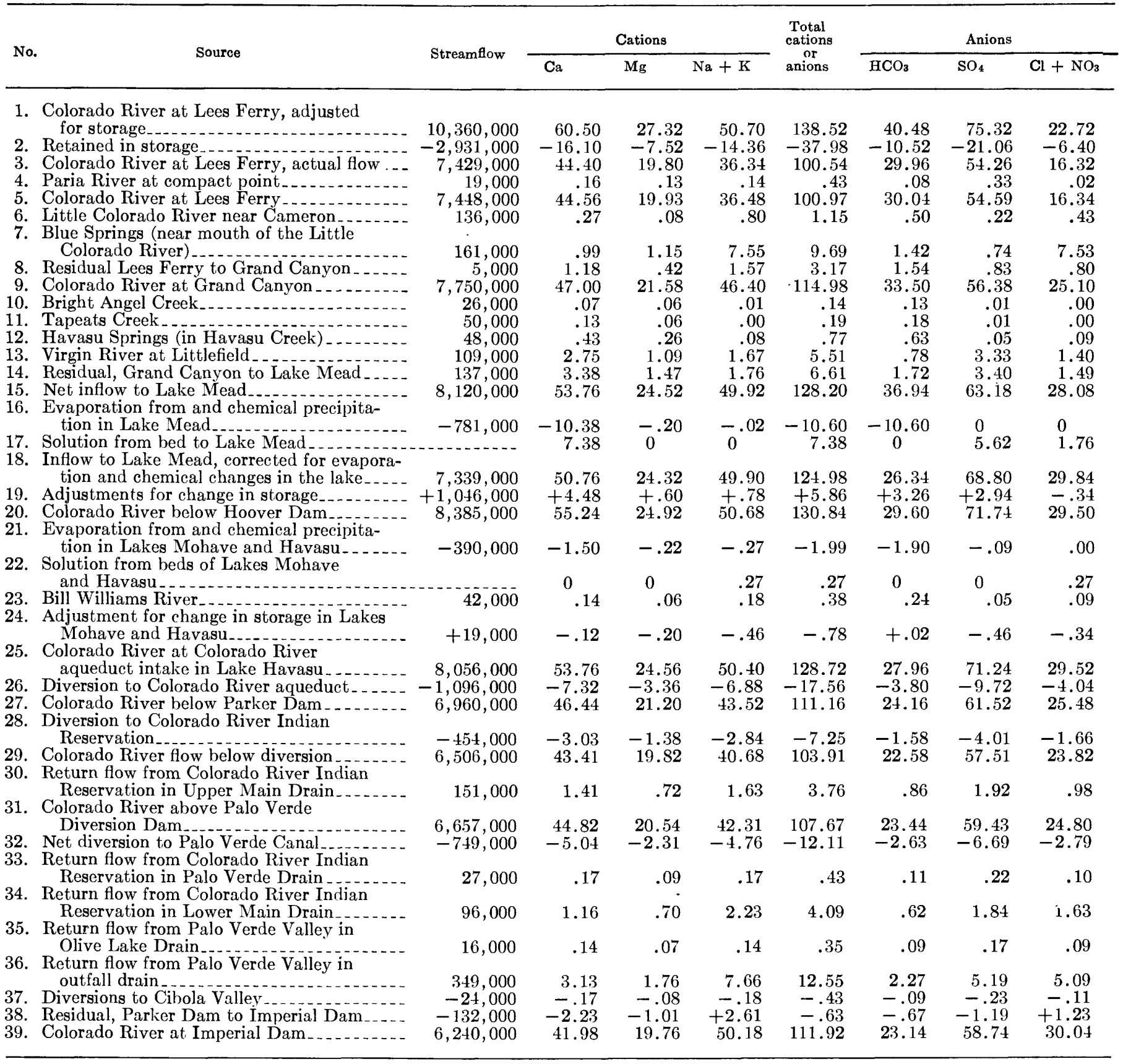

the annual water-supply papers. Iorns, Hembree, and Oakland (1965) prepared a mineral-concentration duration table which related the salinity of the river water to discharge. The analysis of Paria River water given in table 11 was obtained from the duration table and corresponds to the 1961-65 average flow. Paria River water is primarily a calcium sulfatr solution, low in chloride but containing considerable sodium bicarbonate. The computed loads (table 12, item 4) indicate that the Paria River has a negligible effect on the salinity of Colorado River water downstream.

\section{LITTLE COLORADO RIVER}

An important segment of the flow of the Little Colorado River, the largest tributary entering the Colorado between Lees Ferry and Imperial Dam, is the discharge from Blue Springs, which are in the 
river channel a few miles above its mouth. In the ionic budget, Little Colorado River refers to the river flow above the springs.

Little Colorado River was sampled for several years at Cameron Ariz., about 45 miles above its mouth, where it is dry for extended periods nearly every year. Because of the uncertainty of the adequacy of sampling during early portions of some flow periods, the water-supply papers give weightedaverage concentrations only for the year 1952, when the river flow was more than twice the average annual flow. Study of the sampling records, however, indicates that the 1952 analyses were not greatly different from those obtained in the other years represented by sampling. Consequently, the 1961-65 average load for the Little Colorado River was computed by multiplying the 1952 measured load by the ratio of the 1961-65 average flow to the 1952 flow. This procedure probably results in the Little Colorado River's being represented by an analysis somewhat lower in concentration than the true 1961-65 weighted average and by a somewhat greater load than the true load for the period.

The water of Little Colorado River above Blue Springs is less concentrated than that of the Colorado River at Lees Ferry. Therefore, in years of substantial discharge the Little Colorado River water may moderately reduce the usual gain in dissolvedsolids concentration between Lees Ferry and Grand Canyon. The average flow during 1961-65 was too small for this reduction to be significant.

\section{BLUE SPRINGS}

Blue Springs here refers to the entire group of springs near the mouth of the Little Colorado River and not to the single large spring sometimes referred to as Blue Springs. Although samples of water obtained from different springs in the group have varied in composition, analyses of samples of mixed outflow obtained near the mouth of the river have indicated nearly uniform composition of the mixed flow. An analysis of one such sample taken when the Little Colorado River above the springs was dry represents the combined spring flow as shown in tables 11 and 12. Measurements of discharge made at the mouth of the Little Colorado River when the river was dry at Cameron indicate a nearly constant spring discharge of about 161,000 acre-feet per year. Discharge from Blue Springs apparently accounts for most of the increases in ionic concentrations in Colorado River water between Lees Ferry and Grand Canyon. Most of the increment of the mineral load of the Colorado River derived from the springs is sodium chloride; the computations indicate that the springs add more sodium chloride to the river's mineral burden than all the other tributaries between Lees Ferry and Imperial Dam combined.

\section{UNMEASURED INFLOW FROM LEES FERRY TO GRAND CANYON}

Several small tributaries with unknown annual discharges enter the Colorado River between Lees Ferry and Grand Canyon. A residual estimate of their combined flow, less river evaporation, is obtained by subtracting the sum of the Colorado River flow at Lees Ferry, the Paria River flow, the Little Colorado River flow at Cameron, and the Blue Spring discharge from the recorded flow at Grand Canyon. The ionic load residuals are obtained by a similar computation, but because the evaporation is unknown, the average concentration of the inflow cannot be approximated. The mineral increment contributed by inflow and possibly by solution from the streambed has about the general composition of limestone water, with calcium and magnesium bicarbonates constituting about half the increment and sodium sulfate and sodium chloride constituting nearly equal parts of the remainder.

\section{GRAND CANYON}

The significance of the Grand Canyon station as a record point has been discussed previously. During the 5-year period 1961-65 when flow below Lake Powell was partly controlled, the percentage of increase in flow between Lees Ferry and Grand Canyon was about one-third of the percentage of increase in mineral burden.

\section{BRIGHT ANGEL CREEK}

Most of the flow of Bright Angel Creek originates in springs which emerge near the base of the Muav Limestone, several thousand feet above the Colorado River but also several thousand feet below the north rim of the Grand Canyon. Water is pumped from Roaring Springs, one of the largest of the Bright Angel Creek sources, to supply facilities on the north rim of the Grand Canyon. Intermittent sampling near its mouth has shown that the ordinary flow of the creek is always low in mineral content and that most of the dissolved minerals are calcium bicarbonate. The creek adds an insignificant amount of minerals to the load of the Colorado River and whenever in flood has a considerable temporary diluting effect on the river water. 


\section{TAPEATS CREEK}

Entering the Colorado River about 45 miles below the mouth of Bright Angel Creek, Tapeats Creek is fed by springs in the Muav Limestone. Johnson and Sanderson (1968) gave analyses of the creek water, and on the basis of a few discharge measurements they estimated the discharge as a little less than twice the discharge of Bright Angel Creek. The Tapeats Creek water is similar in composition to but even less mineralized than the Bright Angel Creek water.

\section{HAVASU CREEK}

Most of the flow of Havasu Creek, the largest tributary on the south side of Grand Canyon, originates from Havasu Springs and has been measured only occasionally. By assuming that a 1950 analysis of the spring water (table 11) is representative of the creek's mineral contribution, it has been determined that Havasu Creek adds mostly calcium bicarbonate to the load of the Colorado River. As Havasu Creek is known to be depositing travertine below the springs, it is possible that the computed additions to the mineral burden of the Colorado River (table 12, item 12) are high.

\section{VIRGIN RIVER}

There is considerable uncertainty in estimating increments of ionic constituents added to the Colorado River by the Virgin River. Several years of chemical-quality records were obtained at Littlefield, Ariz., about 40 miles above the mouth of the Virgin River, but because of diversions for irrigation downstream, the mineral burden at Littlefield that actually reaches the Colorado River is somewhat uncertain. It is assumed herein, however, that the water and salts passing Littlefield represent the flow into the river. The weighted average for 1952 was used to represent the Virgin River concentrations because the 1952 discharge was almost the same as the 5-year average for 1961-65. Virgin River water is high in calcium sulfate, but the river also carries substantial amounts of sodium chloride which enter it from springs in Utah.

\section{UNMEASURED INFLOW BETWEEN GRAND CANYON AND HOOVER DAM}

Simultaneous solution of lakebed minerals and chemical precipitation of calcium carbonate in Lake Mead make ionic budgeting of the reach between Grand Canyon and Hoover Dam speculative. Mineral increments entering the reach from the four major tributaries, Bright Angel Creek, Tapeats Creek, Havasu Springs, and Virgin River, have been estimated from chemical and discharge information, but increments possibly as large derived from many small springs and minor tributaries cannot be estimated directly. Also, the ionic increments in the unmeasured inflow cannot be estimated by differences as was done for the reach between Lees Ferry and Grand Canyon because the gains and losses in Lake Mead constitute part of the unmeasured differences; so the arbitrary assumption was made in preparing table 12 that the combined increments from all unmeasured inflow (item 14) are equal to the sums of the measured increments from the four tributaries. The volume of the unmeasured streamflow was computed by subtracting the sum of the Colorado River flow at Grand Canyon and the flows of the four named tributaries from the net inflow to Lake Mead (determined as explained in the next section).

The sizes of the ionic increments derived under this assumption seem reasonable, considering the quantities of ionic loads entering other reaches of the river. The unmeasured ionic load increments might, however, reasonably have been estimated to be as little as one-half or as much as double the tabulated quantities.

Thus, the quantities of flows and ionic loads entering Lake Mead (table 12, item 15) are sums of those for the river at Grand Canyon, for the four tributaries, and for the just-described residuals.

\section{CHEMICAL CHANGES IN LAKE MEAD}

It has been known for many years that chemical precipitation of calcium carbonate is nearly continuous in the body of Lake Mead and that at the same time other minerals are continuously being dissolved from some of the sedimentary formations that constitute part of its bed. The mineral budgeting makes possible quantitative appraisals of these two chemical processes.

The 5-year streamflow and ionic-load averages below Hoover Dam (table 12, item 20) were determined from the annual streamflow and chemical-quality records. Adjustments (item 19) were made to allow for a net decline in lake contents during the 5 years and for a corresponding decline of mineral contents by assuming that chemical analyses of water samples taken at the beginning and end of the 5-year period represented the mineral contents of the entire lake when sampled. The differences between these last two sets of computations (item 18) were as- 
sumed to represent the 5-year average effective flows and loads at Hoover Dam-that is, the average flows and loads which would have occurred if there had been a constant lake level during the period instead of a net decline. The average net inflow to Lake Mead (item 15), used previously to compute the unmeasured inflow between Grand Canyon and Hoover Dam, was then computed as the sum of the effective annual flow at Hoover Dam and the average of the evaporation losses reported for the lake.

The differences between the ionic loads computed for the net inflow to Lake Mead (item 15) and the effective flow at Hoover Dam (item 18) must represent either chemical precipitation or mineral solution. In the mineral budget, as prepared, anion dominance was assumed to determine whether precipitation or solution had occurred. Thus, the decrease in bicarbonate loads computed for the two flows indicates precipitation of calcium carbonate in the lake. In contrast, the computed gains of both sulfate and chloride must have been the result of solution of lakebed minerals. In the ionic budget the cation gains and losses were arbitrarily assigned in such a way that the bicarbonate losses caused by precipitation (item 16) and the sulfate and chloride gains resulting from solution (item 17) were balanced ionically; thus no unaccountable gains and losses resulted between points with measured loads. The fact that calcium changes were sufficient to account for nearly all the cation gains and losses, within small errors, suggests that the assumptions were reasonable.

During the 5 years 1961-65, the indicated chemical precipitation in Lake Mead (item 16) somewhat exceeded the estimated solution of minerals from its bed (item 17). Hence, the lake storage influenced the chemical composition of the released water more than it affected the total mineral load. During some earlier periods, however, the load was markedly affected by the lake. (See fig. 10.)

\section{BILL WILLIAMS RIVER}

From Hoover Dam to Imperial Dam the Colorado River flows through a succession of narrow canyons and wide valleys and has only one sizeable tributary - the Bill Williams River. Although this tributary river contributes a few thousand acre-feet to the Colorado River every year and a few hundred thousand acre-feet during rare years of extraordinary flow, flow is perennial only in a few short reaches; at the mouth of the river the flow is intermittent. The Bill Williams was sampled intermittently at Planet, Ariz., for many years, but averages and loads were never computed. Study of the analyses indicates that the water in this river is always much lower in mineral content than the Colorado River water. It nearly always contains less than $450 \mathrm{mg} / \mathrm{l}$ dissolved solids, with bicarbonate the major constituent. The Bill Williams River was not sampled during 1961-65. Accordingly, it is represented by an analysis (table 11) selected from the old record (Howard, 1955). Load computations (table 12, item 23) indicate that the Bill Williams has negligible effect on the mineral burden of the Colorado River water below its mouth.

\section{CHEMICAL CHANGES IN LAKES MOHAVE AND HAVASU}

The quality-of-water records at Hoover and Parker Dams show the chemical character of river water passing them. By reasoning similar to that used to establish the effects of Lake Mead, the combined effects of Lakes Mohave and Havasu on Colorado River loads during 1961-65 were established. The computations resulted in small adjustments (table 12 , item 24) in the water and mineral contents of the two lakes. Evaporation and calcium carbonate precipitation (item 21) together account for most of the chemical changes occurring between the two dams. The amount of increase in mineral load (item 22) seems to be so small that it is insignificant and well within the overall errors of the mineral budget. Evidently, there are no major sources of minerals which are unaccounted for. Consequently, no residual was included for this reach in table 12 .

\section{DIVERSION TO COLORADO RIVER AQUEDUCT}

The Colorado River aqueduct intake, in Lake Havasu, is the uppermost point in the lower Colorado River where relatively large volumes of water are now diverted. Although pumping of water through the aqueduct to cities of southern California began in 1939, the amounts diverted were at; first quite small compared with the flow of the river and did not reach 5 percent of the annual river flow until 1955, when pumping was 413,000 acre-feet. Thereafter, the annual diversion increased more rapidly; during the 5-year period 1961-65 it averaged more than 1 million acre-feet and increased every year except 1962. The recent large diversion to the California aqueduct has an important effect on the salinity of Colorado River water at Imperial Dam because it reduces the amount of water available to dilute the somewhat saline return flows from the irrigated areas in the Parker and Palo Verde Valleys. Only part of the increase in concentration at Imperial Dam, however, is a result of the increased diversion through the aqueduct. Part of the increase 
is a result of a rapid expansion of irrigation in the two valleys and the consequent increases in the volumes of saline returns.

\section{PARKER DAM TO IMPERIAL DAM}

Between Parker and Imperial Dams the Colorado River flows through the Parker, Palo Verde, and Cibola Valleys, which together form a continuous valley referred to in some early reports as the Great Colorado Valley. Diversions to irrigate the Parker Valley are made at Headgate Rock Dam, a few miles north of Parker, Ariz. Diversions to irrigate the Palo Verde Valley are made at the Palo Verde Dam, several miles north of Blythe, Calif. Irrigation return flows from Parker Valley reenter the Colorado River both above and below Palo Verde Dam. Return flows from irrigation in Palo Verde Valley reenter the river opposite Cibola Valley. Water is pumped to irrigate areas in Cibola Valley from the river and from wells in the flood plain. As the alluvial aquifer is largely recharged from the river, the pumpage from the wells is a draft on the river. There are no surface drains in the Cibola Valley. As much as 20,000 acres may have been added to the irrigated area in the 15 years prior to 1965 . Leaching of soluble salts from new lands not previously irrigated has probably resulted in substantial additions to the Colorado River's mineral burden at Imperial Dam.

The part of the ionic budget describing gains and losses in the reach between Parker and Imperial Dams (table 12, items 27-38) is based on analyses of water samples collected at approximately monthly intervals during 1962-65 from major drains in the Parker and Palo Verde Valleys and less frequently from canals and wasteways. Only the principal ionic constituents were determined for most of the samples; however, several complete analyses were made of samples from each drain. These unpublished analyses indicated rather small variations in the composition and concentration of water in the individual drains and rather marked variations from drain to drain. For the ionic budget, the 5-year average concentrations were obtained by averaging all the determined concentrations for each ion and using the complete analysis that most closely corresponded to the composition suggested by the group of ion averages. Analyses used to represent average concentrations are given in table 11.

The residual of unmeasured gains and losses (table 12, item 38) appears very reasonable considering the many diversions and returns between Parker and Imperial Dams.

\section{IONIC ACCOUNTING OF PRINCIPAL IRRIGA- TION AREAS ABOVE IMPERIAL DAM}

The salt balance of an irrigated area was defined by Scofield (1940) as the relationship between the quantity of dissolved mineral salts delivered to an area in irrigation water and the quantity removed from the area by the drainage. Scofield called an excess of removal over import a favorable salt balance and a deficiency of removal an unfavorable salt balance. The terminology of Scofield, although much used, has been opposed because an excess of deposition or withdrawal is not a balance. Nevertheless, those managing irrigation projects have become very conscious of possible salt accumulation in irrigated areas. For that reason, statements which Scofield might have termed "salt balances" are included in an accounting format (table 13).

By assembling the data from table 12 on inflow to and outflow from Parker and Palo Verde Valleys, it is possible to show the water and mineral budget of the two valleys. Item 1 , table 13 , gives the 1961-65 average annual water and ionic budget for Parker Valley that was computed by subtracting the sum of the water and ionic loads diverted from the Colorado River in water used to irrigate the valley from the water and loads returned to the river in the three principal drains. The accounting indicates leaching of common salt (sodium chloride) from the valley soils and suggests some replacement of sodium

TABLE 13.-Average annual water use and ionic burden in irrigated areas, Parker Dam to Imperial Dam, 1961-65

[Water use in acre-feet. Ionic gain $(+)$ and losses $(-)$ in thosuands of tons-equivalent]

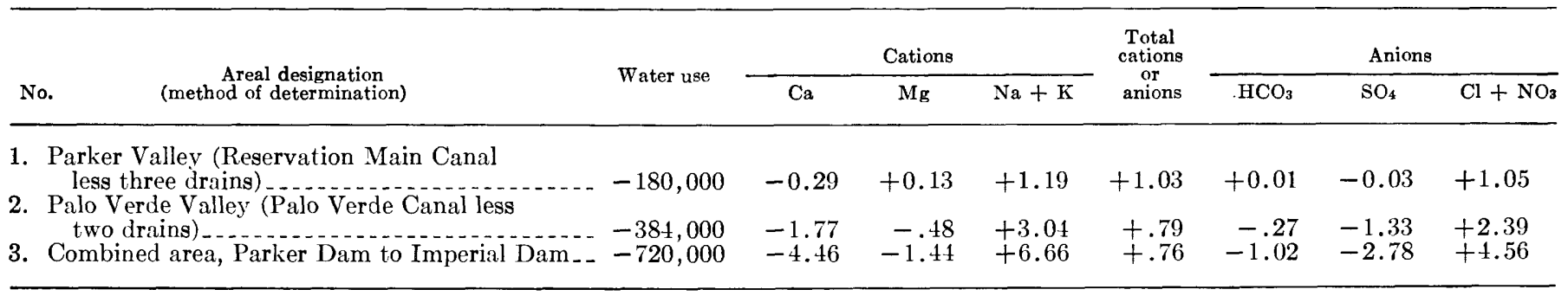


in the soils by calcium. Item 2 in the table shows the water and ionic budget for Palo Verde Valley that was obtained by subtracting the returns in two drains from diversions to the valley. The accounting suggests that some precipitation of gypsum and calcite is occurring in the valley soils and that there is loss of additional calcium from the water to the soil. The principal change in this valley, as in the Parker Valley, is a net removal of sodium chloride.

The valley budgets computed from available records are inherently inexact because of unmeasured seepage returns to the river. A combined budget for the Colorado River reach between Parker and Imperial Dams (table 13, item 3) reduces these errors. This combined budget, which is based on good streamflow and quality-of-water records during 1961-65, indicates deposition of calcite and gypsum, some base-exchange replacement of calcium by sodium, and removal of sodium chloride (probably mostly derived from leaching), but does not show where the chemical gains and losses occurred.

\section{GENERAL CHARACTERISTICS OF THE COLORADO RIVER WATER BELOW IMPERIAL DAM}

The lower Colorado became a managed river when Hoover Dam was closed, but for many years the flow of the river exceeded downstream needs. The salinity of local water supplies became a serious concern in the part of the Colorado River service area downstream from Imperial Dam only when developed needs for water became about equivalent to the flow of the river. So long as there was substantially more flow in the river than required by irrigators (the usual condition prior to the 1960's), diversion procedures and irrigation practices were developed on the basis of convenience, with little attention being paid to saline drain waters other than to remove them from farmed areas in surface drains.

Nearly all the water now (1969) reaching Im perial Dam (about 6 million acre-ft annually) is used for irrigation or public supply in the United States and Mexico. The present chemical regimen of the lower river, however, is complicated because the flow of the river is greatly depleted at the dam and because numerous drains and wasteways with differing chemical characteristics empty into it and the tributary Gila River. Continuous efforts are made to closely control both the amount and quality of the water reaching Morelos Dam, the principal Mexican diversion point.

The part of the Colorado River service area (the area receiving irrigation water from the Colorado
River; figs. 11, 12) in the United States downstream from Imperial Dam is mostly simply divided into the Yuma area (flood plain and mesas along the Colorado and Gila Rivers, west of the Gila Mountains), the Wellton-Mohawk area (Gila River flood plain and terrace, east of the Gila Mountains), and the Salton Sea area (irrigated valleys in the Salton Sea basin). For some descriptions the Yuma area is further divided into the Bard-Winterhaven Valley, in California, and the Yuma Valley, the North and South Gila Valleys, and the Yuma Mesa, in Arizona. Delivery of the irrigation water and drainage arrangements are by projects of the U.S. Bureau of Reclamation or by legally organized irrigations districts. The areas receiving Colorado River water and their canal and drainage systems are described in more detail in the companion report by Hely (1969).

Most of the Colorado River water used in the United States is diverted at Imperial Dam, but a small part, at times including most of the water used in the city of Yuma, Ariz., is diverted directly from the river downstream from the dam. This water has generally been more saline than the water at the dam.

Above the Wellton-Mohawk area the Gila River channel is nearly always dry, but at its mouth this river has a small perennial flow resulting from return flow from irrigation with Colorado River water and pumpage from drainage wells. The salinity of the water in the lower Gila River is nearly always substantially greater than that of the water in the Colorado River, and the salinity of the water in the Colorado River at Morelos Dam is more variable and nearly always considerably greater than that at Imperial Dam.

Mexico's annual entitlement to Colorado River water $(1,500,000$ acre-ft, $\mathrm{min})$ is defined by treaty to include water reaching Mexico in irrigation drain and wasteway channels. Most of this water is diverted from the Colorado River at Morelos Dam, west of Yuma, but somewhat less than 10 percent enters Mexico in a large drain and a small canal which cross the international boundary near San Luis, Ariz., south of Yuma. There is usually little flow in the Colorado River channel downstream from Morelos Dam except for seepage, small returns from three wasteways, and water deliberately bypassed around Morelos Dam through a recently constructed wastewater conveyance channel. At times there have been small diversions by pumping directly from the river below Morelos Dam, both in the United States and in Mexico. The quality of the 


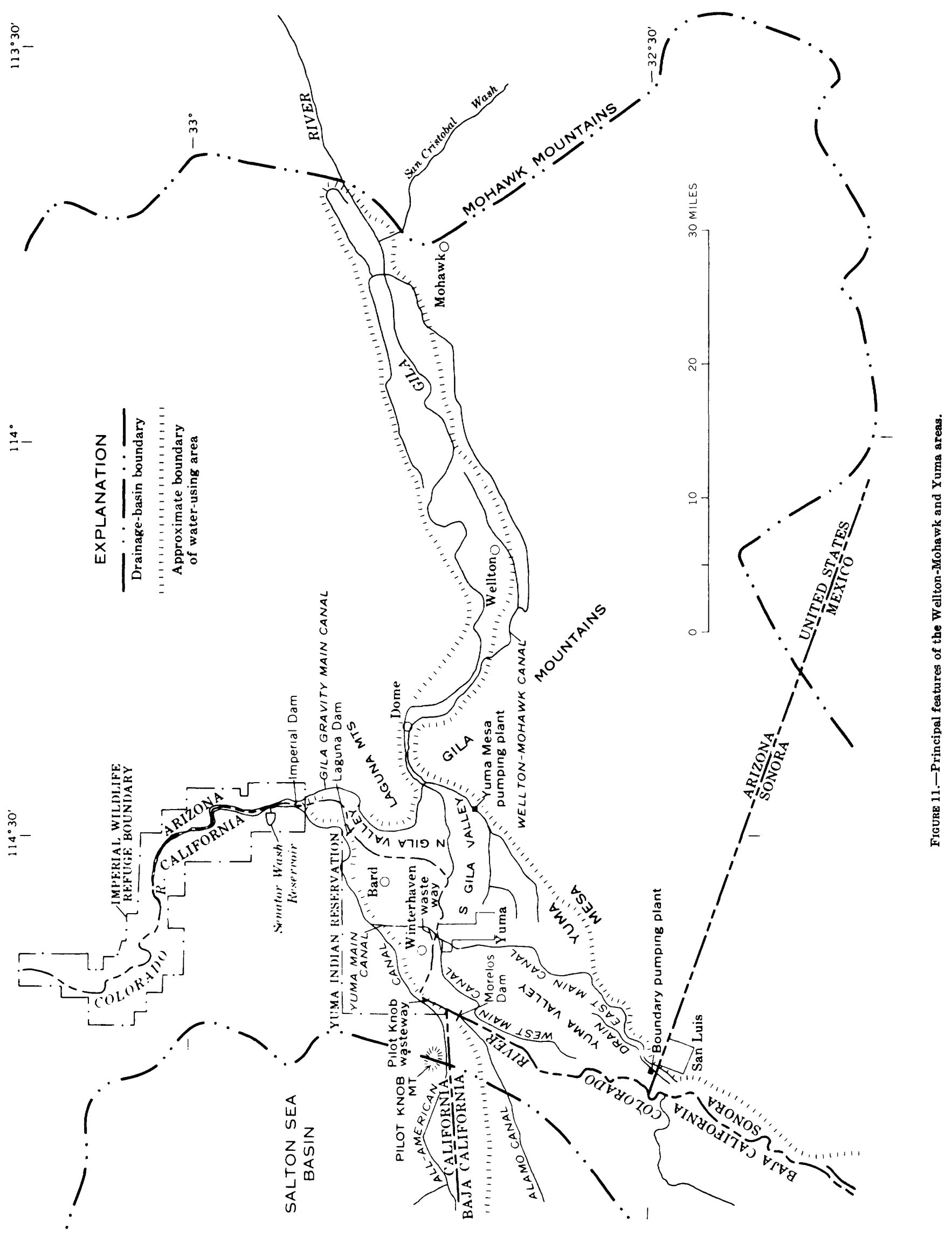




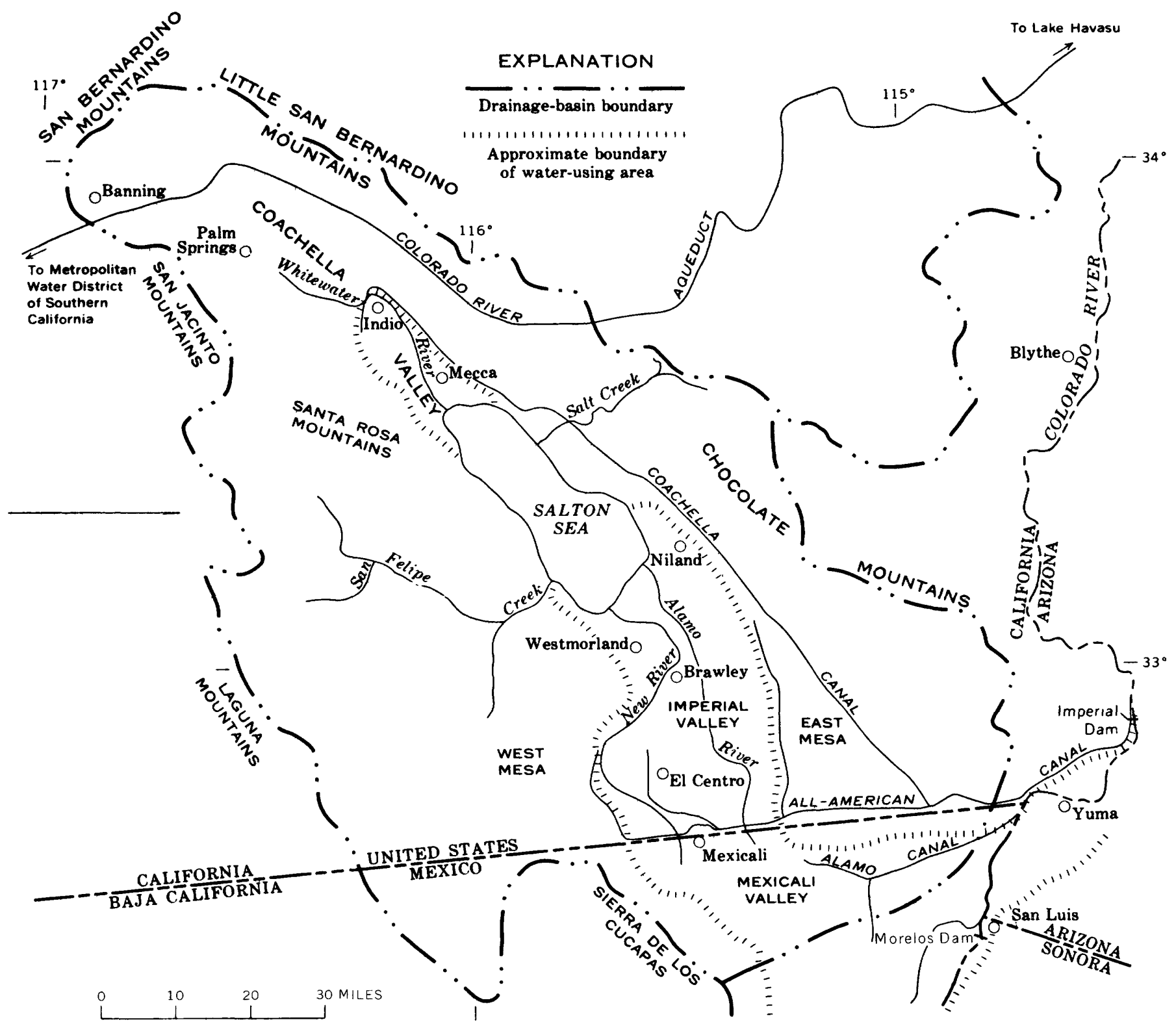

Figure 12.-Principal features of the Salton Sea area and vicinity.

water diverted for use in Mexico is quite variable, but almost all of it has higher dissolved-solids content than the water at Imperial Dam.

Pumping of ground water from large-capacity wells drilled to control water levels in a water-logged strip on the east side of Yuma Valley began in 1955 and steadily increased thereafter. Pumping from drainage wells was extended later to the South Gila Valley and the Wellton-Mohawk area. Salinity, however, did not become very troublesome until the summer of 1961, when pumping was greatly increased in the Wellton-Mohawk area; there, more than 60 wells were pumped into a newly constructed wastewater conveyance channel that extended nearly to the mouth of the Gila River. The increased pumping of saline water resulted in a large and abrupt increase in the salinity of the Colorado River water used for public supply in Yuma, Ariz., and for irrigation and public supply in Mexico. The water company supplying the city of Yuma temporarily abandoned its intake in the Colorado River and obtained water diverted at Imperial Dam. Most Mexican water users had no alternative source of public supply, and their principal source of irriga- 
tion water was affected. Consequently, control of the salinity of Colorado River water flowing to Mexico became, and has remained (to 1969), a subject of international negotiations.

Among steps taken to control salinity of water at Morelos Dam were controlled releases of water at Imperial Dam to provide better dilution, temporary cessation of pumping from some of the more saline wells in the Wellton-Mohawk area, drilling of additional wells in areas where salinity was lower so that salinity of pumped water could be controlled somewhat, and construction of additional drainage works. By the early part of 1966 , substantial control of the saline drainage had been achieved by these methods and by construction of a concrete-lined extension of the conveyance channel to a point below Morelos Dam, with provision for release of water either above or below the dam. The total number of drain wells in the Wellton-Mohawk area was then about 100.

Because of the constantly increasing pumping of saline ground water for drainage and the construction and operation of new drain channels, the chemical regimen of the Colorado River changed so much during 1961-65 that averages for the period are not particularly relevent to present or future conditions. Hence, the chemical regimen of the lower river is described for the single year 1966 rather than the 5-year period 1961-65 used to describe the river's regimen upstream from Imperial Dam.

Chemical analyses representatives of surface-water quality at representative sites on rivers, drains, and wasteways in the Yuma and Wellton-Mohawk areas during 1966 are given in table 14. (Many of the smaller drains and wasteways are not shown in figure 11 , but the areas in which they are situated are indicated. Exact locations are given in the water-supply papers of the U.S. Geological Survey and state reports in which the discharge records are published.) The table includes weighted-average concentrations, arithmetic averages, and selected analyses, depending upon the basic data available. To show progressive changes, the analyses for the Colorado River, the Gila River, and the WelltonMohawk Conveyance Channel are given in downstream order. The analyses of samples from other channels are grouped geographically.

The large number of surface drainage and waste channels emptying into the Colorado River below Imperial Dam and the Gila River complicates appraisal of surface-water quality. Discharge records are published for 28 distinct channels discharging to the rivers, as well as for river discharges at several points. Some of the drain channels have been sampled sufficiently for good generalizations about water-quality variation; others have not. River discharges have not been regularly determined at the junction of the Colorado and Gila Rivers, although daily sampling has been conducted on both rivers just above the junction. Therefore, because of the absence or paucity of data, the ensuing salinity appraisal is in part conjectural. Some of the smaller waste and drain channels are assumed to have patterns of water-quality variation similar to patterns in other nearby drains, and averages of the daily analyses for the Colorado and Gila Rivers at their

TABLE 14.-Representative analyses, in milligrams per liter, of surface water in Colorado River Basin at and below Imperial Dam, 1966 water year

\begin{tabular}{|c|c|c|c|c|c|c|c|c|c|c|c|c|}
\hline No. & Source & $\begin{array}{c}\text { Date } \\
\text { (*weighted } \\
\text { average; } \\
\text { **arithmetic } \\
\text { average) }\end{array}$ & 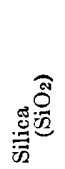 & . & 昜 & : & 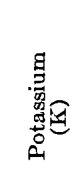 & 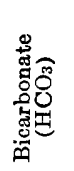 & 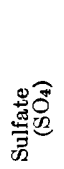 & : & 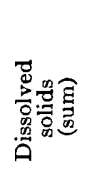 & 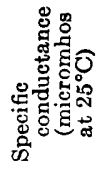 \\
\hline 1. & Colorado River at Imperial Dam.. & $1966 *$ & 9 & 100 & 34 & & & 170 & 340 & 146 & 857 & 1,410 \\
\hline & Colorado River above Gila River & $1966^{* *}$ & 12 & 106 & 40 & & & 208 & 388 & 202 & 1,050 & 1,700 \\
\hline & Colorado River at north international boundary & $1966^{*}$ & 10 & 125 & 47 & & & 203 & 396 & 339 & 1,270 & 2,140 \\
\hline & Colorado River at south international boundary & $1966^{*}$ & 20 & 223 & 91 & & & 243 & 725 & 1,120 & 3,040 & 4,810 \\
\hline & Gila River above Wellton-Mohawk area & $1966 *$ & 16 & 68 & 21 & & & 160 & 115 & 267 & 738 & 1,380 \\
\hline & Gila River at Dome. & $1966^{*}$ & 11 & 86 & 29 & & & 176 & 183 & 375 & 1,020 & 1,770 \\
\hline & Gila River at mouth & $1966^{* *}$ & 21 & 174 & 77 & & & 292 & 500 & 792 & 2,230 & 3,710 \\
\hline & Wellton-Mohawk Conveyance Channel (total) & $1966^{*}$ & 25 & 325 & 148 & & & 339 & 925 & 1,890 & 4,620 & 7,570 \\
\hline & Wastegate discharge, Mode 1 & $1966^{*}$ & 25 & 298 & 135 & & & 347 & 875 & 1,610 & 4,110 & 6,610 \\
\hline & Wastegate discharge, Mode 2 & $1966^{*}$ & 25 & 325 & 148 & & & 352 & 925 & 1,850 & 4,570 & 7,420 \\
\hline 11. & Wastegate discharge, Mode 3 & $1966 *$ & 24 & 345 & 143 & & & 320 & 975 & 2,050 & 4,950 & 7,950 \\
\hline 12. & North Gila, Drain 1 & May $13,1966 \ldots$ & 21 & 130 & 52 & & & 292 & 525 & 298 & 1,480 & 2,430 \\
\hline 13. & North Gila Bruce Church Drain & June 17,1966 & 30 & 183 & 64 & & & 408 & 575 & 252 & 1,570 & 2,330 \\
\hline 14. & South Gila pump outlet channel 3 & Mar. $29,1966 \ldots$ & 22 & 234 & 116 & & & 348 & 500 & 1,290 & 3,060 & 5,040 \\
\hline 15. & South Gila pump outlet channel 2 & Feb. 22,1966 & 19 & 190 & 84 & & & 240 & 475 & 925 & 2,350 & 4,100 \\
\hline 16. & South Gila pump outlet channel & May $13,1966 \ldots$ & 23 & 162 & 60 & & & 296 & 475 & 675 & 2,020 & 3,530 \\
\hline 17. & South Gila pump ontlet channel 4. & Nov, $2 f, 1965 \ldots$ & 23 & 338 & 150 & & & 328 & 575 & 1,860 & 3,960 & 6,790 \\
\hline 18. & Reservation Main Drain 4. & June 16,1966 & 21 & $\begin{array}{l}000 \\
127\end{array}$ & 54 & & & 280 & 412 & 230 & 1,190 & 1,890 \\
\hline 19. & East Main Canal, at international boundary & June 13,1966 & 20 & 111 & 42 & & & 204 & 300 & 398 & 1,240 & 2,160 \\
\hline 20. & Yuma Main Drain at boundary pumping plant... & June $13,1966 \ldots$ & 22 & 158 & 60 & & & 300 & 525 & 428 & 1,690 & 2,750 \\
\hline
\end{tabular}


confluence are assumed to represent discharges computed by summation of measured inflows in several upstream channels.

Some of the analyses in table 14 are probably not very representative of concentrations occurring after 1966, whereas others may reflect later conditions rather well. Thus, Colorado River water at Imperial Dam (item 1) is quite like the later weighted-average analyses in table 6 (which summarized water quality at Imperial Dam for 25 years) and is probably not greatly different from weighted averages which may be computed for this station in the next few years. In contrast, the Colorado River at the south international boundary (item 4) represents a particular pattern of flows below Morelos Dam which is unlikely to be repeated. The analysis for the Colorado River above the Gila River (item 2) reflects the effects of evapotranspiration from phreatophytic vegetation and some irrigation return flow on the relatively small release from Imperial Dam. This analysis also is similar to many analyses of Colorado River water collected at Yuma prior to the beginning of substantial pumping of drainage wells. The analysis for the Colorado River at the north international boundary (item 3 ) reflects the effort to control salinity by selective pumping of drainage wells.

The analyses listed for the Gila River also are probably unrepresentative for future concentrations. During the winter of 1965-66, floods in the Salt River basin above Phoenix resulted in storage of about 200,000 acre-feet of low-salinity water in the Painted Rock reservoir on the Gila River, about 100 miles east of Yuma. This was the first water stored in the reservoir since the dam was completed in 1959. The flood water was released slowly over several months, and much of it was dissipated in the dry river channel below the dam. At least 30,000 acrefeet of the low-salinity water, however, passed the Gila River gaging station at Dome, Ariz., near the dividing point between the Wellton-Mohawk and Yuma areas. Analyses of samples taken at Dome and upstream from the Wellton-Mohawk area were used to compute the yearly concentrations given as items 5 and 6 in table 14. The salinity of the water passing Dome was somewhat higher than that above the Wellton-Mohawk area because of small irrigation return flows draining into the river in the area.

The flow of the Gila River at its mouth (item 7, table 14) includes the flood water passing Dome, the normal drainage from irrigation entering the river between Dome and its mouth, and an unusual increment of Wellton-Mohawk drainage pumped into and released from the Wellton-Mohawk Conveyance Channel through the gate known as Mode 1. This release was required by construction activities, and it is unlikely that as much water will be released into the Gila River through this gate during future years as during 1966. Flow in the Gila River at its mouth included water discharged from three concrete-lined drainage channels in the South Gila Valley which carry only ground water pumped from drainage wells. One of the channels became operative in 1966 and therefore probably delivered somewhat less water to the river than will be usual in future.

The conveyance channel is now (1969) the main drainage discharge for the Wellton-Mohawk area, although some seepage flows resulting from irrigation still move down parts of the Gila River channel. The weighted-average concentration of all flow in the conveyance channel during 1966 is given by item 8 in table 14. The corresponding dissolved-solids concentration of water released into the Gila River through the upper gate is given as wastegate discharge, Mode 1 (item 9). Water released into the Colorado River above Morelos Dam is given as wastegate discharge, Mode 2 (item 10). Water bypassing Morelos Dam and released below it is given as wastegate discharge, Mode 3 (item 11). Although the dissolved-solids concentration of the Wellton-Mohawk drainage was always much greater than that of the Colorado River, comparison of the various weighted averages indicates that there were significant differences in the average concentrations at the various sampling points. The concentration of water pumped from the drainage wells in the Wellton-Mohawk area differs from well to well. The planned operation is for future pumping to be conducted so that the more concentrated waters will be pumped when there is the most dilution water available at Morelos Dam. Thus, the variations in weighted-average concentrations in the conveyance channel noted for 1966 may not be very representative of the concentrations for future years.

Chemical analyses selected to represent the quality of water in smaller drain channels in the Yuma area are given by items $12-20$, table 14 . They illustrate the considerable variability of water flowing into the Colorado and Gila Rivers or passing across the Mexican boundary. Items 12 and 13 are drain waters from the North Gila Valley, an area not affected by pumping from drain wells. They indicate only moderately altered Colorado River water. Items 14-17 are representative of ground waters pumped from drainage wells screened in the coarse gravel zone in the South Gila Valley. The sampling records 
show that water quality in these channels differs from time to time, depending upon which wells are being pumped. Each channel, however, has developed a consistent pattern of chemical characteristics. All these channels, like the Wellton-Mohawk Conveyance Channel, carry water in which the chloride concentration consistently exceeds the sulfate concentration.

The chemical characteristics of water in the Reservation Main Drain (item 18) are similar to those of the drains in the North Gila Valley. The water in the East Main Canal at the boundary (item 19) reflects the pumping of two or three drain wells into the residual canal flow. Some drain well water also is discharged into the Yuma Main Drain. The normal flow in this drain, however, is so large compared with the pumpage from wells that its chemical characteristics (item 20) are more similar to those of the drain water from the North Gila.

\section{IONIC BUDGETS FOR THE COLORADO RIVER BELOW IMPERIAL DAM AND GILA RIVER}

An ionic budget for the Colorado River from Imperial Dam to the south international boundary, computed for the single year 1966 from the chemical analyses summarized in table 14, is given in table 15 . This budget is based on the assumption that the chemical analyses of water from the Yuma Main Canal are representative of water in all the main canal wasteways discharging unused water to the rivers. The monthly Yuma Main Canal analyses, however, were weighted according to the corresponding monthly flows discharged at budgeted points on the canals.

The budget in table 15 is comparable with the ionic budget for the Colorado River from Lees Ferry to Imperial Dam (table 12) except that it represents average annual loads for the year 1966 only. It shows great depletions of river flows and mineral loads resulting from diversions at Imperial Dam, numerous gains from there to Morelos Dam, diversions at Morelos Dam, and the quantities in the river at the south international boundary where the Colorado River leaves the United States.

A separate ionic budget for the Gila River from above the Wellton-Mohawk area to the river's mouth for 1966 is given in table 16. As indicated by this budget the Gila River was a losing stream above Dome gaging station during 1966 and a gaining

TABLE 15.-Streamflow ionic budget of the Colorado River, Imperial Dam to south international boundary, 1966 [Streamflow in acre-feet; ionic gains $(+)$ and losses $(-)$ in thousands of tons-equivalent]

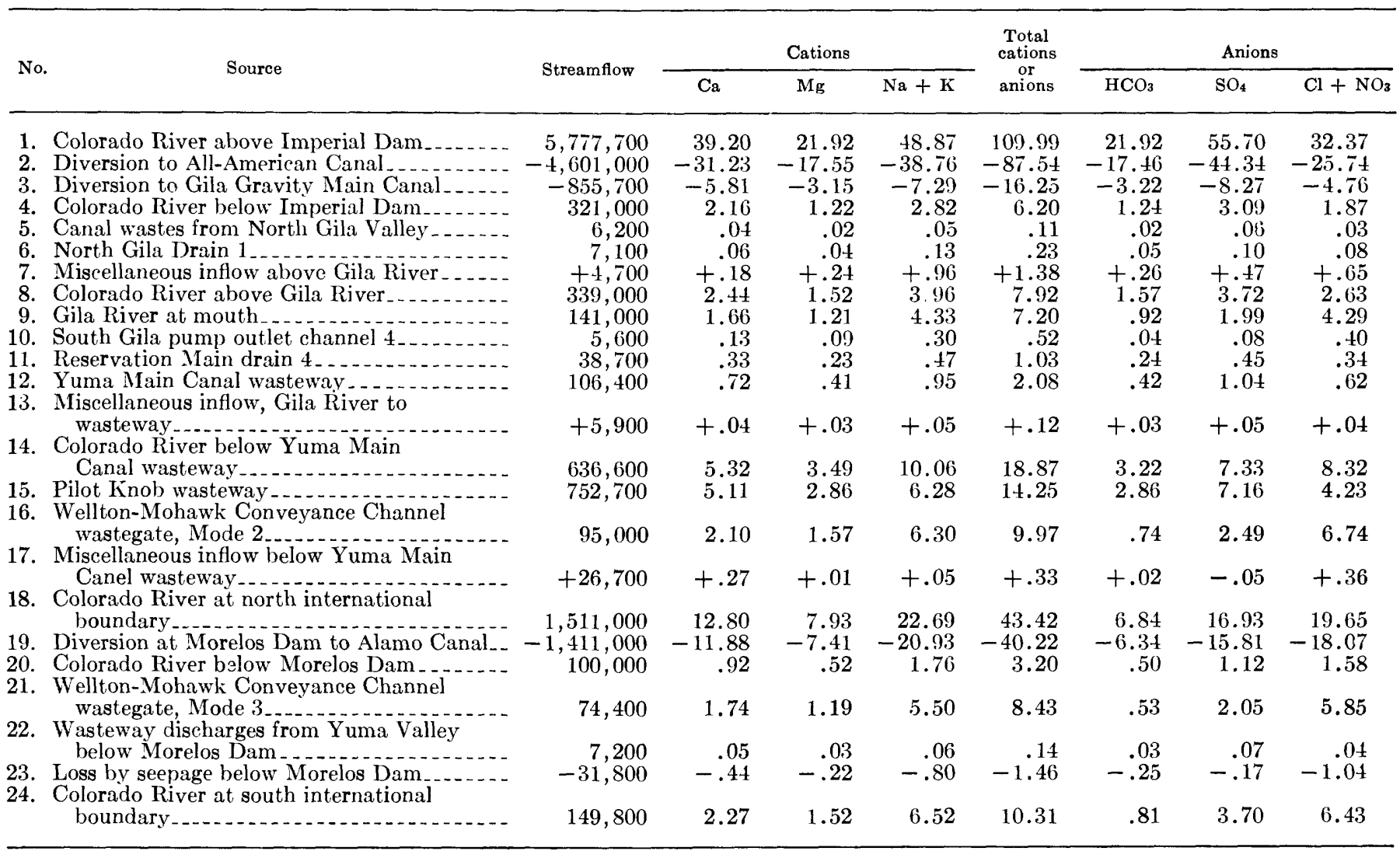


TABLE 16.-Streamflow and ionic burden of the lower Gila River, Wellton-Mohawk area to mouth, 1966

[Streamflow in acre-feet; loads in thousands of tons-equivalent]

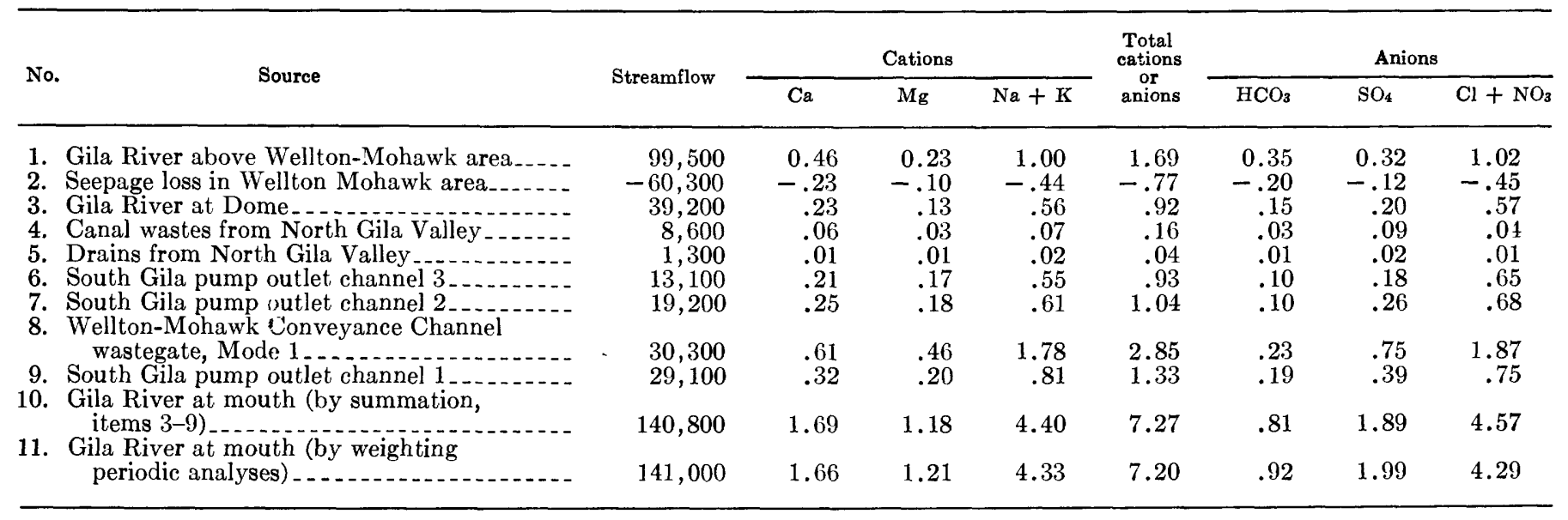

stream from Dome to its mouth. Because of unusually high flow in the Gila River above the budget area, the 1966 mineral load passing Dome is not likely to happen again except during periods of exceptional rainfall. In the Gila River budget, the sums of the increments of streamflow and ionic loads (item 10) computed for all entering flows (items 3-9) are compared with quantities computed from the chemicalquality record obtained from sampling at its mouth (item 11). The close agreement between the two differently computed loads strengthens confidence in the assumptions used in budgeting.

The largest ionic increments added to the Gila River loads during 1966 entered the river in water released from the Wellton-Mohawk Conveyance Channel through the Mode 1 gate. As this gate is not planned for use in the future, except during short periods, the future additions to Gila River ionic loads from this source are likely to be negligible. If this is true, there may be some decrease in salinity of water at the Colorado River intake for the Yuma water supply. Reduction of release through gate 1 is not likely to have any effect on the salinity of Colorado River water at Morelos Dam because water previously released through gate 1 generally will be released through gate 2 above the dam.

The complex pattern of surface diversions and return flows in this part of the lower Colorado River service area obscures the effects of the distribution and use of the river water. By selecting and rearranging items in the two budgets, however, some clarification of the ways that water developments have affected stream water quality is achieved. Thus, an inflow-outflow analysis (table 17) combining changes in areas in the Colorado River basin downstream from Imperial Dam receiving Colorado River water simplifies budget understanding. In this analysis the quantities of water and mineral ions arriving at Imperial Dam are reduced by the quantities going out of the Colorado River basin in the All-American Canal. To these adjusted quantities are added the quantities of water and mineral ions in the Gila River as it enters the Wellton-Mohawk area. The sum is a statement of the combined water and mineral supply for the United States and Mexican parts of the service area. The five outflows to Mexico are then added to give the total surface flows and ionic loads entering Mexico. The differences between the outflows to Mexico and the combination water supply constitute a statement of the draft on surface water and concurrent mineral regimen in the combined Wellton-Mohawk and Yuma areas. Negative quantities represent water use, increase of ground-water storage, and mineral deposition or storage; positive quantities represent mineral removal from the combined areas.

Obviously the net water depletion and ionic gains and losses determined according to the summary at the end of table 17 were not uniformly distributed in the irrigated areas receiving Colorado River water. By (1) computing seepage losses in the large water-supply canals and in the unlined section of the Wellton-Mohawk Conveyance Channel; (2) computing the gains or losses of water and dissolved minerals diverted to and removed from the individual irrigated sections; and (3) considering unmeasured increases in flow of the Colorado River and their mineral increments, it is possible to distribute the cains and losses as shown in table 18.

The distribution of ionic gains and losses in table 18 is related to both present and past irrigation and drainage patterns. Part of the gains in the Colorado 
TABLE 17.-Streamflow and ionic burden of inflow and outflow for combined Wellton-Mohawk and Yuma areas, 1966 [Streamflow in acre-feet; ionic loads in thousands of tons-equivalent]

\begin{tabular}{|c|c|c|c|c|c|c|c|c|c|}
\hline \multirow{2}{*}{ No. } & \multirow{2}{*}{ Measuring point or description } & \multirow{2}{*}{ Streamflow } & \multicolumn{3}{|c|}{ Cations } & \multirow{2}{*}{$\begin{array}{l}\text { Total } \\
\text { cations } \\
\text { or } \\
\text { anions }\end{array}$} & \multicolumn{3}{|c|}{ Anions } \\
\hline & & & $\mathrm{Ca}$ & $\mathrm{Mg}$ & $\mathrm{Na}+\mathrm{K}$ & & $\mathrm{HCO}_{3}$ & $\mathrm{SO}_{4}$ & $\mathrm{Cl}+\mathrm{NO}_{3}$ \\
\hline & $\begin{array}{l}\text { Colorado River at Imperial Dam } \\
\text { All-American Canal below Pilot Knob (loss) } \\
\text { Net supply from Colorado River } \\
\text { Gila River flow into Wellton-Mohawk area.- }\end{array}$ & $\begin{array}{r}5,777,700 \\
-3,299,000 \\
2,478,700 \\
99,500\end{array}$ & $\begin{array}{r}39.20 \\
-22.39 \\
16.81 \\
.46\end{array}$ & $\begin{array}{r}21.92 \\
-12.52 \\
9.40 \\
.23\end{array}$ & $\begin{array}{r}48.87 \\
-27.90 \\
20.97 \\
1.00\end{array}$ & $\begin{array}{r}109.99 \\
-62.81 \\
47.18 \\
1.69\end{array}$ & $\begin{array}{r}21.92 \\
-12.52 \\
9.40 \\
.35\end{array}$ & $\begin{array}{r}55.70 \\
-31.81 \\
23.89 \\
.32\end{array}$ & $\begin{array}{r}32.37 \\
-18.48 \\
13.89 \\
1.02\end{array}$ \\
\hline & $\begin{array}{l}\text { Total surface water supply and } \\
\text { contained minerals.... }\end{array}$ & $2,578,200$ & 17.27 & 9.63 & 21.97 & 48.87 & 9.75 & 24.21 & 14.91 \\
\hline & \multicolumn{9}{|c|}{ Outflows in surface channels } \\
\hline \multirow{3}{*}{\multicolumn{2}{|c|}{$\begin{array}{l}\text { 5. Colorado River at north international } \\
\text { boundary } \\
\text { 6. Wellton-Mohawk drainage discharge } \\
\text { below Morelos Dam through Mode 3. } \\
\text { 7. Three wasteways from Yuma Valley } \\
\text { entering river below Morelos Dam } \\
\text { 8. East Main Canal wasteway discharge } \\
\quad \text { across international boundary } \\
\text { 9. Yuma Main Drain discharge at } \\
\text { boundary pumping plant }\end{array}$}} & $1,511,000$ & 12.80 & 7.93 & 22.69 & 43.42 & 6.84 & 16.93 & 19.65 \\
\hline & & 5,000 & .04 & .02 & .08 & .14 & .02 & .01 & .08 \\
\hline & & 123,100 & 1.32 & .83 & 2.53 & 4.68 & .83 & 1.83 & 2.02 \\
\hline & $\begin{array}{l}\text { Total surface outflow and } \\
\text { contained minerals. }\end{array}$ & $1,721,000$ & 15.95 & 10.00 & 30.86 & 56.81 & 8.25 & 20.92 & 27.64 \\
\hline
\end{tabular}

Areal change

10. Outflow-inflow (plus $(+)=$ gain;

minus $(-)=$ loss $) \ldots$

River undoubtedly resulted from seepage from the parallel sections of the Gila Gravity and All-American Canals. Induced seepage of Colorado River water probably also occurs in the areas adjacent to the river which are irrigated by pumped ground water. Thus, ground-water pumpage in the Island, an area within a former river meander not served by surfacewater canals, may account for the apparent mineral retention in the Bard-Winterhaven and North Gila Valleys. Mineral removal is indicated for the Wellton-Mohawk and South Gila Valleys, the two areas showing minimum surface drainage, a long history of former ground-water irrigation, and present drainage from wells. The seepage loss from the Wellton-Mohawk Conveyance Channel probably moved towards the drainage wells in the South Gila Valley. Irrigation of the undrained Yuma mesa also accounts for movement of water to the South Gila Valley, the only area from which more water was pumped than was applied for irrigation.

The relatively large removal of minerals from the South Gila Valley and Wellton-Mohawk area cannot be expected to continue at the present rate indefi- nitely, and it is probable that the outflow of minerals from these areas will slowly decline.

\section{QUALITY OF SURFACE WATER IN THE SALTON SEA BASIN IN CALIFORNIA}

The Imperial Valley and part of the Coachella Valley in California depend almost entirely on water diverted to them from the Colorado River through the All-American Canal and its branches. Water in the distributary canals in the two valleys has been found by sampling surveys to have practically the same salinity as the Colorado River water diverted at Imperial Dam. Hence, so long as the quality of diverted water is suitable for irrigation and enough is applied to prevent accumulation of salts in the soil, salinity problems in the two valleys will be limited to those resulting from application of river water to naturally saline soils or soils made saline by artificially high water tables that cause concentration of salts in the capillary fringe.

The natural saline-mineral content of soils and subsoils in parts of both the Imperial and Coachella Valleys was high before irrigation began. Soils in some areas were too saline for successful irrigation 
TABLE 18.-Distribution of surface-water and dissolved-mineral gains (十) and losses (-) for combined Wellton-Mohawk and Yuma areas, 1966

[Streamflow in acre-feet; dissolved minerals in thousands of tons-equivalent]

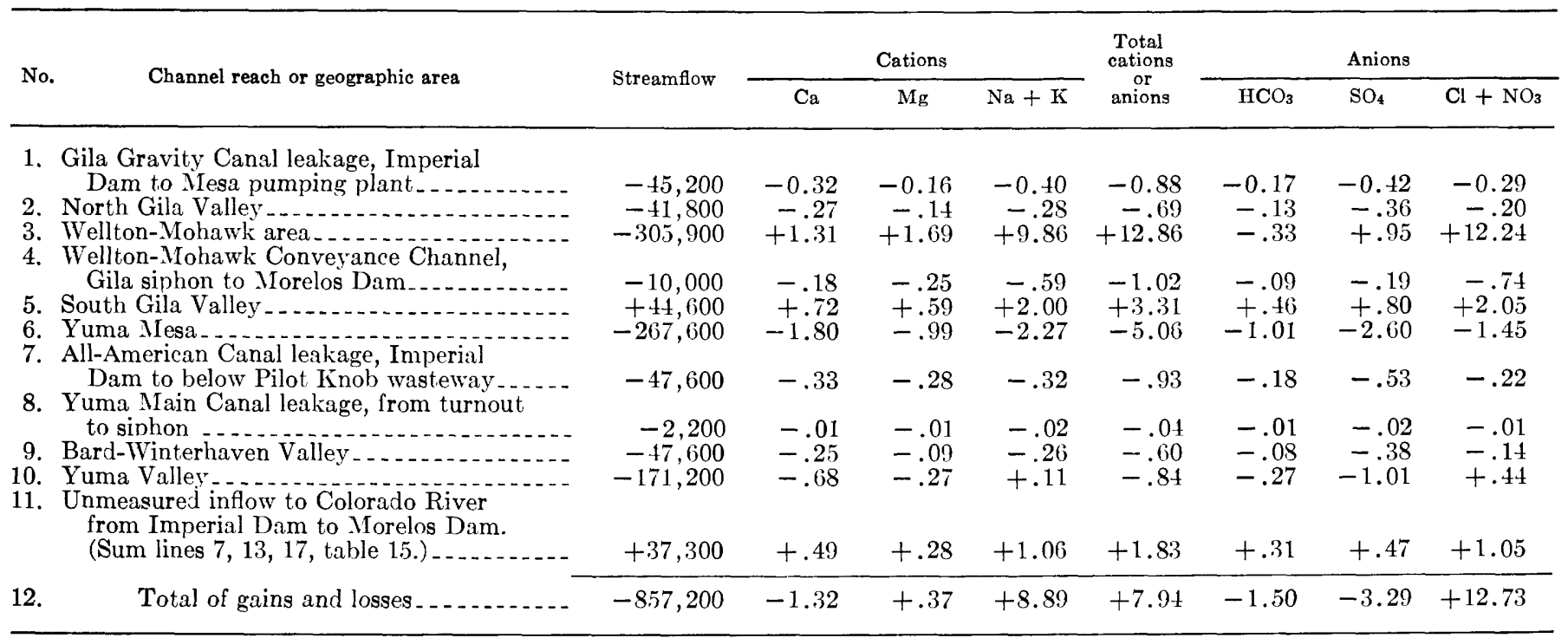

until they were leached. Early irrigation, particularly in the Imperial Valley, was mostly carried on without any provision for drainage except that which occurred through natural channels. As the farmland was all nearly level and had little natural drainage, some waterlogging soon occurred, and consequently the acreage of saline soils began to increase. Constructions of drainage systems to remedy the situation in the Imperial Valley began about 1925 . Drainage systems have since been expanded to cover most of the irrigated portions of both valleys. Although considerable salt was dissolved from its bed, much of the salt content of the Salton Sea (Hely and others, 1966) is believed to have originated from minerals leached from the irrigated soils of the two valleys, and a lesser amount was derived from the water diverted from the Colorado River.

The Imperial Irrigation District has long been concerned about salt accumulation in Imperial Valley. The present quantity of drainage from the valley is about $11 / 4$ million acre-feet per year. The district for many years has obtained approximately monthly analyses of water samples collected from the Alamo and New Rivers at the Mexican border and near their mouths, and also occasional analyses of samples from some of the 30 or more artificial drain channels which flow directly into the Salton Sea. Since 1943 the Imperial Irrigation District has computed annual mineral budgets by using its analyses and averages representing the monthly composition of All-American Canal water. According to the district's computations, mineral salts accumulated in the valley through 1948 , but since then the quantities of dissolved mineral salts leaving the valley in drain water have exceeded the quantities entering the canal water.

The salinity of water flowing into the Salton Sea from the Alamo and New Rivers varies depending on the proportions of canal water and drainage water in each of the rivers. A very small part of the flow in the Alamo River and a much larger part of the flow in the New River is drain water from the irrigated part of the Salton Sea basin in Mexico, generally referred to as the Mexicali Valley. Some of each river's flow is canal water spilled into the river or a drain, some is wastewater diverted from the lower ends of flooded fields following irrigation, and some is seepage entering the drains from fields. As the relative quantities continually change, the salinity of the two rivers fluctuates rather erratically and without much relation to season. The New River water, however, is almost always considerably more saline than the Alamo River water.

Partial chemical analyses of monthly samples obtained from Alamo and New Rivers and analyses of less frequent samples obtained from selected drains in the valley during 1961-65 indicate that it would not be possible to define a mineral budget for the Imperial Valley without much more frequent sampling and more complete chemical analyses. Consequently, a mineral budget for the Imperial Valley is not included in this report.

Coachella Valley, unlike Imperial Valley, is underlain by productive aquifers containing water of rela- 
tively low salinity. In 1948, when importation of Colorado River water to Coachella Valley began, about 20,000 acres were being irrigated by pumping from wells, and extensive lowering of the groundwater levels had occurred. As Colorado River water became available and irrigated acreage expanded greatly, river water replaced much of the ground water previously used for irrigation, and thereafter ground-water levels in irrigated areas began to rise. Recently, about 60,000 acres in the valley have been irrigated with Colorado River water. Some of the water brought in by canal may still be going into ground-water storage, but in most of the irrigated area water levels have risen until surface drain channels now flow continuously.

The Whitewater River channel is the major natural drainage for the Coachella Valley. Prior to the importation of Colorado River water, the Whitewater River channel was dry most of the time, but during recent years the river has had perennial flow averaging a little more than 100 cubic feet per second. In addition to the river, there are 20 artificial channels, some of which flow continuously and some intermittently, that empty directly into the Salton Sea. About 60 percent of the drainage from Coachella Valley enters the sea through Whitewater River.

Approximately monthly samples of water from the Whitewater River water were analyzed at Yuma during 1962-65. Unfortunately the drains were not systematically sampled at that time, and only a few partial analyses of the drain water were made. Although the limited data suggest that the water in the drains is similar to that in the river, a reliable ionic budget for the Coachella Valley cannot be computed from the chemical data. Rough computations for 1962 and 1963, however, suggest that more chloride left the valley than entered in the canal water and that the quantities of sulfate entering and leaving were nearly equal.

There is no perennial flow from nonirrigated areas into the Salton Sea, except for seepage from Coachella Canal that enters via Salt Creek. Both Salt Creek, which enters the sea on the northeast side, and San Felipe Creek, which enters it on the southwest side, drain large areas and sometimes for a few hours discharge large volumes of water that is low in mineral content. This water, however, is not much of an asset because there is no practical way of using it before it enters the sea.

Analyses of water samples collected by the Geological Survey from the Alamo, New, and Whitewater Rivers selected to be representative of high and low concentrations regularly observed are given in table 19. Although the analyses do not represent maximums and minimums they are probably within about 20-25 percent of usual annual extremes. Each pair of analyses is a general measure of the salinity characteristics of the sampled river at the point of sampling.

Each river discharging to the Salton Sea has its own characteristic salinity pattern. Thus, the Alamo River water characteristically contains more sulfate than chloride at the Mexican boundary, and the relative proportion of chloride to sulfate increases towards its mouth. The water flowing from Mexico in the New River is always high in chloride relative to sulfate, and although the proportion of chloride to sulfate decreases downstream, the chloride remains dominant to the river's mouth. The Whitewater River water generally contains about twice as much sulfate as chloride. Sodium is the principal cation in the water in all three rivers. The analytical records suggest that some salvage of less-saline inflows to the Alamo and Whitewater Rivers might be practicable but that New River water has a much smaller salvage poten-

\begin{tabular}{|c|c|c|c|c|c|c|c|c|c|c|c|c|}
\hline No. & Source & 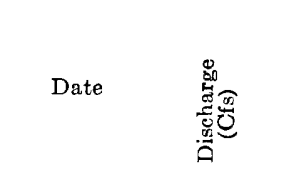 & 令 & 总 & 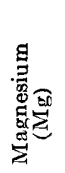 & 韋芯 & 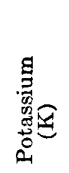 & 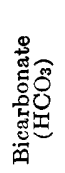 & 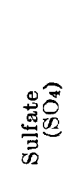 & 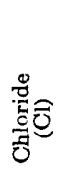 & 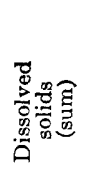 & 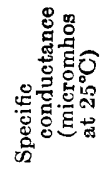 \\
\hline $\begin{array}{l}1 . \\
2 . \\
3 . \\
4 . \\
5 . \\
6 . \\
7 . \\
8 . \\
9 . \\
10 .\end{array}$ & $\begin{array}{l}\text { Alamo River at international boundary... } \\
\text { Alamo River at international boundary.. } \\
\text { Alamo River near Niland. } \\
\text { Alamo River near Niland } \\
\text { New River at international boundary. } \\
\text { New River at international boundary. } \\
\text { New River near Westmoreland. } \\
\text { New River near Westmoreland } \\
\text { Whitewater River near Mecca } \\
\text { Whitewater River near Mecca. }\end{array}$ & 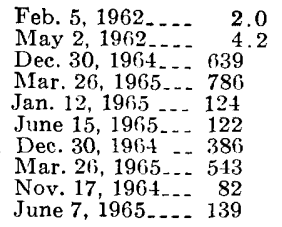 & $\begin{array}{l}13 \\
14 \\
13 \\
10 \\
25 \\
22 \\
20 \\
14 \\
18 \\
18\end{array}$ & $\begin{array}{l}199 \\
172 \\
250 \\
230 \\
284 \\
266 \\
250 \\
238 \\
166 \\
170\end{array}$ & $\begin{array}{r}108 \\
76 \\
160 \\
108 \\
93 \\
126 \\
123 \\
108 \\
51 \\
44\end{array}$ & $\begin{array}{l}\text { 1, } \\
\text { 1, }\end{array}$ & & $\begin{array}{l}311 \\
288 \\
254 \\
224 \\
260 \\
240 \\
268 \\
256 \\
336 \\
336\end{array}$ & $\begin{array}{r}1,000 \\
675 \\
975 \\
825 \\
675 \\
750 \\
850 \\
750 \\
950 \\
825\end{array}$ & $\begin{array}{r}690 \\
455 \\
1,160 \\
833 \\
2,560 \\
2,190 \\
1,750 \\
1,310 \\
472 \\
435\end{array}$ & $\begin{array}{l}2,490 \\
1,910 \\
3,410 \\
2,670 \\
5,350 \\
4,800 \\
4,250 \\
3,380 \\
2,420 \\
2,190\end{array}$ & $\begin{array}{l}4,150 \\
3,200 \\
5,530 \\
4,180 \\
9,000 \\
7,940 \\
7,010 \\
5,430 \\
3,670 \\
3,410\end{array}$ \\
\hline
\end{tabular}


tial. Salvage of water from Alamo or New Rivers would be chiefly a matter of recovering spilled canal water or reducing the amount of spill. Hence, quality of water already in the river may be unimportant for salvage operations. Moreover, any water-salvage operations would tend to reduce inflow to the Salton Sea and result in reduction, or perhaps early loss, of its recreational value because of increased salinity.

Such adverse effects might, however, be counteracted by proposed regulation of the volume and salinity of the sea.

\section{SUMMARY OF CONCLUSIONS}

The study of the chemical regimen of the lower Colorado River warrants the following general conclusions :

1. Under natural (virgin) conditions both the composition and concentration of water in the Colorado River below Lees Ferry, Ariz., varied both seasonally and annually, but probably did not substantially change downstream.

2. During the period 1926-62 (prior to closure of Glen Canyon Dam), the chemical regimen of the Colorado River at Grand Canyon and upstream, although probably somewhat different from the virgin regimen, was relatively stable. There may, however, have been small increases in average mineral concentrations, particularly towards the end of the period, caused by construction of reservoirs, increased irrigation, and increased out-of-basin diversions in headwater areas.

3. Most of the mineral burden of the Colorado River, like most of its flow, originates in the Upper Basin.

4. Blue Springs, near the mouth of the Little Colorado River, add the largest individual increment to the mineral burden of the Colorado River below compact point and above Imperial Dam. This increment, which is nearly constant because of the constancy of spring flow, consists mainly of sodium chloride (common salt).

5. Virgin River, although its annual flow is highly variable, generally contributes the second largest increment to the mineral burden between compact point and Imperial Dam. This variable increment consists mainly of gypsum (calcium sulfate), but.includes a considerable amount of common salt.

6. The other tributaries between compact point and Imperial Dam add only minor increments to the Colorado River's mineral burden.
7. The natural fluctuations in the dissolved-mineral concentrations in the Colorado River water have been greatly reduced as a result of construction of storage reservoirs in which floodflows and low flows mix, but they have not been eliminated.

8. Average concentrations of dissolved minerals in Colorado River water downstream from Lake Mead have been increased as a result of evaporation from the lake surface and solution from its bed, but these increases have been partly offset by precipitation of calcium carbonate in the body of the lake.

9. The amount of solution from the bed of Lake Mead appears to be slowly decreasing.

10. There is no evidence of appreciable solution of minerals from beds of Lakes Mohave and Havasu.

11. The effects of the recently constructed storage reservoirs above compact point on salinity of water below that point are still uncertain, but it appears likely that the mineral concentrations in the lower river will become temporarily stabilized at somewhat lower levels than those which prevailed during 1965. Additional upstream storage and irrigation projects now proposed (1969), however, will tend to increase the mineral concentration when in operation.

12. Increasing yearly diversions of Colorado River water out of the basin through the Colorado River aqueduct have contributed to the recent increases in salinity of water at Imperial Dam by reducing the flow available to dilute the relatively saline irrigation return flows.

13. Leaching of newly cultivated lands in Parker and Palo Verde Valleys have also been principal causes of higher concentrations at Imperial Dam.

14. The salinity of water in the Colorado River at Imperial Dam has increased moderately in recent years, but it is still satisfactory for public supply and for continued irrigation if provision is made to prevent accumulation of salts in the soil.

15. The chemical characteristics of water in the Colorado River downstream from Imperial Dam and in the tributary Gila River below the Wellton-Mohawk area are erratically variable and depend upon the volumes and concentrations of irrigation return flows from many sources, including ground water pumped into drain channels to control water levels. 
16. Mineral-budget computations indicate that harmful salt quantities are not now accumulating in the parts of the Colorado River basin in the United States served with Colorado River water.

17. Continued control of pumping of saline ground water will be necessary if the quality of Colorado River water diverted at Morelos Dam is to be maintained at or near its present level.

18. Under present irrigation and drainage arrangements probably no harmful salt quantities are accumulating in the parts of the Imperial and Coachella Valleys irrigated with Colorado River water.

19. Water-management practices to prevent unused canal water from entering streams draining to the Salton Sea might contribute to the available supply of water in the Imperial and Coachella Valleys. If the sea remains unregulated, however, any substantial reduction of flow to the sea would tend to reduce its volume, raise its salinity, and reduce its recreational value.

\section{REFERENCES}

Bliss, J. H., 1965, Discussion of Proc. Paper 4244-“Future quantity and quality of Colorado River water" by R. A. Hill: Am. Soc. Civil Engineers Proc., Jour. Irrigation and Drainage Divi., v. 91 , Dec., p. 82-86.

Hely, A. G., 1969, Lower Colorado River water supply-its magnitude and distribution: U.S. Geol. Survey Prof. Paper 486-D, $54 \mathrm{p}$.

Hely, A. G., Hughes, G. H., and Irelan, Burdge, 1966, Hydrologic regimen of Salton Sea, California: U.S. Geol. Survey Prof. Paper 486-C., 32 p.

Hill, R. A., 1965, Future quantity and quality of Colorado River water. Am. Soc. Civil Engineers Proc., Jour. Irrigation and Drainage Div. v. 91, March, p. 17-30.

Howard, C. S., 1955, Quality of water of the Colorado River, 1925-40: U.S. Geol. Survey open-file rept., $103 \mathrm{p}$. 1960 , Chemistry of the Water, chap. L in Comprehensive survey of sedimentation in Lake Mead, 1948-49: U.S. Geol. Survey Prof. Paper 295, p. 115-124.

Iorns, W. V., Hembree, C. H., and Oakland, C. L., 1965, Water resources of the Upper Colorado River Basin-Technical report: U.S. Geol. Survey Prof. Paper 441, 370 p.

Johnson, P. W., and Sanderson, R. B., 1968, Spring flow in the Colorado River-Lees Ferry to Lake Mead, Arizona: Arizona State Land Dept., Water Resources Rept. 34.

Scofield, C. S., 1940, Salt balance in irrigation areas: Jour. Agriculture Research, v. 61, p. 17-39. 